\title{
Zirconium-bearing accessory minerals in UK Paleogene granites: textural, compositional, and paragenetic relationships
}

\author{
Harvey E. Belkin ${ }^{1}$ and Ray Macdonald ${ }^{2,3}$ \\ ${ }^{1}$ U.S. Geological Survey, 11142 Forest Edge Drive, Reston, VA 20190-4026, USA \\ ${ }^{2}$ IGMiP Faculty of Geology, University of Warsaw, 02-089 Warsaw, Poland \\ ${ }^{3}$ Environment Centre, Lancaster University, Lancaster LA1 4YQ, UK \\ Correspondence: Harvey E. Belkin (harveybelkin@gmail.com)
}

Received: 5 May 2021 - Revised: 1 August 2021 - Accepted: 19 August 2021 - Published: 23 September 2021

\begin{abstract}
The mineral occurrences, parageneses, textures, and compositions of Zr-bearing accessory minerals in a suite of UK Paleogene granites from Scotland and Northern Ireland are described. Baddeleyite, zirconolite, and zircon, in that sequence, formed in hornblende + biotite granites (type 1) and hedenbergite-fayalite granites (type 2). The peralkaline microgranite (type 3) of Ailsa Craig contains zircon, dalyite, a eudialyte-group mineral, a fibrous phase which is possibly lemoynite, and Zr-bearing aegirine. Hydrothermal zircon is also present in all three granite types and documents the transition from a silicate-melt environment to an incompatible elementrich aqueous-dominated fluid. No textures indicative of inherited zircon were observed. The minerals crystallized in stages from magmatic through late-magmatic to hydrothermal. The zirconolite and eudialyte-group mineral are notably Y+REE-rich (REE signifies rare earth element). The crystallization sequence of the minerals may have been related to the activities of $\mathrm{Si}$ and $\mathrm{Ca}$, to melt peralkalinity, and to local disequilibrium.
\end{abstract}

\section{Introduction}

Zr-bearing accessory minerals form over a very large $P-T$ (pressure and temperature) range and in a wide variety of lithologies. The stability of these minerals relative to their host rock compositions and to other $\mathrm{Zr}$-bearing phases is complex and variable (e.g., Marks et al., 2011; Andersen et al., 2013). Relatively little is known of the factors controlling the distribution of the phases, and the textural relationships between them are often poorly documented. Critical parameters in determining which phase will form include wholerock composition and the $\mathrm{Si}$ and $\mathrm{Ca}$ activities. The $\mathrm{Zr}$ silicates are also prone to being altered by hydrothermal processes, commonly being replaced by other $\mathrm{Zr}$ silicates (e.g., Wu et al., 2015).

Attempting to understand the controls over mineral stability is particularly valuable in studies of specific igneous complexes, which can be taken as quasi-closed systems. Several studies have traced the textural and compositional variations in $\mathrm{Zr}$-bearing minerals during the evolution of specific silica-oversaturated alkaline complexes, including Birkett et al. (1992), Kynicky et al. (2011), Estrade et al. (2014, 2018), and Sarangua et al. (2019). In this paper, we report on the occurrence of Zr-bearing accessory minerals in some UK Paleogene granites.

In previous studies of UK Paleogene granites, zircon $\left(\mathrm{ZrSiO}_{4}\right)$ has been recorded optically in several of the granites, e.g., the Beinn Dearg Mhor Epigranite, the Marsco Epigranite, the Glas Bhein Mhor Epigranite (Bell, 1966), and the Glamaig Epigranite (Thompson, 1969). Zirconolite $\left(\mathrm{CaZrTi}_{2} \mathrm{O}_{7}\right.$; referred to as zirkelite) has been reported only in a pegmatitic pod from the island of St. Kilda (Harding et al., 1982; Fowler and Williams, 1986). The type locality of bazirite $\left(\mathrm{BaZrSi}_{3} \mathrm{O}_{8}\right)$ is Rockall Island, where it occurs in an aegirine-riebeckite granite (Young et al., 1978). Elpidite $\left(\mathrm{Na}_{2} \mathrm{ZrSi}_{6} \mathrm{O}_{15} \cdot 3 \mathrm{H}_{2} \mathrm{O}\right)$ and a eudialyte-group mineral $\left(\mathrm{Na}_{15} \mathrm{Ca}_{6}\left(\mathrm{Fe}^{2+}, \mathrm{Mn}^{2+}\right)_{3} \mathrm{Zr}_{3}(\mathrm{Si}, \mathrm{Nb})\left(\mathrm{Si}_{25} \mathrm{O}_{73}\right)\left(\mathrm{O}, \mathrm{OH}, \mathrm{H}_{2} \mathrm{O}\right)_{3}\right.$ $\left.(\mathrm{Cl}, \mathrm{OH})_{2}\right)$ have been recorded from Rockall Island (Young et al., 1978), and eudialyte is also known from the Carlingford Complex, Northern Ireland (Nockolds, 1950). 
No attempt has yet been made, however, to examine the compositional ranges of the minerals or to see them as a paragenetic sequence. The specific aims of the present study are (1) to document more fully the occurrence of Zr-bearing minerals in a representative suite of the Paleogene granites; (2) to relate the occurrences and chemical compositions to the compositions of the host rocks, although this goal is limited by the lack of modern geochemical data for many of the granites; (3) to determine the crystallization sequence of the Zr-bearing phases in the granites and to attempt to define the controlling factors; and (4) to report on the occurrence of dalyite (the first record in the UK), a eudialyte-group mineral and possible lemoynite in the Ailsa Craig microgranite.

\section{Geological setting of the UK Paleogene granites}

During the Paleogene Epoch, the so-called Iceland plume caused thermal uplift over an area some $2000 \mathrm{~km}$ across, stretching from northern Norway in the north to Scotland in the south. The resultant igneous rocks constitute the North Atlantic Igneous Superprovince and have a volume of 6$10 \times 10^{6} \mathrm{~km}^{3}$. The British section of the superprovince, the Paleogene Hebridean Igneous Province (Emeleus and Bell, 2005), consists of igneous centers exposed along the west coast of Scotland and in Northern Ireland and as several submerged bodies. The centers consist of lava piles, intrusive central complexes, and sets of linear and radial dike swarms. The central complexes contain a wide range of rock types, including peridotite, olivine gabbro, granites, and minor volumes of rocks with intermediate compositions. This report concerns granitic rocks from six complexes (Fig. 1). The ages of the granites are in the range $58 \pm 1 \mathrm{Ma}$ (Emeleus and Bell, 2005). The samples used here are a subset of those used in studies of minerals of the chevkinite group (Macdonald et al., 2013a) and apatite supergroup (Macdonald et al., 2013b) (Table 1).

The granites can be broadly grouped into three types on the basis of their ferromagnesian mineral assemblages (Bell, 1982): type 1, biotite \pm amphibole; type 2, hedenbergitefayalitic olivine; and type 3, alkali amphibole. The allocation of the granites into the three lithological types is given in Table 1. Although the intrusions are invariably referred to as granites in the literature, the usage followed here, they vary petrographically from alkali-feldspar granites to potassic adamellites (e.g., the Glamaig Granite; Table 1) (Thompson, 1983). The granites range from metaluminous to peralkaline, the mineralogical differences being reflected in the geochemical characteristics; the average peralkalinity indices (PIs; mol. $\left.\left(\mathrm{Na}_{2} \mathrm{O}+\mathrm{K}_{2} \mathrm{O}\right) / \mathrm{Al}_{2} \mathrm{O}_{3}\right)$ in types 1,2 , and 3 are $0.88,0.95$, and 1.05 , respectively (Bell, 1982). It may be noted that the most peralkaline of the Paleogene granites is Rockall Island, with a PI > 1.7 (Hawkes et al., 1975); the granite almost certainly crystallized from a pantelleritic magma.

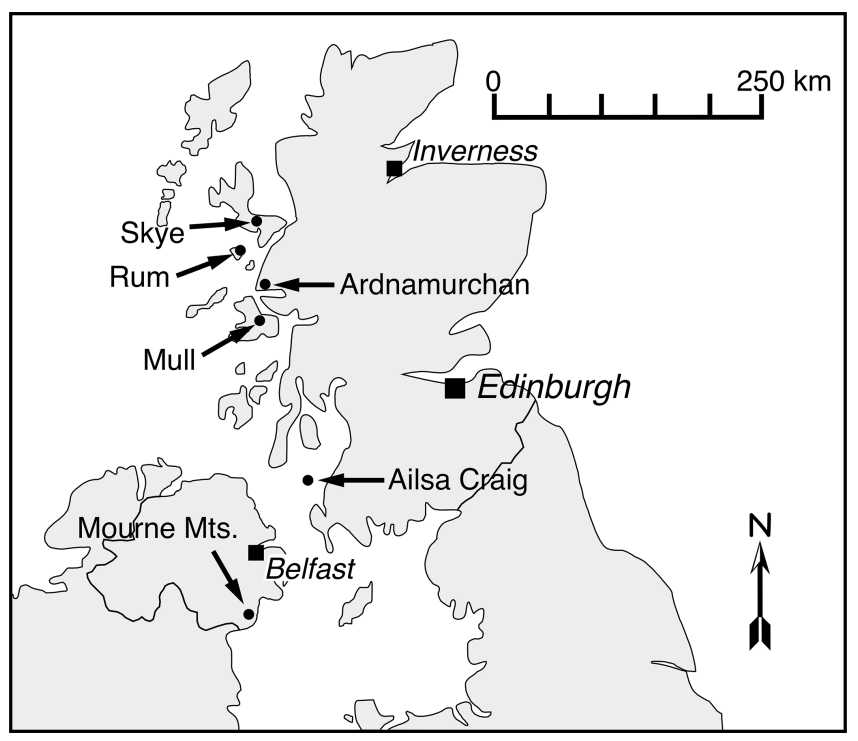

Figure 1. Location of Paleogene granitic bodies studied here. Detailed geological maps of the bodies may be found in Emeleus and Bell (2005). The samples used here are a subset of those used in studies of minerals of the chevkinite group (Macdonald et al., 2013a) and apatite supergroup (Macdonald et al., 2013b) (Table 1).

\section{Conditions of formation of the granites}

There are several difficulties in estimating the $P, T$, and $f \mathrm{O}_{2}$ conditions under which the granites crystallized. For example, the feldspars are commonly exsolved, albitized, or hydrothermally altered, and FeTi oxides are exsolved and/or oxidized. Macdonald et al. (2013b) used the apatite saturation temperature models of Harrison and Watson (1984) and Piccoli and Candela (2002) for the metaluminous granites (types 1 and 2) to suggest that they crystallized in the range $772-900{ }^{\circ} \mathrm{C}$. These temperatures are broadly in line with liquidus temperatures determined experimentally by Thompson (1983) for two Skye granites: $910-930^{\circ} \mathrm{C}$ for the Glamaig Granite and $752^{\circ} \mathrm{C}$ for the Southern Porphyritic Felsite. On the basis of oxygen isotope data, Ferry (1985) estimated that the initial stages of crystallization of the Beinn an Dubhaich Granite (type 1) occurred at $740-800^{\circ} \mathrm{C}$, with latestage crystallization at $660-700^{\circ} \mathrm{C}$. Thompson (1983) suggested that the Skye granites crystallized at $p \mathrm{H}_{2} \mathrm{O}<1 \mathrm{~kb}$, in keeping with geological evidence that they were shallow intrusions (Thompson, 1969; Emeleus and Bell, 2005).

\section{Samples and analytical methods}

New whole-rock analyses of five granites were made at Activation Laboratories, Ltd., Ancaster, Ontario, Canada (Table 2). All samples were crushed and powdered with mild steel before analysis. Inductively coupled plasma mass spectrometry (ICP-MS) and inductively coupled plasma optical 
Table 1. Location and lithology of the Paleogene granites used in this study and occurrences of $\mathrm{Zr}$ minerals.

\begin{tabular}{|c|c|c|c|c|c|c|c|c|c|c|c|}
\hline \multirow[b]{2}{*}{ Intrusion } & \multirow[b]{2}{*}{ Sample number } & \multirow[b]{2}{*}{ Lithology and granite type } & \multirow[b]{2}{*}{ M } & \multirow[b]{2}{*}{ LSM } & \multicolumn{2}{|c|}{ Zircon } & \multirow[b]{2}{*}{ Bdy } & \multirow[b]{2}{*}{$\mathrm{Zrc}$} & \multirow[b]{2}{*}{ EGM } & \multirow[b]{2}{*}{ Dly } & \multirow[b]{2}{*}{$\mathrm{FZr}$} \\
\hline & & & & & HT1 & HT2 & & & & & \\
\hline \multicolumn{12}{|l|}{ Skye } \\
\hline \multicolumn{12}{|l|}{ Skye: Eastern Red Hills Centre } \\
\hline Creag Strollamus Granite & H1226 & Porph. bi \pm amp granite (1) & $\checkmark$ & & $\checkmark$ & $\checkmark$ & & & & & \\
\hline Beinn na Cro Granite & H1200 & $\mathrm{Bi} \pm$ amp granite $(1)$ & $\checkmark$ & $\checkmark$ & & & & & & & \\
\hline Glas Bheinn Mhor Granite & GBME & Porph. bi \pm amp granophyre (1) & $\checkmark$ & & & & & & & & \\
\hline \multicolumn{12}{|l|}{ Skye: Western Red Hills Centre } \\
\hline (Northern) Porphyritic Felsite & NPF(sheared)\#1 & Porph. microgranite (2) & $\checkmark$ & & & $\checkmark$ & & & & & \\
\hline Loch Ainort Granite & H1554 & Porph. fa-fh granophyre (2) & $\checkmark$ & $\checkmark$ & $\checkmark$ & $\checkmark$ & & & & & \\
\hline Maol na Gainmich Granite & 14709 & Riebeckite granite (3) & $\checkmark$ & & & $\checkmark$ & & & & & \\
\hline Glamaig Granite & GLE2 & Porph. bi \pm amp granite (1) & $\checkmark$ & $\checkmark$ & & $\checkmark$ & & $\checkmark$ & & & \\
\hline \multicolumn{12}{|c|}{ Skye: Strath na Creitheach Centre } \\
\hline Meall Dearg Granite & MD & Porph. fa-fh microgranite (2) & $\checkmark$ & $\checkmark$ & & & & & & & \\
\hline Ruadh Stac Granite & RS1 & Riebeckite granophyre (3) & & & $\checkmark$ & & & & & & \\
\hline \multicolumn{12}{|l|}{ Rum } \\
\hline Western Granite & RUM & $\mathrm{Bi} \pm$ amp granophyre (1) & $\checkmark$ & & $\checkmark$ & & $\checkmark$ & & & & \\
\hline \multicolumn{12}{|l|}{ Ardnamurchan } \\
\hline Granophyre, Centre 2 & 14724 & Fa-fh granite (2) & $\checkmark$ & & & & $\checkmark$ & $\checkmark$ & & & \\
\hline Grigadale Granophyre & 13138 & Pyroxene granophyre (2) & $\checkmark$ & & $\checkmark$ & $\checkmark$ & $\checkmark$ & $\checkmark$ & & & \\
\hline \multicolumn{12}{|l|}{ Mull } \\
\hline Beinn a'Ghraig Granophyre & 13274 & Fa-fh granite (2) & $\checkmark$ & & & & & & & & \\
\hline Toll Doire Granophyre & 44858 & Fa-fh granophyre (2) & $\checkmark$ & $\checkmark$ & & & & & & & \\
\hline \multicolumn{12}{|l|}{ Ailsa Craig } \\
\hline Ailsa Craig granite & DV24828 & Riebeckite microgranite (3) & & & $\checkmark$ & $\checkmark$ & & & $\checkmark$ & $\checkmark$ & $\checkmark$ \\
\hline \multicolumn{12}{|l|}{ Mourne Mountains } \\
\hline G1 cumulate & G1 cum & Rich in mafics and accessories & $\checkmark$ & & & & & & & & \\
\hline
\end{tabular}

emission spectrometry (ICP-OES) were done using a lithium metaborate-tetraborate fusion procedure before sample dissolution or a multi-acid dissolution. Analytical methods employed were ICP-OES for the major elements and $\mathrm{Be}, \mathrm{Cu}, \mathrm{Ni}$, $\mathrm{Zn}, \mathrm{Ba}, \mathrm{Sr}, \mathrm{V}$, and $\mathrm{Zr}$, instrumental neutron activation analysis for $\mathrm{Cr}$, Sc, and As, and ICP-MS for all other trace elements. Loss of ignition (LOI) was determined at $1000^{\circ} \mathrm{C}$. Estimated relative uncertainties $(1 \sigma)$ were $\leq \pm 5 \%$ at 10 times the detection limit and $\pm 20 \%$ at the detection limit. Although, many of the analytical techniques used for the Ailsa Craig element analyses (Table 2) are outdated, we include this analysis for discussion of the Zr-bearing phases in the Ailsa Craig granite and also note that no detailed petrographic description is given for the sample (Govindaraju, 1987).

Thin sections were examined by a Hitachi SU5000 Schottky field emission scanning electron microscope (FE-SEM) using back-scattered electron (BSE) and secondary electron (SE) imaging to define points for analysis and for photomicrographs. The FE-SEM was equipped with an EDAX Octane $30 \mathrm{~mm}^{2}$ silicon drift detector (SDD). Operating conditions for mineral identification and data collection by energydispersive X-ray spectroscopy (EDS) using the SDD were 15 or $20 \mathrm{keV}, 50$ spot position ( $\sim 4 \mathrm{nA}$ probe current), and $200 \mathrm{~s}$ live counting time. EDS qualitative and semi-quantitative spectra were acquired and used to plan electron microprobe microanalysis (EPMA) procedures. Concentrations were calculated from the EDS count data using the EDAX factory standardization and either the eZAF or PeBaZAF quantification scheme. Cathodoluminescence (CL) imaging was obtained using a Hitachi ultra variable-pressure detector (UVD) operated at zero bias at high vacuum on the Hitachi FE-SEM. CL collection conditions were 10 or $15 \mathrm{keV}, 50$ spot position ( $\sim 4 \mathrm{nA}$ probe current), and $18 \mathrm{~mm}$ working distance. Quantitative electron microprobe analyses of major and minor elements were obtained with a JEOL JXA-8900 five spectrometer, a fully automated electron microprobe using wavelengthdispersive X-ray spectroscopy (WDS) at Reston, VA. Electron probe microanalysis experiments were made at $15 \mathrm{keV}$ accelerating voltage, $30 \mathrm{nA}$ probe current (Faraday cup), and counting times of $20-120 \mathrm{~s}$, using a $1 \mu \mathrm{m}$ or defocused probe spot. X-ray lines used for analyses were as follows: $K \alpha=$ $\mathrm{Si}$, Ti, Al, Fe, Mg, Ca, Mn, K, Na, Cl, F, P; $L \alpha=\mathrm{Ba}, \mathrm{Ce}, \mathrm{Sr}$, $\mathrm{Er}, \mathrm{La}, \mathrm{Y}, \mathrm{Yb}, \mathrm{Nb}$, Hf, Ta, Zr; $L \beta=\mathrm{Pr}, \mathrm{Nd}, \mathrm{Sm}, \mathrm{Gd}$, Dy, Eu; $M \alpha=\mathrm{Th}$; and $M \beta=\mathrm{U}, \mathrm{Pb}$. Detection limits $(3 \sigma)$ (as wt \%) were as follows: $\mathrm{K}, \mathrm{Na}=0.01 ; \mathrm{Si}, \mathrm{Al}, \mathrm{Fe}, \mathrm{Mg}, \mathrm{Ca}, \mathrm{Mn}=$ 0.02; Ti $=0.03 ; \mathrm{Sr}, \mathrm{P}, \mathrm{Cl}=0.04 ; \mathrm{Ba}=0.05 ; \mathrm{Pb}, \mathrm{Zr}, \mathrm{Th}, \mathrm{U}$, $\mathrm{Ta}=0.06$; Hf, Nb, Y, F = 0.08; La, Ce, Pr, Nd, Er, Yb = $0.10 ; \mathrm{Sm}, \mathrm{Gd}=0.12 ; \mathrm{Eu}=0.14 ;$ and $\mathrm{Dy}=0.15$. Standards 
Table 2. Chemical compositions of selected granites with Ailsa Craig.

\begin{tabular}{|c|c|c|c|c|c|c|}
\hline Granite & G. Bheinn Mh & Meall Dearg & Rudha Stac & N. Porphyr. & Glamaig & Ailsa Craig* \\
\hline Sample no. & GBME & MD & RS1 & NPF (sheared) & GLE2 & \\
\hline $\mathrm{SiO}_{2}(\mathrm{wt} \%)$ & 72.35 & 69.28 & 69.70 & 74.17 & 68.57 & 70.35 \\
\hline $\mathrm{TiO}_{2}$ & 0.41 & 0.47 & 0.34 & 0.28 & 0.64 & 0.11 \\
\hline $\mathrm{Al}_{2} \mathrm{O}_{3}$ & 12.58 & 12.57 & 12.43 & 11.65 & 13.60 & 14.70 \\
\hline $\mathrm{Fe}_{2} \mathrm{O}_{3} *$ & 4.24 & 5.99 & 4.61 & 3.71 & 5.41 & 2.53 \\
\hline $\mathrm{MnO}$ & 0.08 & 0.15 & 0.14 & 0.04 & 0.12 & 0.06 \\
\hline $\mathrm{MgO}$ & 0.24 & 0.11 & 0.05 & 0.13 & 0.61 & 0.03 \\
\hline $\mathrm{CaO}$ & 1.05 & 1.58 & 0.38 & 0.69 & 2.41 & 0.34 \\
\hline $\mathrm{Na}_{2} \mathrm{O}$ & 4.14 & 4.84 & 4.81 & 3.40 & 3.37 & 6.54 \\
\hline $\mathrm{K}_{2} \mathrm{O}$ & 4.53 & 4.92 & 5.53 & 4.51 & 4.79 & 4.49 \\
\hline $\mathrm{P}_{2} \mathrm{O}_{5}$ & 0.03 & 0.02 & $<0.01$ & $<0.01$ & 0.19 & 0.01 \\
\hline LOI & 0.58 & 0.63 & 0.62 & 0.08 & 0.73 & 0.37 \\
\hline Total & 100.23 & 100.56 & 98.61 & 98.66 & 100.44 & 99.53 \\
\hline Peralk Ix & 0.93 & 1.06 & 1.12 & 0.90 & 0.79 & 1.06 \\
\hline $\mathrm{Be}(\mathrm{ppm})$ & 3 & 3 & 4 & 1 & 2 & 12 \\
\hline $\mathrm{Ba}$ & 979 & 1583 & 892 & 385 & 1843 & 55 \\
\hline $\mathrm{Sr}$ & 71 & 107 & 30 & 40 & 132 & 3 \\
\hline $\mathrm{Rb}$ & 135 & 109 & 118 & 70 & 85 & 152 \\
\hline Cs & 0.9 & 1.4 & 2.5 & 0.1 & 0.7 & 3 \\
\hline V & 10 & $<5$ & $<5$ & 11 & 16 & 3 \\
\hline W & 1.4 & $<0.5$ & 31 & $<0.5$ & 3.2 & 1.5 \\
\hline $\mathrm{Co}$ & 3 & $<1$ & $<1$ & 2 & 4 & 0.2 \\
\hline $\mathrm{Cr}$ & $<5$ & $<5$ & $<5$ & $<5$ & 7 & 3.4 \\
\hline $\mathrm{Cu}$ & 8 & 5 & 3 & 132 & 12 & 4 \\
\hline $\mathrm{Ni}$ & 2 & 2 & $<1$ & 1 & 2 & 1.5 \\
\hline $\mathrm{Zn}$ & 106 & 197 & 208 & 34 & 104 & 224 \\
\hline $\mathrm{Pb}$ & 15 & 14 & 20 & 6 & 8 & 39 \\
\hline $\mathrm{Sn}$ & 4 & 3 & 4 & 2 & 2 & 13 \\
\hline As & 1.2 & $<0.5$ & 1.1 & 0.9 & $<0.5$ & 2.3 \\
\hline $\mathrm{Tl}$ & 0.66 & 0.59 & 0.50 & 0.36 & 0.42 & 0.9 \\
\hline $\mathrm{Zr}$ & 514 & 567 & 671 & 394 & 326 & 780 \\
\hline Hf & 11.3 & 12.4 & 14.1 & 9.6 & 6.7 & 27.9 \\
\hline $\mathrm{Nb}$ & 12.6 & 22.1 & 22.8 & 18.5 & 7.9 & 110 \\
\hline $\mathrm{Ta}$ & 1.30 & 1.32 & 1.30 & 1.06 & 0.72 & 6.4 \\
\hline $\mathrm{Ga}$ & 24 & 24 & 25 & 22 & 20 & 39 \\
\hline $\mathrm{Ge}$ & 1.5 & 1.6 & 1.3 & 1.2 & 1.1 & na \\
\hline $\mathrm{Th}$ & 8.79 & 6.27 & 6.86 & 5.76 & 5.16 & 18.5 \\
\hline $\mathrm{U}$ & 1.91 & 1.11 & 1.28 & 1.05 & 1.17 & 4.6 \\
\hline $\mathrm{Sc}$ & 4.7 & 4.9 & 1.8 & 1.5 & 9.5 & 0.11 \\
\hline $\mathrm{Y}$ & 85.8 & 120 & 108 & 70.4 & 45.4 & 184 \\
\hline $\mathrm{La}$ & 59.7 & 77.1 & 98.8 & 80.4 & 49.1 & 59 \\
\hline $\mathrm{Ce}$ & 121 & 160 & 202 & 192 & 98.5 & 154 \\
\hline $\operatorname{Pr}$ & 14.7 & 19.8 & 24.3 & 20.3 & 11.6 & 22.2 \\
\hline $\mathrm{Nd}$ & 59 & 74.3 & 88.8 & 73.5 & 45.1 & 92 \\
\hline $\mathrm{Sm}$ & 13.3 & 16.3 & 17.5 & 13.7 & 9.18 & 24.2 \\
\hline $\mathrm{Eu}$ & 2.38 & 3.5 & 2.29 & 1.82 & 2.76 & 2 \\
\hline $\mathrm{Gd}$ & 13.3 & 16.2 & 15.8 & 11.6 & 8.5 & 26 \\
\hline $\mathrm{Tb}$ & 2.35 & 3.11 & 2.96 & 2.04 & 1.29 & 4.8 \\
\hline Dy & 14.7 & 19.7 & 18.7 & 12.8 & 8.02 & 29 \\
\hline Ho & 3.04 & 4.25 & 3.92 & 2.63 & 1.65 & 6.5 \\
\hline $\mathrm{Er}$ & 9.12 & 12.7 & 11.6 & 7.87 & 4.85 & 17.7 \\
\hline $\mathrm{Tm}$ & 1.36 & 1.86 & 1.73 & 1.18 & 0.691 & 2.6 \\
\hline $\mathrm{Yb}$ & 9.02 & 12.2 & 11.4 & 8.08 & 4.53 & 17.4 \\
\hline $\mathrm{Lu}$ & 1.43 & 1.91 & 1.77 & 1.30 & 0.713 & 2.45 \\
\hline
\end{tabular}


were appropriate synthetic or natural materials available in the Reston Microbeam Laboratory (Huebner and Woodruff, 1985); Zr, Hf, and Th standards were provided through the courtesy of John M. Hanchar (Memorial University of Newfoundland). The analyses were corrected for electron beammatrix effects and instrumental drift and dead time using a Phi-Rho-Z scheme (CITZAF; Armstrong, 1995) as supplied with the JEOL JXA-8900R electron microprobe. The relative accuracy of the analyses, based upon comparison between measured and published compositions of standard reference materials available in the Reston Microbeam Laboratory, is $\sim 2 \%$ for element concentration $>1$ wt $\%$ and $\sim 5 \%-10 \%$ for element concentrations $<1 \mathrm{wt} \%$. The complete data sets for zircon and other Zr-bearing phases are given in the Supplement.

\section{Results - modes of occurrence and compositions of zircon}

Zircon is a ubiquitous accessory mineral in granitoids except in strongly peralkaline and agpaitic compositions in which other $\mathrm{Zr}$ species may predominate. Its stability and lack of common lead has made it a valuable tool in geochronology, especially with the advent of high-spatial- and high-massresolution ion probes (e.g., SHRIMP) and laser ablation ICPMS techniques (e.g., Harley and Kelly, 2007). Zr, Hf, and O isotope studies are used also to trace magma genesis, metamorphic reactions, and alteration mechanisms (e.g., Liu et al., 2009; Valley et al., 2010; Ibañez-Mejia and Tissot, 2019).

Zircon $\left(\mathrm{ZrSiO}_{4}\right)$, an orthosilicate, conforms to the formula $\mathrm{ABO}_{4}$, in which $\mathrm{A}$ represents the relatively large $\mathrm{Zr}$ ion in eight-fold coordination with $\mathrm{O}$, and $\mathrm{B}$ represents the $\mathrm{Si}$ ion in tetrahedral coordination with $\mathrm{O}$. Analyses of zircons in this report have been recalculated on the basis of the unit cell content of 16 oxygens (Deer et al., 1982; Finch and Hanchar, 2003). Zircon can have limited element substitution except for $\mathrm{Hf}$ in which complete solid solution exists between zircon and hafnon $\left(\mathrm{HfSiO}_{4}\right)$ (Ramakrishnan et al., 1969; Speer and Cooper, 1982). Hoskin and Schaltegger (2003) proposed the following trace-element distributions in the structure of zircon: four-fold site $-\mathrm{Si}^{4+}, \mathrm{P}^{5+}$; eight-fold site $-\mathrm{Zr}^{4+}, \mathrm{Hf}^{4+}$, $\mathrm{Y}^{3+}, \mathrm{REE}^{3+}$ (rare earth element), $\mathrm{U}^{4+}, \mathrm{Th}^{4+}, \mathrm{Pb}^{4+}$ (only radiogenic), $\mathrm{Ti}^{4+}, \mathrm{Sn}^{4+}, \mathrm{Sc}^{3+}, \mathrm{Al}^{3+}, \mathrm{Nb}^{5+}, \mathrm{Ta}^{5+}$; and interstitial site $-\mathrm{Li}^{+}, \mathrm{Mg}^{2+}, \mathrm{Fe}^{2+}, \mathrm{Mn}^{2+}, \mathrm{Al}^{3+}, \mathrm{Fe}^{3+}$. Element substitution can be a simple isovalent replacement of $\mathrm{Zr}$ by other tetravalent cations or coupled if divalent and trivalent cations are incorporated (Hoskin and Schaltegger, 2003).

Hoskin and Schaltegger (2003) summarized the following simple and coupled element substitutions commonly observed in zircon: (1) simple substitutions: $\mathrm{Hf}^{4+}=\mathrm{Zr}^{4+}$, $\left(\mathrm{U}^{4+}, \mathrm{Th}^{4+}, \mathrm{Ti}^{4+}, \mathrm{Sn}^{4+}\right)=\mathrm{Zr}^{4+},(\mathrm{OH})_{4}^{4-}=\mathrm{SiO}_{4}^{4-} ;(2)$ coupled substitutions: $a-$ at one structural site: $(\mathrm{Y}, \mathrm{REE})^{3+}+$ $(\mathrm{Nb}, \mathrm{Ta})^{5+}=2 \mathrm{Zr}^{4+} ; b-$ at two structural sites: $(\mathrm{Y}, \mathrm{REE})^{3+}+$ $\mathrm{P}^{5+}=\mathrm{Zr}^{4+}+\mathrm{Si}^{4+},(\mathrm{Sc})^{3+}+\mathrm{P}^{5+}=\mathrm{Zr}^{4+}+\mathrm{Si}^{4+}, M^{n+}+$
$n(\mathrm{OH})^{-}+(4-n) \mathrm{H}_{2} \mathrm{O}=\mathrm{Zr}^{4+}+(\mathrm{SiO} 4)^{4-}$ (where $M=$ metal cation and $n=$ integer); and $c-$ at an interstitial site: $(\mathrm{Mg}, \mathrm{Fe})^{2+}(\mathrm{int})+3(\mathrm{Y}, \mathrm{REE})^{3+}+\mathrm{P}^{5+}=3 \mathrm{Zr}^{4+}+\mathrm{Si}^{4+}$, $(\mathrm{Al}, \mathrm{Fe})^{3+}$ (int) $+4(\mathrm{Y}, \mathrm{REE})^{3+}+\mathrm{P}^{5+}=4 \mathrm{Zr}^{4+}+\mathrm{Si}^{4+}$. The most common substitutions in zircon are $\mathrm{Hf}^{4+}=\mathrm{Zr}^{4+}$ and the "xenotime" substitution $(\mathrm{Y}, \mathrm{REE})^{3+}+\mathrm{P}^{5+}=\mathrm{Zr}^{4+}+\mathrm{Si}^{4+}$ (Speer, 1982).

Although, xenotime substitution appears to be the dominant trace-element substitution mechanism in many zircons, Hoskin and Schaltegger (2003) point out that the common occurrence of REEs $(\mathrm{mol} \%)$ in excess of $\mathrm{P}(\mathrm{mol} \%)$ in natural zircon indicates that other mechanisms also operate. In the studied zircons, many have REEs (mol \%) in excess of $\mathrm{P}$ (mol \%); thus, other substitution mechanisms in addition to the xenotime type were operative. We have used the sum of $\Sigma \mathrm{REE}+\mathrm{Y}+\mathrm{P}$ apfu (atom per formula unit; not including $\mathrm{U}$ or Th) as a measure of the degree of trace-element substitution and deviation from ideal zircon.

In the studied samples, zircon is the main $\mathrm{Zr}$ mineral except in the Ailsa Craig peralkaline granite in which dalyite and a eudialyte-group mineral predominate. On the basis of texture primarily and composition, the zircon population is classified into four groups: magmatic, late-stage magmatic, hydrothermal type 1, and hydrothermal type 2 .

\subsection{Magmatic zircons}

Magmatic zircons are defined as those that crystallized from a silicate melt during early zircon saturation. Magmatic zircons have been identified in all samples except the Ruadh Stac Granite and Ailsa Craig microgranite (Table 1). Harding (1983) reports no zircons found in his eight Ailsa Craig samples, whereas Harrison et al. (1987) report zircons in the crush but do not give a detailed petrographic description. All the magmatic zircons are subhedral to euhedral prisms (Fig. 2a, b, d, g), with common combinations of prism $(\{100\}$ and $\{110\})$ and pyramid forms $(\{211\},\{101\}$ and $\{301\})$. Their length-to-width ratio is usually $2: 1$ to $4: 1$, although a few were more acicular and have ratios of $6: 1$ to $8: 1$ (Fig. 2h). They range in size from $10-500 \mu \mathrm{m}$. All have some degree of oscillatory and/or sector zoning (Fig. 2c, e, f, g, i), typical of igneous magmatic zircon (Hoskin and Schaltegger, 2003). Silicate melt (Fig. 2a, b, g) and apatite (Fig. 2d, h) are the most common inclusions, although britholite (Fig. 2b), quartz, pyrrhotite, chevkinite-(Ce), titanomagnetite, and $\mathrm{K}$ feldspar inclusions are also present. We did not have sufficient sample to attempt any microthermometric studies of the silicate-melt inclusions but tentatively identified them by their round or ovoid shape (Fig. 2b, g); a few had a negative crystal shape (Fig. 2a). All had low BSE response, as would be expected for trapped high $\mathrm{SiO}_{2}$ compositions. The magmatic zircon compositions do not differ appreciably from ideal $\mathrm{ZrSiO}_{4}$ (Tables 3, 4). $\mathrm{HfO}_{2}$ ranges from $0.70 \mathrm{wt} \%$ 1.37 wt $\%$ and $\mathrm{Zr} / \mathrm{Hf} w / w$ from $42-81$, although $95 \%$ fall between 42-65 (Fig. 3a). Trace-element substitution is mi- 
nor, and $\Sigma \mathrm{REE}+\mathrm{Y}+\mathrm{P}$ varies from $0.018-0.146$ apfu $(16$ oxygen basis) (Fig. 4a). The contents of $\Sigma \mathrm{REE}, \mathrm{Y}_{2} \mathrm{O}_{3}, \mathrm{ThO}_{2}$, and $\mathrm{UO}_{2}$ are generally low (Figs. 5a and 6a). There is no significant compositional difference among all the magmatic zircons. Additionally, we observed no textures characteristic of inherited zircons in any of the samples (e.g., Paterson et al., 1992; Aleinikoff et al., 2006). This lack of an inherited zircon component points to an origin of the granites being dominantly by fractional crystallization of mafic magmas with insignificant crustal contamination, as suggested by Gamble et al. (1992, 1999) for Paleogene granites of Slieve Gullion and Mourne Mountains.

\subsection{Late-stage magmatic zircons}

In a few cases, anhedral magmatic zircons are seen to have grown in the interstices and spaces between crystals formed earlier. These relatively late-crystallizing zircons have oscillatory and/or sector zoning, contain silicate-melt inclusions (Fig. 7a, b, c), and are compositionally indistinguishable from earlier magmatic zircons in the same sample. $\mathrm{HfO}_{2}$ varies from $0.99 \mathrm{wt} \%-1.33 \mathrm{wt} \%$, and $\mathrm{Zr} / \mathrm{Hf} w / w$ ranges from 43-58 (Fig. 3b; Table 5). Trace-element substitution is minor (0.031-0.059 apfu; Fig. 4b), and the abundances of $\Sigma$ REE, $\mathrm{Y}_{2} \mathrm{O}_{3}, \mathrm{ThO}_{2}$, and $\mathrm{UO}_{2}$ are low (Figs. $5 \mathrm{~b}$ and $6 \mathrm{~b}$; Table 5).

\subsection{Hydrothermal zircons type 1 and type 2}

For this study, hydrothermal zircons are defined as those precipitated from an aqueous-dominated, solute-rich fluid of magmatic origin. Such fluids typically exsolve from granitoid bodies during the later stages of cooling. Two hydrothermal zircon types are distinguished primarily on texture. We did not observe any textures that suggested that the hydrothermal zircons resulted from the alteration of magmatic zircon. Hydrothermal type 1 zircons are either anhedral, filling interstices and spaces between earlier formed crystals, or are uncommon euhedral crystals in vugs, essentially devoid of inclusions and enriched in incompatible elements such as Y, Th, U, and $\Sigma$ REE. Hydrothermal type 2 zircons are filled with fluid and solid inclusions and are, in many cases, less enriched in incompatible elements than type 1, except those from Ailsa Craig. Both types, except for Ailsa Craig type 2, have EPMA sums that suggest no $\mathrm{OH}^{-}$or $\mathrm{H}_{2} \mathrm{O}$ component.

\subsubsection{Hydrothermal type 1 zircons}

Hydrothermal type 1 zircons were identified in six samples (Table 1). The category includes zircon that has replaced baddeleyite (see below). The zircons are anhedral, filling interstices and cracks (Fig. 8a, c), and do not display oscillatory or sector zoning but appear patchy or diffusely zoned in CL or BSE images (Fig. 8b, c). In a few cases euhedral crystals occur in vugs (Fig. 8d). Type 1 has a large range of $\mathrm{HfO}_{2}$ (0.58 wt \%-2.79 wt \%), and $\mathrm{Zr} / \mathrm{Hf} w / w$ varies from $18-91$, but most are between 37-70 (Fig. 3c; Tables 6, 7). Traceelement substitution is significantly greater than the magmatic type, and $\Sigma \mathrm{REE}+\mathrm{Y}+\mathrm{P}$ varies from $0.149-0.695$ apfu (Fig. 4c; Tables 6 and 7). The simple substitution, $\mathrm{U}^{4+}+$ $\mathrm{Th}^{4+}=\mathrm{Zr}^{4+}$, is also present. There is a positive correlation between $\mathrm{Y}_{2} \mathrm{O}_{3}$ and $\Sigma$ REE (Fig. 5c) and $\mathrm{ThO}_{2}$ and $\mathrm{UO}_{2}$ (Fig. 6c), with $\mathrm{ThO}_{2}$ usually greater than $\mathrm{UO}_{2}$. In one case, the textures suggest that the fluids forming a hydrothermal type 1 zircon have partially altered an earlier chevkinite-(Ce) crystal (Fig. 8a) but do not appear to have altered the other adjacent phases.

\subsubsection{Hydrothermal type 2 zircons}

Hydrothermal type 2 zircons are fluid- and solid-inclusionrich. Those in Ailsa Craig are placed in type 2 because they have cavities but no fluid inclusions sensu stricto (Roedder, 1984). Type 2 are most abundant in the Skye Western Centre and Eastern Red Hills Centre and less common in the Ardnamurchan Grigadale Granophyre (Table 1). Figure 9a illustrates the transition, sometimes observed, between type 1 and type 2. A type 1 zircon has begun to fill a space between magnetite grains, when the zircon began to trap both fluid and solid inclusions (Fig. 9a). In other cases, type 2 zircon precipitated around an earlier-formed magmatic zircon, yet it displays a euhedral form (Fig. 9b, c). Groups of inclusion-rich zircons also occur at grain boundaries (Fig. 9e) and fill interstices among crystals (Fig. 9f). We identified (EDS) xenotime, thorite, fergusonite, calcite, REE $+\mathrm{Y}$ fluorcarbonate, U,Y,Si carbonate, britholite, Fe oxide, quartz, chlorite, probable hingganite-(Y), and probable hellandite-(Y) as solid inclusions (e.g., Fig. 9d1, d2 ,d3). There are no inclusion assemblages to suggest that the included phases were daughter minerals (Roedder, 1984), and so they are interpreted to be accidentally trapped solids. Figure 9a shows the transition between hydrothermal type 1 with a high incompatible element content (pt. $1-\mathrm{Y}_{2} \mathrm{O}_{3} 5.04, \mathrm{ThO}_{2} 1.03 \mathrm{wt} \%$; Table 6, analysis H1226_Z1core) and hydrothermal type 2 zircon with a low incompatible element content (pt. $2-\mathrm{Y}_{2} \mathrm{O}_{3}$ $0.37, \mathrm{ThO}_{2} 0.19 \mathrm{wt} \%$; Table 8, analysis H1226_Z1rim). The presence of $Y$ - and Th-bearing trapped minerals in type 2 indicates that the zircon-forming fluid was precipitating Y-and Th-rich phases, hence depleting the fluid and zircon in those elements.

The Ailsa Craig hydrothermal type 2 zircons have a distinct habit and composition different from the other type 2 zircons. The Ailsa Craig zircon fills vugs and has cavities lined with a botryoidal texture (Fig. $9 \mathrm{~g}$ ). $\mathrm{HfO}_{2}$ varies between $0.91 \mathrm{wt} \%-1.26 \mathrm{wt} \%$ and $\mathrm{Zr} / \mathrm{Hf} w / w$ is in a narrow range between 32-43 (Fig. 3d; Table 9). Trace-element substitution $(\Sigma R E E+\mathrm{Y}+\mathrm{P})$ varies from $0.38-0.91$ apfu and has a scattered distribution (Fig. 4d). The zircons have high $\mathrm{Y}_{2} \mathrm{O}_{3}$ and $\Sigma$ REE contents (Fig. 5d), but in contrast to all other studied zircons, they have relatively high LREE (La-Gd REE) contents and compared to other hydrothermal type 1 and 2 


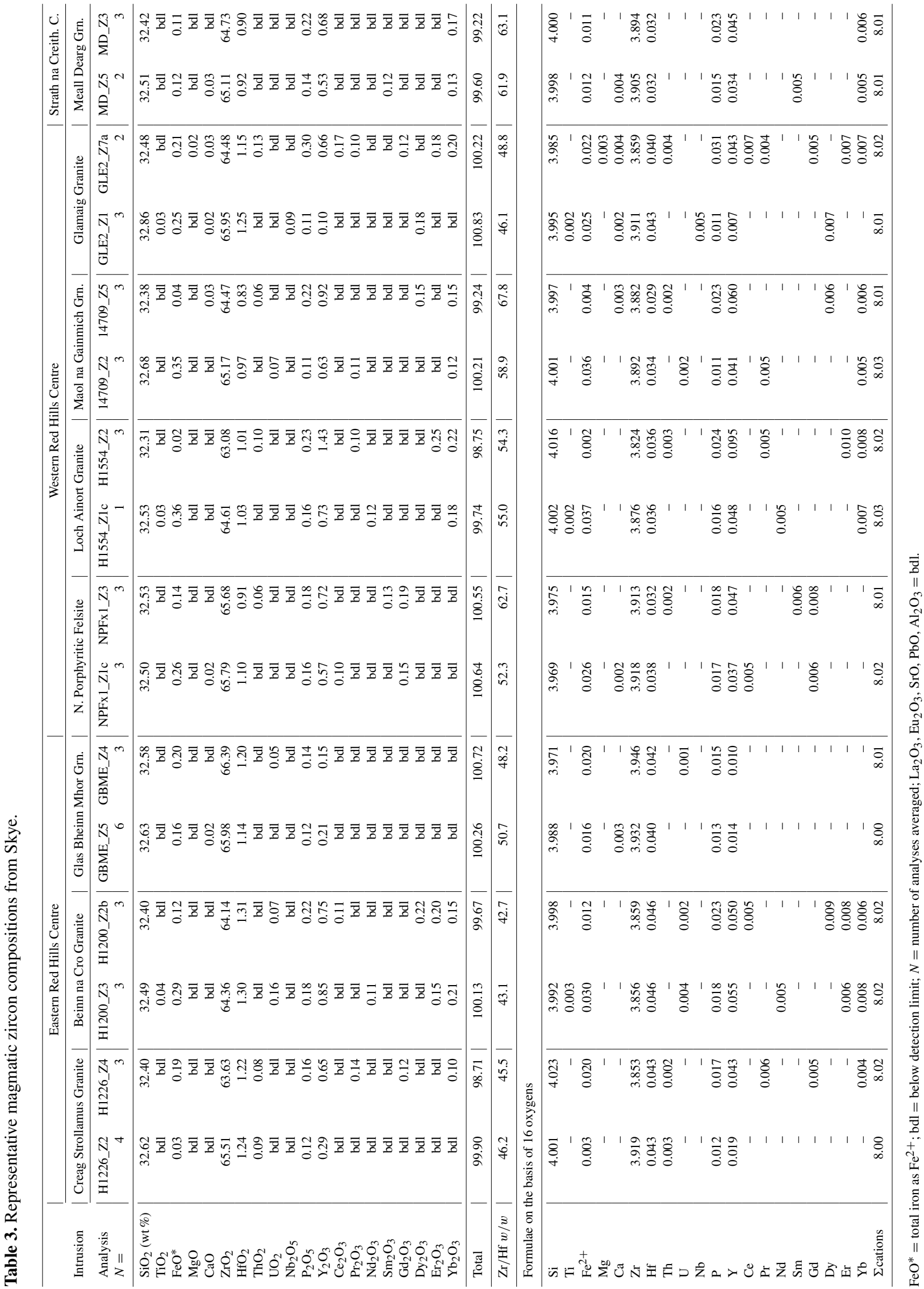




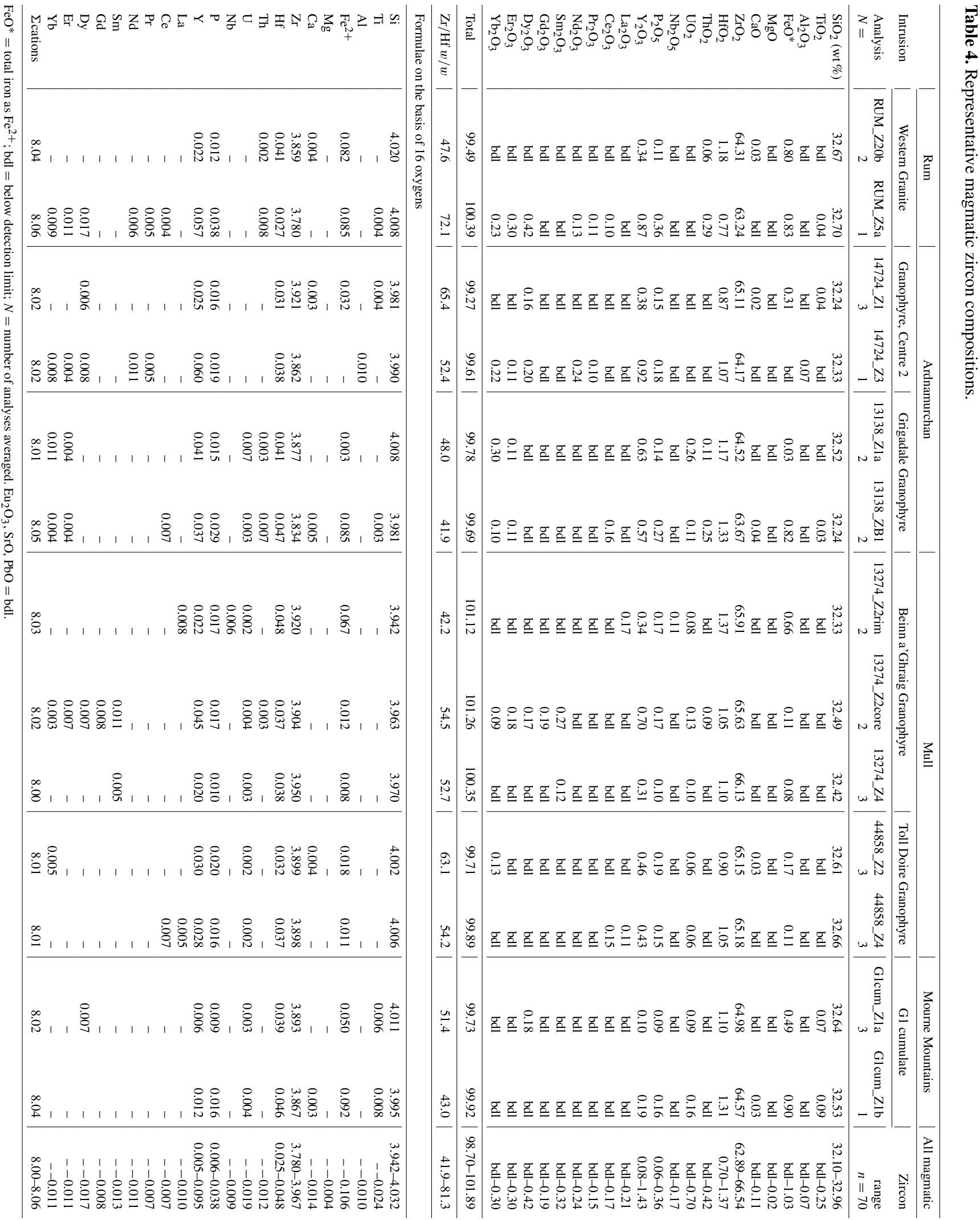


Table 5. Late-stage magmatic zircon compositions.

\begin{tabular}{|c|c|c|c|c|c|c|}
\hline \multirow{5}{*}{$\begin{array}{l}\text { Intrusion } \\
\text { Analysis } \\
N=\end{array}$} & \multicolumn{5}{|c|}{ Skye } & \multirow[b]{2}{*}{ Mull } \\
\hline & East. Red Hills & \multicolumn{3}{|c|}{ Western Red Hills Centre } & \multirow{3}{*}{$\begin{array}{r}\text { Strath Creith. } \\
\text { Meall Dearg } \\
\text { MD_Z1 }\end{array}$} & \\
\hline & Beinn Cro & N. Porph. Fels. & Glamaig & Granite & & Toll Doire \\
\hline & H1200_Z1 & H1554_Z1a & GLE2_Z8 & GLE2_Z9 & & 44858_Z3 \\
\hline & 4 & 2 & 3 & 2 & 3 & 4 \\
\hline $\mathrm{SiO}_{2}(\mathrm{wt} \%)$ & 32.54 & 32.87 & 32.72 & 32.80 & 32.78 & 32.56 \\
\hline $\mathrm{TiO}_{2}$ & 0.13 & 0.03 & bdl & bdl & bdl & bdl \\
\hline $\mathrm{Al}_{2} \mathrm{O}_{3}$ & bdl & bdl & bdl & bdl & 0.03 & bdl \\
\hline $\mathrm{FeO}^{*}$ & 0.73 & 0.37 & 0.10 & 0.32 & 0.68 & 0.06 \\
\hline $\mathrm{CaO}$ & 0.02 & 0.02 & bdl & 0.02 & 0.06 & 0.02 \\
\hline $\mathrm{ZrO}_{2}$ & 65.18 & 66.02 & 65.18 & 64.60 & 65.23 & 65.04 \\
\hline $\mathrm{HfO}_{2}$ & 1.33 & 1.12 & 1.28 & 1.08 & 0.99 & 1.20 \\
\hline $\mathrm{ThO}_{2}$ & bdl & bdl & bdl & bdl & bdl & 0.08 \\
\hline $\mathrm{UO}_{2}$ & bdl & bdl & bdl & 0.12 & bdl & 0.08 \\
\hline $\mathrm{P}_{2} \mathrm{O}_{5}$ & 0.10 & 0.08 & 0.17 & 0.17 & 0.11 & 0.14 \\
\hline $\mathrm{Y}_{2} \mathrm{O}_{3}$ & 0.49 & 0.10 & 0.36 & 0.32 & 0.49 & 0.38 \\
\hline $\mathrm{La}_{2} \mathrm{O}_{3}$ & bdl & 0.16 & bdl & bdl & bdl & bdl \\
\hline $\mathrm{Ce}_{2} \mathrm{O}_{3}$ & bdl & 0.11 & bdl & bdl & bdl & bdl \\
\hline $\mathrm{Pr}_{2} \mathrm{O}_{3}$ & bdl & bdl & bdl & 0.14 & bdl & bdl \\
\hline $\mathrm{Sm}_{2} \mathrm{O}_{3}$ & 0.17 & bdl & bdl & bdl & 0.15 & bdl \\
\hline $\mathrm{Dy}_{2} \mathrm{O}_{3}$ & bdl & bdl & bdl & bdl & bdl & 0.15 \\
\hline $\mathrm{Er}_{2} \mathrm{O}_{3}$ & 0.14 & 0.10 & bdl & bdl & 0.14 & bdl \\
\hline $\mathrm{Yb}_{2} \mathrm{O}_{3}$ & 0.10 & bdl & 0.10 & 0.11 & bdl & bdl \\
\hline Total & 100.93 & 100.99 & 99.90 & 99.69 & 100.66 & 99.70 \\
\hline $\mathrm{Zr} / \mathrm{Hf} w / w$ & 42.7 & 51.3 & 44.5 & 52.0 & 57.7 & 47.5 \\
\hline \multicolumn{7}{|c|}{ Formulae on the basis of 16 oxygens } \\
\hline $\mathrm{Si}$ & 3.972 & 3.995 & 4.010 & 4.025 & 3.996 & 4.005 \\
\hline $\mathrm{Ti}$ & 0.012 & 0.003 & - & - & - & - \\
\hline $\mathrm{Al}$ & 0.001 & - & - & - & 0.004 & - \\
\hline $\mathrm{Fe}^{2+}$ & 0.075 & 0.038 & 0.010 & 0.032 & 0.069 & 0.006 \\
\hline $\mathrm{Ca}$ & 0.002 & 0.003 & - & 0.003 & 0.008 & 0.003 \\
\hline $\mathrm{Zr}$ & 3.880 & 3.913 & 3.895 & 3.865 & 3.878 & 3.901 \\
\hline Hf & 0.046 & 0.039 & 0.045 & 0.038 & 0.034 & 0.042 \\
\hline Th & - & - & - & - & - & 0.002 \\
\hline $\mathrm{U}$ & - & - & - & 0.003 & - & 0.002 \\
\hline $\mathrm{P}$ & 0.010 & 0.008 & 0.018 & 0.018 & 0.011 & 0.014 \\
\hline $\mathrm{Y}$ & 0.032 & 0.006 & 0.023 & 0.021 & 0.032 & 0.025 \\
\hline $\mathrm{La}$ & - & 0.007 & - & - & - & - \\
\hline $\mathrm{Ce}$ & - & 0.005 & - & - & - & - \\
\hline $\operatorname{Pr}$ & - & - & - & 0.006 & - & - \\
\hline $\mathrm{Sm}$ & 0.007 & - & - & - & 0.006 & - \\
\hline Dy & - & - & - & - & - & 0.006 \\
\hline $\mathrm{Er}$ & 0.005 & 0.004 & - & - & 0.005 & - \\
\hline $\mathrm{Yb}$ & 0.004 & - & 0.004 & 0.004 & - & - \\
\hline$\sum$ cations & 8.05 & 8.02 & 8.00 & 8.02 & 8.04 & 8.01 \\
\hline
\end{tabular}

$\mathrm{FeO}^{*}=$ total iron as $\mathrm{Fe}^{2+} ;$ bdl $=$ below detection limit; $N=$ number of analyses averaged. $\mathrm{Nb}_{2} \mathrm{O}_{5}, \mathrm{Nd}_{2} \mathrm{O}_{3}, \mathrm{Eu}_{2} \mathrm{O}_{3}, \mathrm{Gd}_{2} \mathrm{O}_{3}, \mathrm{SrO}, \mathrm{PbO}, \mathrm{MgO}$ $=$ bdl. 

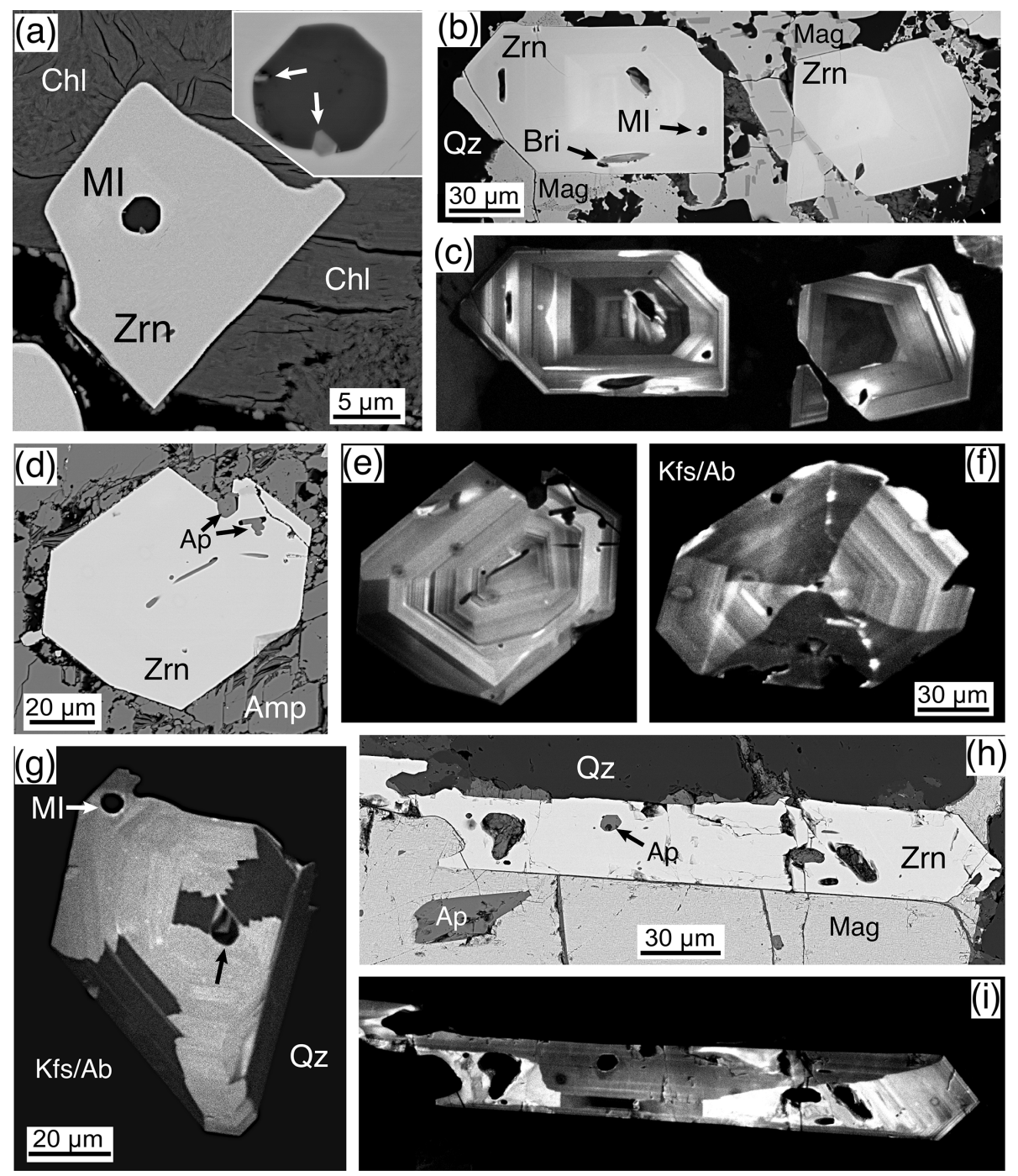

Figure 2. Magmatic zircons, BSE images except where noted. (a) A $20 \mu \mathrm{m}$ euhedral zircon (Zrn) enclosed by chlorite (Chl) with a $2.5 \mu \mathrm{m}$ silicate-melt inclusion (MI). The inclusion is enlarged in the upper right; the lower arrow indicates a euhedral-zoned apatite, and the upper arrow points to a $\mathrm{TiO}_{2}$ phase. Rum, Western Granite, sample RUM. (b) Two $~ 90 \mu$ m euhedral zircons (Zrn) with silicate-melt (MI), and britholite (Bri) inclusions, enclosed by quartz (Qz) with magnetite (Mag). Mull, Toll Doire Granophyre, sample 44858. (c) CL image of (b) showing sharply defined magmatic oscillatory zoning. (d) An $80 \mu \mathrm{m}$ euhedral zircon (Zrn) with apatite (Ap) inclusions enclosed by riebeckite amphibole (Amp) somewhat disaggregated from sample preparation. Skye, Western Red Hills Centre, Maol na Gainmich Granite, sample 14709. (e) CL image of (d) showing fine-scale oscillatory zoning; the left border shows sector zoning. (f) CL image of a $130 \mu \mathrm{m}$ euhedral zircon enclosed by K-feldspar and albite (Kfs/Ab) showing fine-scale oscillatory zoning with well-developed sector zoning. Skye, Eastern Red Hills Centre, Creag Strollamus Granite, sample H1226. (g) A CL image of an $80 \mu \mathrm{m}$ zircon (Zrn) surrounded by quartz (Qz) and Kfeldspar and albite (Kfs/Ab) with well-developed sector zoning. The crystal contains a silicate-melt inclusion (MI) in the upper left, but the similarly shaped dark spot (black arrow) is a non-CL part of the crystal. Skye, Eastern Red Hills Centre, Glas Bheinn Mhor Granite, sample GBME. (h) An acicular $300 \mu \mathrm{m}$ (a portion on the left not shown) euhedral zircon (Zrn) on magnetite and intergrown (left portion) with quartz (Qz). Apatite inclusions (Ap) in both the zircon and magnetite. Skye, Eastern Red Hills Centre, Glas Bheinn Mhor Granite, sample GBME. (i) A CL image of (h) showing oscillatory and sector zoning.

zircons have high $\mathrm{CaO}$ and $\mathrm{Al}_{2} \mathrm{O}_{3}$ values (Table 9). The contents of $\mathrm{ThO}_{2}$ and $\mathrm{UO}_{2}$ are all $<0.5 \mathrm{wt} \%$ except for one value (Fig. 6d). Figure $9 \mathrm{~g}$ shows that the zircon formed after the precipitation of a pyrochlore-group mineral and the Ailsa Craig hydrothermal type 2 zircons have high $\mathrm{Nb}_{2} \mathrm{O}_{5}$ contents in contrast to magmatic zircons (Table 9). The EPMA totals varied from $92 \mathrm{wt} \%-96 \mathrm{wt} \%$. These are hydrous zircons, but the hydrous value $\left(\mathrm{H}_{2} \mathrm{O}, \mathrm{OH}^{1-}\right)$ is not the difference from $100 \%$ as we did not measure all REEs or $\mathrm{B}, \mathrm{Be}$, or $\mathrm{Li}$, for example. 

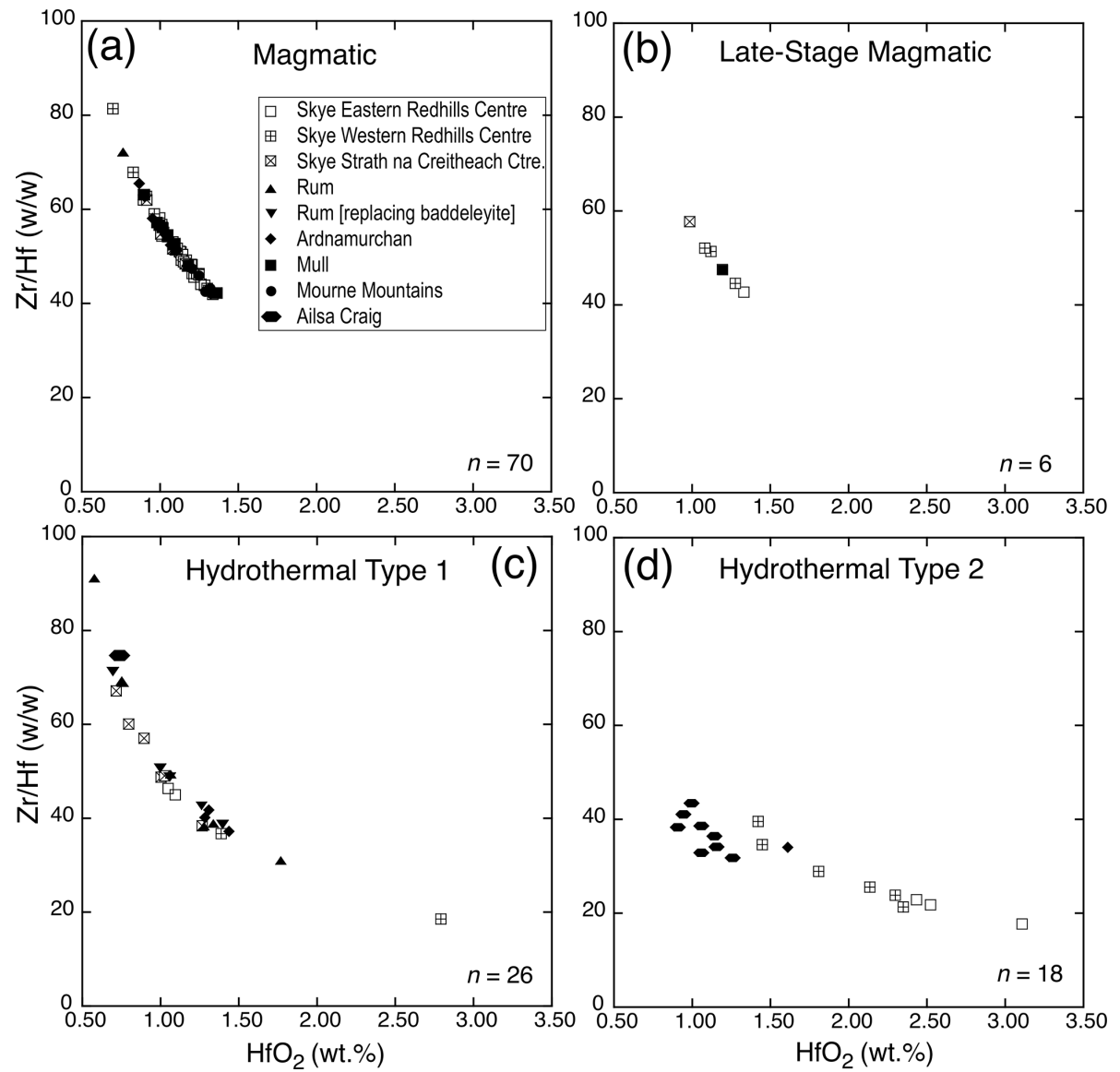

Figure 3. Variation in $\mathrm{Zr} / \mathrm{Hf} w / w$ versus $\mathrm{HfO}_{2}$ in the four types of studied zircons: (a) magmatic, (b) late-stage magmatic, (c) hydrothermal type 1, and (d) hydrothermal type 2. The legend shown in (a) applies to all four types where appropriate and is valid for Figs. 4, 5, and 6.
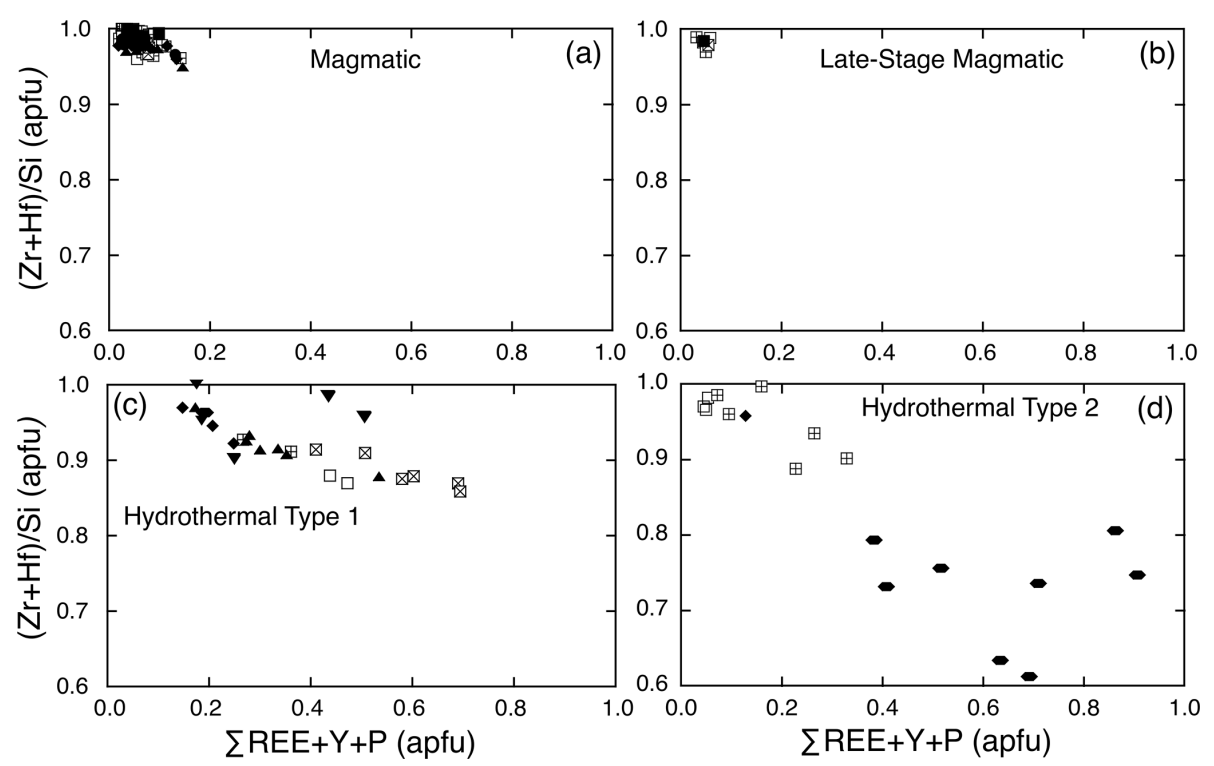

Figure 4. Deviation from ideal $\mathrm{ZrSiO}_{4}$ by trace-element $(\Sigma \mathrm{REE}+\mathrm{Y}+\mathrm{P})$ substitutions in the studied zircons: (a) magmatic, (b) late-stage magmatic, (c) hydrothermal type 1, and (d) hydrothermal type 2. 
Table 6. Representative hydrothermal type 1 zircon compositions from Skye

\begin{tabular}{|c|c|c|c|c|c|c|c|}
\hline \multirow{5}{*}{$\begin{array}{l}\text { Intrusion } \\
\text { Analysis } \\
N=\end{array}$} & \multicolumn{7}{|c|}{ Skye } \\
\hline & \multicolumn{2}{|c|}{ Eastern Red Hills Centre } & \multicolumn{2}{|c|}{ Western Red Hills C. } & \multicolumn{3}{|c|}{ Strath na Creith. Centre } \\
\hline & \multicolumn{2}{|c|}{ Creag Strollamus Granite } & \multicolumn{2}{|c|}{ Loch Ainort Granite } & \multicolumn{3}{|c|}{ Ruadh Stac Granite } \\
\hline & H1226_Z1core & H1226_Z5core & H1554_Z4 & H1554_Z5 & RS1_Z2 & RS1_Z4 & RS1_Z5 \\
\hline & 2 & 2 & 3 & 3 & 6 & 4 & 3 \\
\hline $\mathrm{SiO}_{2}(\mathrm{wt} \%)$ & 31.57 & 31.65 & 31.95 & 31.68 & 31.45 & 31.21 & 31.48 \\
\hline $\mathrm{TiO}_{2}$ & 0.07 & bdl & bdl & bdl & bdl & bdl & bdl \\
\hline $\mathrm{FeO}^{*}$ & 0.85 & 0.35 & 0.52 & 0.14 & 0.05 & 0.09 & 0.06 \\
\hline $\mathrm{CaO}$ & 0.11 & 0.16 & bdl & 0.02 & bdl & bdl & bdl \\
\hline $\mathrm{ZrO}_{2}$ & 55.65 & 56.42 & 59.08 & 58.36 & 55.67 & 55.19 & 54.92 \\
\hline $\mathrm{HfO}_{2}$ & 1.05 & 1.10 & 2.79 & 1.39 & 1.27 & 0.72 & 0.80 \\
\hline $\mathrm{ThO}_{2}$ & 1.03 & 1.20 & 0.94 & 0.64 & 0.19 & 0.25 & 0.33 \\
\hline $\mathrm{UO}_{2}$ & 0.53 & 0.53 & 0.23 & 0.28 & 0.06 & 0.12 & 0.13 \\
\hline $\mathrm{Nb}_{2} \mathrm{O}_{5}$ & bdl & bdl & 0.27 & 0.10 & bdl & bdl & bdl \\
\hline $\mathrm{P}_{2} \mathrm{O}_{5}$ & 0.25 & 0.18 & 0.32 & 0.27 & 0.73 & 0.81 & 0.62 \\
\hline $\mathrm{Y}_{2} \mathrm{O}_{3}$ & 5.04 & 4.53 & 2.80 & 3.78 & 6.02 & 6.93 & 7.40 \\
\hline $\mathrm{La}_{2} \mathrm{O}_{3}$ & bdl & 0.13 & bdl & bdl & bdl & bdl & bdl \\
\hline $\mathrm{Ce}_{2} \mathrm{O}_{3}$ & 0.14 & 0.10 & bdl & bdl & bdl & bdl & 0.13 \\
\hline $\mathrm{Pr}_{2} \mathrm{O}_{3}$ & bdl & bdl & bdl & bdl & bdl & 0.08 & bdl \\
\hline $\mathrm{Nd}_{2} \mathrm{O}_{3}$ & bdl & bdl & bdl & bdl & bdl & bdl & 0.14 \\
\hline $\mathrm{Sm}_{2} \mathrm{O}_{3}$ & bdl & 0.15 & bdl & bdl & bdl & bdl & bdl \\
\hline $\mathrm{Eu}_{2} \mathrm{O}_{3}$ & bdl & 0.15 & bdl & bdl & bdl & 0.22 & 0.20 \\
\hline $\mathrm{Gd}_{2} \mathrm{O}_{3}$ & 0.26 & 0.13 & 0.18 & 0.21 & 0.53 & 0.73 & 0.65 \\
\hline $\mathrm{Dy}_{2} \mathrm{O}_{3}$ & 0.33 & 0.19 & 0.22 & 0.38 & 0.81 & 0.99 & 1.17 \\
\hline $\mathrm{Er}_{2} \mathrm{O}_{3}$ & 0.71 & 0.66 & 0.29 & 0.42 & 0.62 & 0.83 & 0.51 \\
\hline $\mathrm{Yb}_{2} \mathrm{O}_{3}$ & 1.18 & 1.27 & 0.51 & 0.96 & 0.37 & 0.44 & 0.32 \\
\hline Total & 98.95 & 98.97 & 100.34 & 98.81 & 98.17 & 98.64 & 99.06 \\
\hline $\mathrm{Zr} / \mathrm{Hf} w / w$ & 46.3 & 44.9 & 18.5 & 36.7 & 38.3 & 67.1 & 60.0 \\
\hline \multicolumn{8}{|c|}{ Formulae on the basis of 16 oxygens } \\
\hline $\mathrm{Si}$ & 4.026 & 4.033 & 3.996 & 4.013 & 4.006 & 3.971 & 3.996 \\
\hline $\mathrm{Ti}$ & 0.007 & - & - & - & - & - & - \\
\hline $\mathrm{Fe}^{2+}$ & 0.091 & 0.037 & 0.055 & 0.015 & 0.006 & 0.009 & 0.007 \\
\hline $\mathrm{Ca}$ & 0.016 & 0.022 & - & 0.003 & - & - & - \\
\hline $\mathrm{Zr}$ & 3.461 & 3.507 & 3.603 & 3.605 & 3.459 & 3.424 & 3.401 \\
\hline $\mathrm{Hf}$ & 0.038 & 0.040 & 0.100 & 0.050 & 0.046 & 0.026 & 0.029 \\
\hline $\mathrm{Th}$ & 0.030 & 0.035 & 0.027 & 0.018 & 0.006 & 0.007 & 0.010 \\
\hline $\mathrm{U}$ & 0.015 & 0.015 & 0.006 & 0.008 & 0.002 & 0.003 & 0.004 \\
\hline $\mathrm{Nb}$ & - & - & 0.015 & 0.006 & - & - & - \\
\hline $\mathrm{P}$ & 0.027 & 0.019 & 0.034 & 0.029 & 0.078 & 0.087 & 0.067 \\
\hline $\mathrm{Y}$ & 0.341 & 0.307 & 0.186 & 0.255 & 0.408 & 0.468 & 0.500 \\
\hline $\mathrm{La}$ & - & 0.006 & - & - & - & - & - \\
\hline $\mathrm{Ce}$ & 0.007 & 0.005 & - & - & - & - & 0.006 \\
\hline $\operatorname{Pr}$ & - & - & - & - & - & 0.004 & - \\
\hline $\mathrm{Nd}$ & - & - & - & - & - & - & 0.006 \\
\hline $\mathrm{Sm}$ & - & 0.007 & - & - & - & - & - \\
\hline $\mathrm{Eu}$ & - & 0.006 & - & - & - & 0.010 & 0.009 \\
\hline Gd & 0.011 & 0.005 & 0.007 & 0.009 & 0.022 & 0.031 & 0.027 \\
\hline Dy & 0.013 & 0.008 & 0.009 & 0.016 & 0.033 & 0.041 & 0.048 \\
\hline $\mathrm{Er}$ & 0.028 & 0.027 & 0.011 & 0.017 & 0.025 & 0.033 & 0.020 \\
\hline $\mathrm{Yb}$ & 0.046 & 0.049 & 0.019 & 0.037 & 0.014 & 0.017 & 0.012 \\
\hline$\Sigma$ cations & 8.16 & 8.13 & 8.07 & 8.08 & 8.10 & 8.13 & 8.14 \\
\hline
\end{tabular}

$\mathrm{eO}^{*}=$ total iron as $\mathrm{Fe}^{2+} ; \mathrm{bdl}=$ below detection limit; $N=$ number of analyses averaged. $\mathrm{PbO}, \mathrm{SrO}, \mathrm{MgO}, \mathrm{Al}_{2} \mathrm{O}_{3}=$ bdl. 


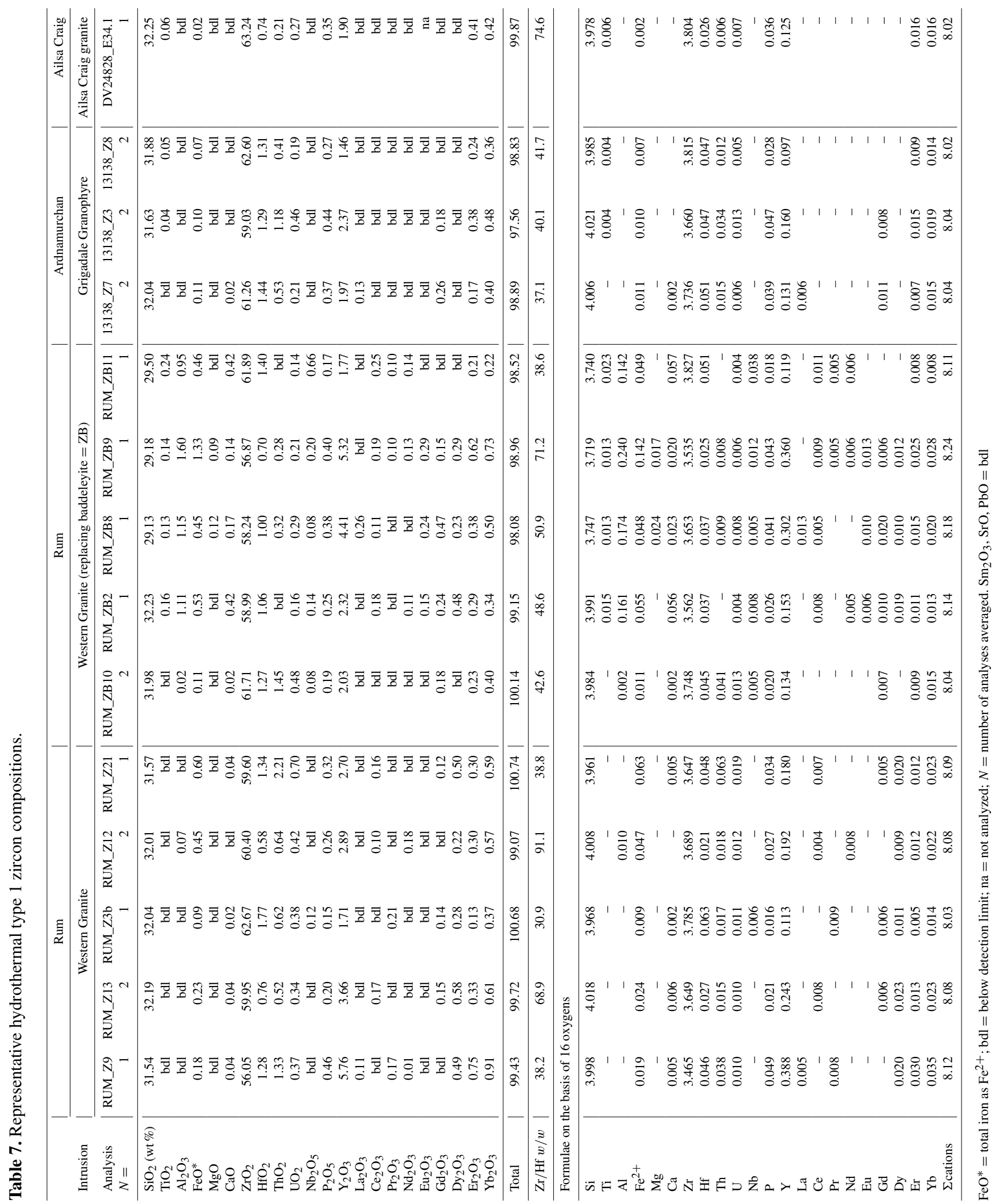




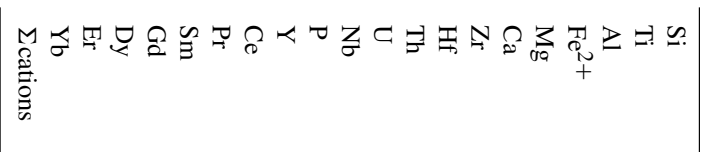

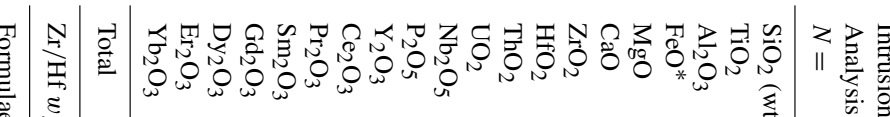

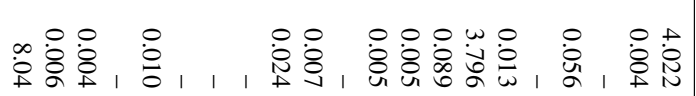

싱

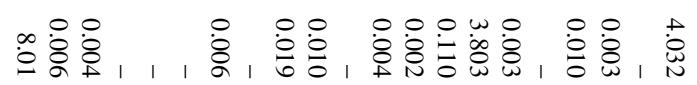

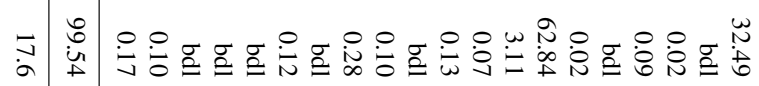

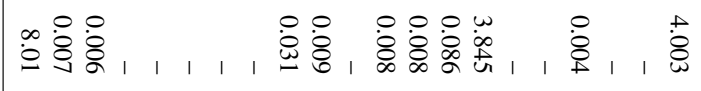

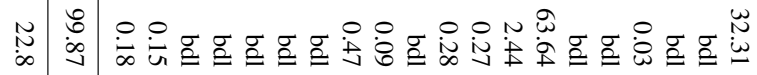
(2)

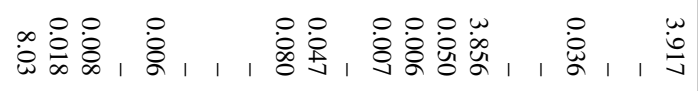

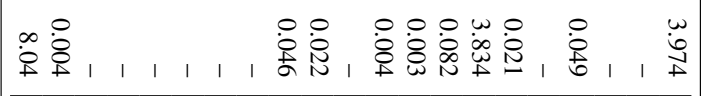

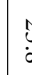

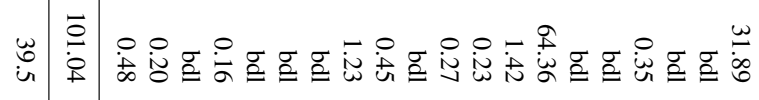

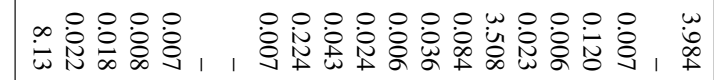

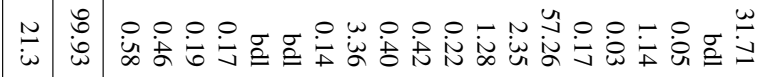

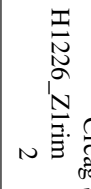

党.

芯

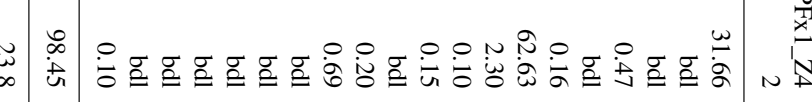

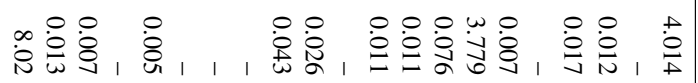

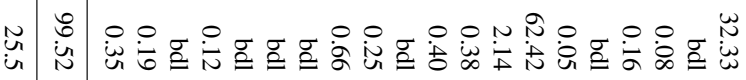

党

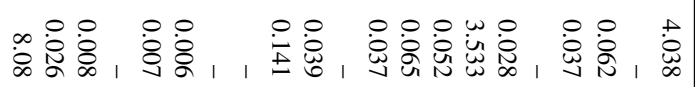

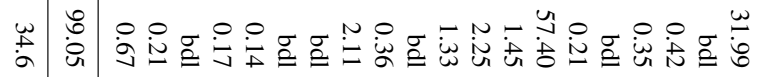

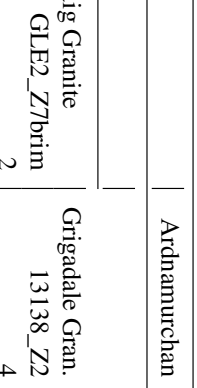

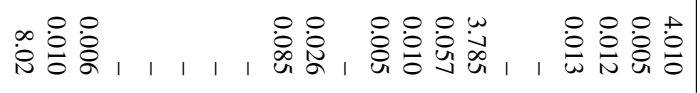

芦 

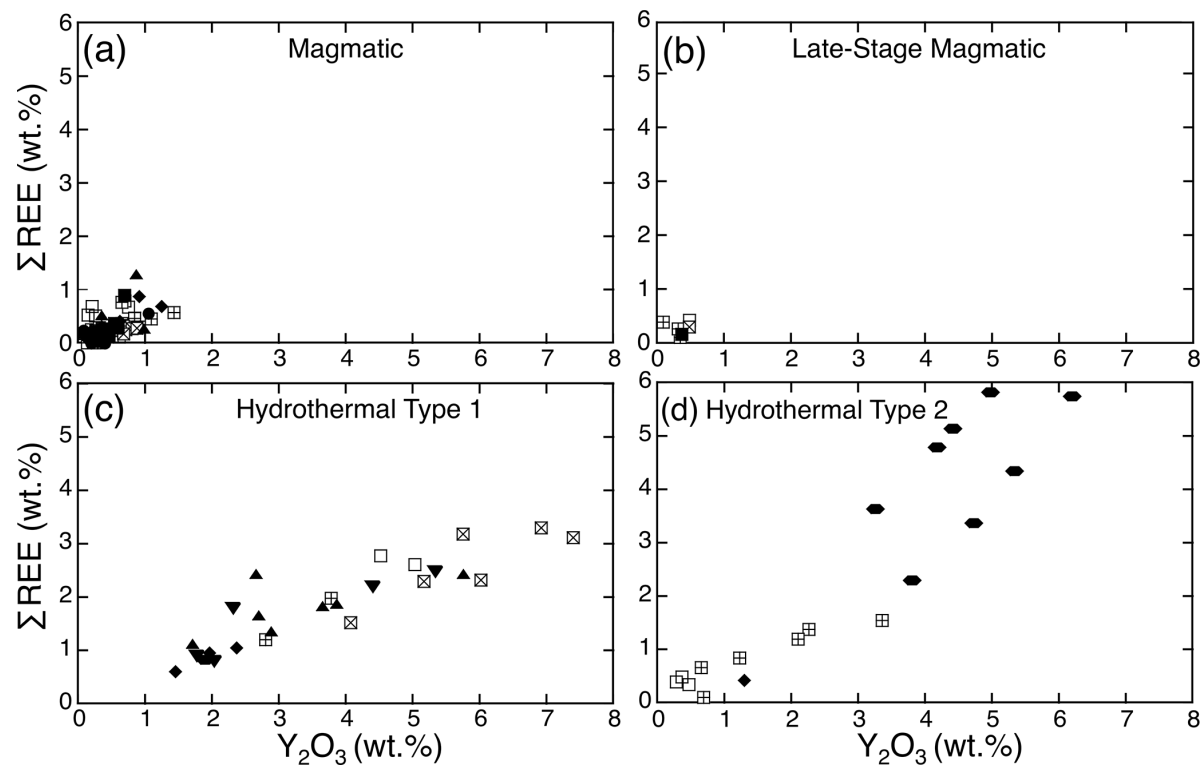

Figure 5. Variation in $\mathrm{Y}_{2} \mathrm{O}_{3}$ versus $\Sigma \mathrm{REE}$ (wt \%) in the studied zircons: (a) magmatic, (b) late-stage magmatic, (c) hydrothermal type 1, and (d) hydrothermal type 2 .
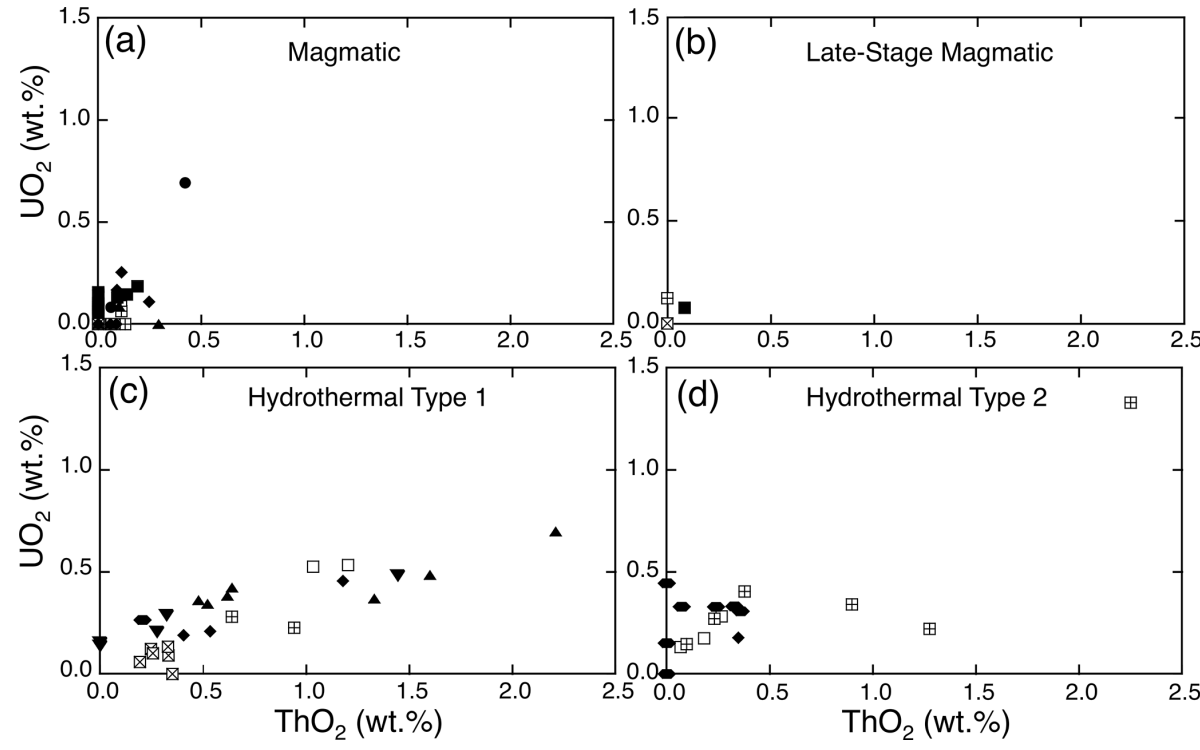

Figure 6. Variation in $\mathrm{ThO}_{2}$ versus $\mathrm{UO}_{2}(\mathrm{wt} \%$ ) in the studied zircons: (a) magmatic, (b) late-stage magmatic, (c) hydrothermal type 1, and (d) hydrothermal type 2 .

\section{Results - modes of occurrence and compositions of other Zr-bearing minerals}

\subsection{Baddeleyite}

Baddeleyite was identified in two samples from Ardnamurchan (Granophyre, Centre 2, sample 14724, and the Grigadale Granophyre, 13138) and in the Rum Western Granite (RUM). In all three, it is abundant - more than 50 crystals per section. Baddeleyite occurs as thin isolated blades (Fig. 10a, b), as radiating clusters (Fig. 10c), and as residual crystals from baddeleyite $\rightarrow$ zircon reactions (Fig. 10d). It also occurs, but less frequently, as a site for zirconolite precipitation (Fig. 10e, g). The majority of crystals in all three samples are small, typically $1-3 \mu \mathrm{m}$ wide blades, and enclosed mainly in quartz (Fig. 10a) and feldspar (Fig. 10b).

The Rum and Ardnamurchan samples have textures that demonstrate various stages of baddeleyite reaction to zircon, from small zircon patches in baddeleyite (Fig. 10c) to residual baddeleyite amongst zircon (Fig. 10d). One case shows 

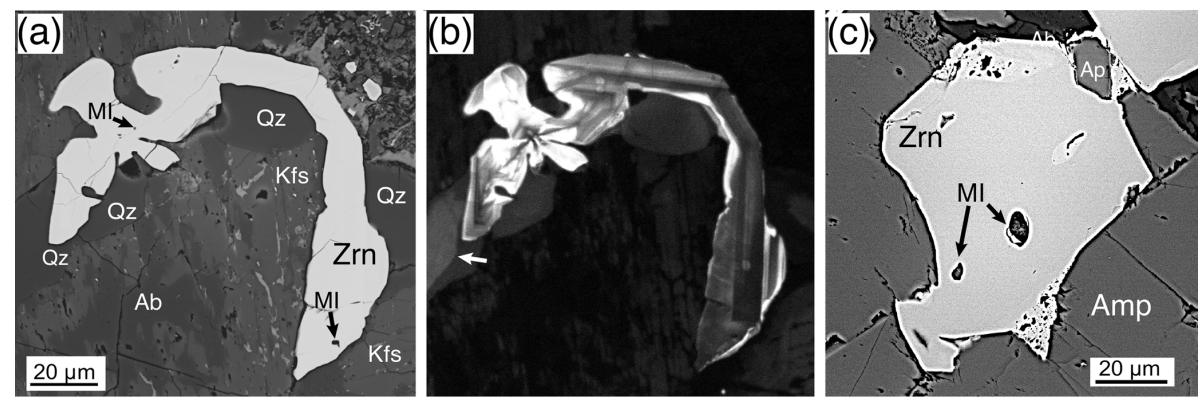

Figure 7. Late-stage magmatic zircons, BSE images except where noted. (a) A $200 \mu \mathrm{m}$ zircon (Zrn) filling an irregular space among quartz (Qz), albite (Ab), and K-feldspar (Kfs), with silicate-melt inclusions (MI). Mull, Toll Doire Granophyre, sample 44858. (b) A CL image of (a) showing typical magmatic zoning. The arrow shows the more CL-active core of a quartz grain. (c) A $100 \mu \mathrm{m}$ zircon (Zrn) filling an irregular space in amphibole (Amp), silicate-melt inclusions (MIs), and apatite (Ap). Skye, Western Red Hills Centre, Loch Ainort Granite, sample H1554.
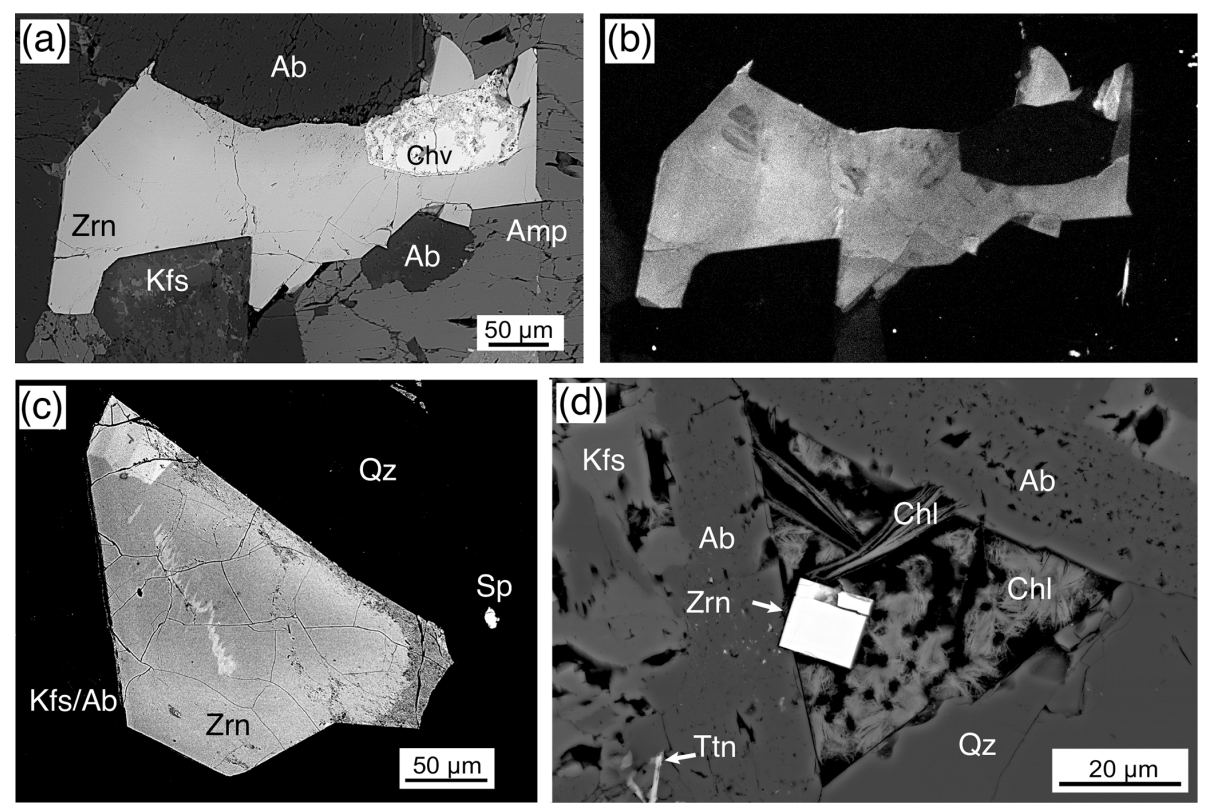

Figure 8. Hydrothermal type 1 zircons, BSE images except where noted. (a) A $450 \mu \mathrm{m}$ zircon (Zrn) filling a space among amphibole (Amp), albite (Ab), and K-feldspar (Kfs). The zircon grew around a partially altered euhedral chevkinite-(Ce) (Chv). Skye, Strath na Creitheach Centre, Ruadh Stac Granite, sample RS1. (b) A CL image of (a) showing a mottled pattern. (c) A 250 um zircon (Zrn) filling a space between quartz (Qz), K-feldspar, and albite (Kfs/Ab). Skye, Strath na Creitheach Centre, Ruadh Stac Granite, sample RS1. (d) A $12 \mu \mathrm{m}$ euhedral zircon $(\mathrm{Zrn})$ in a triangular cavity partially filled with chlorite (Chl). The cavity is formed by inclusion-rich albite (Ab) and K-feldspar with quartz (Qz) and titanite (Ttn). Rum, Western Granite, sample RUM.

the remains of a zirconolite-baddeleyite pair in a late-stage zircon (Fig. 10e). The zircon composition and texture show it to be of late-stage hydrothermal origin.

Their small size, very thin habit, and common rounded surface from polishing rendered most EPMA experiments invalid due to the excitation volume interacting with host phases, secondary fluorescence, and instrument geometry problems. For example, Lumpkin (1999) suggests that many reported elements, such as $\mathrm{Si}, \mathrm{Al}$, and $\mathrm{Ca}$, may be overestimated from electron beam-host interaction, and we cannot preclude that some of our element data result from such an interaction. There are significant concentrations in the UK baddeleyite of $\mathrm{Nb}_{2} \mathrm{O}_{5}(\leq 2.95 \mathrm{wt} \%)$ and $\mathrm{TiO}_{2}(\leq 1.96 \mathrm{wt} \%)$ (Table 10). The presence of $\mathrm{Nb}^{5+}$ and $\mathrm{Ta}^{5+}$ requires a charge balanced substitution, such as $3 \mathrm{Zr} \leftrightarrow 2(\mathrm{Nb}, \mathrm{Ta})+(\mathrm{Mg}, \mathrm{Fe})$ (Lumpkin, 1999), as with the other identified $2^{+}$and $3^{+}$elements. A limited number of REEs were determined here, and all values were $<1 \mathrm{wt} \%$ and many at the detection limit, hence having a greater uncertainty than those elements $>1 \mathrm{wt} \%$. Other instrumentation, such as laser ablation (LA) ICP-MS would yield better detection limits, although NanoSIMS may be the instrument of choice considering their 

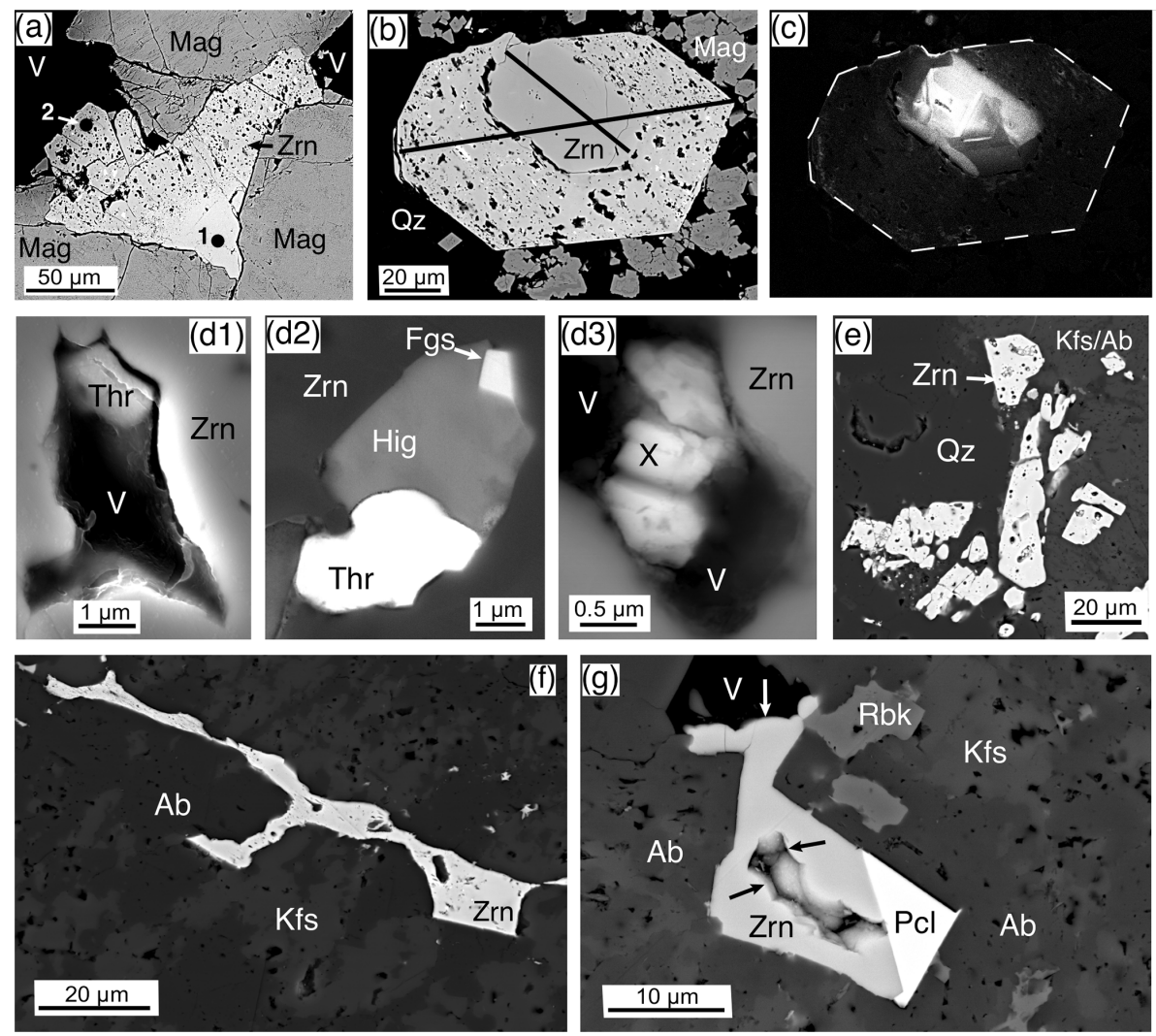

Figure 9. Hydrothermal type 2 zircons, BSE images except where noted. (a) A $175 \mu$ m zircon (Zrn) filling a space between magnetite (Mag) and vugs (V) that shows the transition between type 1 (pt. 1) and type 2 (pt. 2) hydrothermal zircon. Skye, Eastern Red Hills Centre, Creag Strollamus Granite, sample H1226. (b) A $120 \mu \mathrm{m}$ euhedral zircon (Zrn) composed of an outer hydrothermal type 2 portion, filled with inclusions (e.g., calcite, REE+Y fluorcarbonate, xenotime, thorite, chlorite) around a euhedral magmatic zircon. The two crystals are inclined $\sim 50^{\circ}$ (solid lines) and enclosed by quartz (Qz) and magnetite (Mag). Skye, Western Red Hills Centre, (Northern) Porphyritic Felsite, sample NPF (sheared) \#1. (c) CL image of (b) showing a cathodoluminescence-zoned magmatic center with a weak or non-CL hydrothermal portion. Barely visible bright spots in the outer portion are thorite and REE+Y fluorcarbonate. $(\mathbf{d 1}, \mathbf{2 , 3})$ Inclusions in hydrothermal type 2 zircon (Zrn): (d1) thorite (Thr) inclusion from sample NPF sheared \#1, void (V) space, SE image; (d2) inclusion composed of fergusonite (Fgs), thorite (Thr), and probable hingganite-(Y), sample H1226; and (d3) inclusion composed of three electron beam-sensitive crystals of an unknown U,Y,Si carbonate, dark areas are void (V) space, sample H1226. (e) A group of inclusion-filled zircons (Zrn) at a quartz(Qz) and K-feldspar-albite (Kfs/Ab) boundary, and many inclusions contain thorite. Skye, Western Red Hills Centre, Glamaig Granite, sample GLE2. (f) A $100 \mu \mathrm{m}$ inclusion-filled zircon (Zrn) that formed in a gap in K-feldspar (Kfs) and albite (Ab). Skye, Western Red Hills Centre, Maol na Gainmich Granite, sample 14709. (g) A $30 \mu \mathrm{m}$ zircon (Zrn) filling a vug (V) after the precipitation of fluornatropyrochlore (Pcl). The cavity in the zircon has a botryoidal surface (black arrows), as well as the upper portion (white arrow). The Zrn and Pcl are enclosed by $\mathrm{K}$-feldspar (Kfs) and albite (Ab) accompanied by riebeckite (Rbk). Ailsa Craig microgranite, sample DV24828.

sizes observed in this study. Although most baddeleyite compositional studies in the literature do not include REEs, a few have reported REEs using either EPMA (e.g., Rajesh et al., 2006; Tropper et al., 2007; Huraiová et al., 2011; Zhao et al., 2016) or LA-ICP-MS (e.g., Schärer et al., 2011; Zhang et al., 2017) techniques. In all cases, the $\Sigma$ REE content is very minor, $\leq 1 \mathrm{wt} \%-1.5 \mathrm{wt} \%$.

\subsection{Zirconolite}

Zirconolite, ideally $\mathrm{CaZrTi}_{2} \mathrm{O}_{7}$, was identified only in the Ardnamurchan and Glamaig samples. The Glamaig zirconolite was analyzed by EPMA during a study focused on chevkinite-group minerals (Macdonald et al., 2013a). No description of the texture or petrographic relations of the GLE2 occurrence is available; nevertheless, we include two analyses in Table 11. In the Ardnamurchan samples, zirconolite forms small, $\leq 10 \mu \mathrm{m}$, anhedral to subhedral crystals frequently intergrown with other phases, such as britholite (Fig. 10f), baddeleyite (Fig. 10g), and zircon (Fig. 10h). Most crystals are $\leq 5 \mu \mathrm{m}$. Zirconolite in the Ardnamurchan samples is weakly CL active, and there was no zoning observed in either CL or BSE imaging.

Three polytypes of zirconolite have been described: zirconolite-2 $M$, a monoclinic two-layered structure, zirconolite-3O, an orthorhombic three-layered structure, and 
Table 9. Hydrothermal type 2 zircon compositions from Ailsa Craig microgranite.

\begin{tabular}{|c|c|c|c|c|c|c|c|c|}
\hline \multirow{3}{*}{$\begin{array}{l}\text { Analysis } \\
N=\end{array}$} & \multicolumn{8}{|c|}{ Ailsa Craig sample DV24828 } \\
\hline & EZ16.1 & EZ25.1 & EZ35.1 & EZ36.1 & EZ36.2 & EZ37.1 & EZ38.1 & EZ39.1 \\
\hline & 1 & 1 & 1 & 1 & 1 & 1 & 1 & 1 \\
\hline $\mathrm{SiO}_{2}(\mathrm{wt} \%)$ & 32.20 & 29.93 & 29.81 & 30.79 & 30.57 & 28.16 & 31.06 & 32.22 \\
\hline $\mathrm{TiO}_{2}$ & 0.42 & 0.71 & 0.92 & 0.57 & 0.52 & 0.68 & 0.35 & 0.40 \\
\hline $\mathrm{Al}_{2} \mathrm{O}_{3}$ & 1.15 & 1.78 & 1.21 & 1.28 & 1.44 & 1.99 & 1.13 & 1.27 \\
\hline $\mathrm{FeO}^{*}$ & 1.34 & 1.16 & 1.16 & 1.42 & 1.32 & 0.58 & 1.17 & 1.08 \\
\hline $\mathrm{MnO}$ & 0.11 & 0.07 & 0.17 & 0.09 & 0.04 & 0.02 & 0.12 & 0.09 \\
\hline $\mathrm{MgO}$ & bdl & bdl & bdl & bdl & 0.41 & 0.24 & bdl & bdl \\
\hline $\mathrm{CaO}$ & 2.37 & 0.99 & 2.05 & 2.82 & 2.47 & 1.09 & 3.22 & 2.94 \\
\hline $\mathrm{K}_{2} \mathrm{O}$ & 0.03 & 0.03 & bdl & bdl & 0.18 & 0.08 & 0.20 & 0.13 \\
\hline $\mathrm{ZrO}_{2}$ & 47.65 & 45.17 & 44.43 & 49.52 & 46.78 & 45.79 & 39.84 & 39.85 \\
\hline $\mathrm{HfO}_{2}$ & 1.14 & 1.16 & 0.95 & 1.00 & 1.06 & 1.26 & 0.91 & 1.06 \\
\hline $\mathrm{ThO}_{2}$ & bdl & bdl & 0.24 & bdl & 0.36 & bdl & 0.07 & 0.33 \\
\hline $\mathrm{UO}_{2}$ & bdl & bdl & 0.33 & 0.45 & 0.31 & 0.15 & 0.33 & 0.33 \\
\hline $\mathrm{Nb}_{2} \mathrm{O}_{5}$ & 0.41 & 1.00 & 1.53 & 0.89 & 0.72 & 0.88 & 2.56 & 2.33 \\
\hline $\mathrm{Ta}_{2} \mathrm{O}_{5}$ & 0.22 & bdl & bdl & 0.38 & 0.22 & bdl & 0.09 & 0.30 \\
\hline $\mathrm{P}_{2} \mathrm{O}_{5}$ & 0.18 & 3.50 & 1.29 & 0.21 & 0.39 & 3.17 & 0.09 & 0.02 \\
\hline $\mathrm{Y}_{2} \mathrm{O}_{3}$ & 3.26 & 4.42 & 5.34 & 3.81 & 4.73 & 4.18 & 4.98 & 6.20 \\
\hline $\mathrm{La}_{2} \mathrm{O}_{3}$ & 0.60 & 0.59 & 0.17 & 0.18 & 0.18 & 0.38 & 0.77 & 0.55 \\
\hline $\mathrm{Ce}_{2} \mathrm{O}_{3}$ & 1.11 & 1.68 & 0.71 & 0.43 & 0.53 & 1.84 & 1.16 & 1.19 \\
\hline $\mathrm{Pr}_{2} \mathrm{O}_{3}$ & 0.10 & 0.46 & 0.10 & bdl & bdl & 0.25 & 0.17 & 0.10 \\
\hline $\mathrm{Nd}_{2} \mathrm{O}_{3}$ & 0.44 & 0.84 & 0.62 & 0.29 & bdl & 0.68 & 0.74 & 1.01 \\
\hline $\mathrm{Sm}_{2} \mathrm{O}_{3}$ & 0.29 & 0.38 & 0.12 & bdl & 0.28 & 0.28 & 0.16 & 0.49 \\
\hline $\mathrm{Gd}_{2} \mathrm{O}_{3}$ & 0.12 & 0.19 & 0.73 & 0.13 & 0.65 & 0.29 & 0.70 & 0.47 \\
\hline $\mathrm{Dy}_{2} \mathrm{O}_{3}$ & 0.49 & 0.47 & 0.99 & 0.61 & 0.84 & 0.39 & 0.89 & 0.95 \\
\hline $\mathrm{Er}_{2} \mathrm{O}_{3}$ & 0.41 & 0.38 & 0.43 & 0.43 & 0.58 & 0.40 & 0.78 & 0.65 \\
\hline $\mathrm{Yb}_{2} \mathrm{O}_{3}$ & 0.11 & 0.14 & 0.48 & 0.23 & 0.30 & 0.27 & 0.45 & 0.34 \\
\hline $\mathrm{Cl}$ & 0.20 & 0.07 & bdl & bdl & 0.08 & 0.17 & bdl & bdl \\
\hline$-\mathrm{O} \equiv \mathrm{Cl}$ & 0.05 & 0.01 & - & - & 0.02 & 0.04 & - & - \\
\hline Total & 94.30 & 95.11 & 93.75 & 95.51 & 94.94 & 93.17 & 91.93 & 94.29 \\
\hline $\mathrm{Zr} / \mathrm{Hf} w / w$ & 36.4 & 34.1 & 41.0 & 43.4 & 38.5 & 31.7 & 38.2 & 32.8 \\
\hline \multicolumn{9}{|c|}{ Formulae on the basis of 16 oxygens } \\
\hline $\mathrm{Si}$ & 4.167 & 3.808 & 3.924 & 3.971 & 3.980 & 3.690 & 4.178 & 4.220 \\
\hline $\mathrm{Ti}$ & 0.041 & 0.068 & 0.091 & 0.056 & 0.051 & 0.067 & 0.035 & 0.040 \\
\hline $\mathrm{Al}$ & 0.175 & 0.267 & 0.187 & 0.194 & 0.221 & 0.307 & 0.178 & 0.196 \\
\hline $\mathrm{Fe}^{2+}$ & 0.145 & 0.123 & 0.127 & 0.153 & 0.144 & 0.063 & 0.131 & 0.118 \\
\hline $\mathrm{Mn}$ & 0.012 & 0.008 & 0.019 & 0.009 & 0.005 & 0.002 & 0.014 & 0.010 \\
\hline $\mathrm{Mg}$ & - & - & - & - & 0.079 & 0.046 & - & - \\
\hline $\mathrm{Ca}$ & 0.329 & 0.135 & 0.289 & 0.390 & 0.345 & 0.152 & 0.464 & 0.413 \\
\hline K & 0.004 & 0.005 & - & - & 0.029 & 0.013 & 0.034 & 0.021 \\
\hline $\mathrm{Zr}$ & 3.007 & 2.803 & 2.852 & 3.115 & 2.970 & 2.926 & 2.613 & 2.545 \\
\hline $\mathrm{Hf}$ & 0.042 & 0.042 & 0.036 & 0.037 & 0.039 & 0.047 & 0.035 & 0.040 \\
\hline Th & - & - & 0.007 & - & 0.011 & - & 0.002 & 0.010 \\
\hline $\mathrm{U}$ & - & - & 0.010 & 0.013 & 0.009 & 0.004 & 0.010 & 0.010 \\
\hline $\mathrm{Nb}$ & 0.024 & 0.057 & 0.091 & 0.052 & 0.042 & 0.052 & 0.156 & 0.138 \\
\hline $\mathrm{Ta}$ & 0.008 & - & - & 0.013 & 0.008 & - & 0.003 & 0.011 \\
\hline $\mathrm{P}$ & 0.019 & 0.377 & 0.144 & 0.023 & 0.043 & 0.352 & 0.010 & 0.002 \\
\hline $\mathrm{Y}$ & 0.224 & 0.299 & 0.374 & 0.261 & 0.327 & 0.291 & 0.356 & 0.432 \\
\hline $\mathrm{La}$ & 0.029 & 0.028 & 0.008 & 0.008 & 0.009 & 0.018 & 0.038 & 0.026 \\
\hline $\mathrm{Ce}$ & 0.052 & 0.078 & 0.034 & 0.020 & 0.025 & 0.088 & 0.057 & 0.057 \\
\hline $\operatorname{Pr}$ & 0.005 & 0.021 & 0.005 & - & - & 0.012 & 0.008 & 0.005 \\
\hline $\mathrm{Nd}$ & 0.020 & 0.038 & 0.029 & 0.013 & - & 0.032 & 0.036 & 0.047 \\
\hline $\mathrm{Sm}$ & 0.013 & 0.017 & 0.005 & - & 0.012 & 0.013 & 0.007 & 0.022 \\
\hline $\mathrm{Gd}$ & 0.005 & 0.008 & 0.032 & 0.006 & 0.028 & 0.013 & 0.031 & 0.021 \\
\hline Dy & 0.020 & 0.019 & 0.042 & 0.025 & 0.035 & 0.016 & 0.038 & 0.040 \\
\hline Er & 0.017 & 0.015 & 0.018 & 0.017 & 0.024 & 0.016 & 0.033 & 0.027 \\
\hline $\mathrm{Yb}$ & 0.004 & 0.006 & 0.019 & 0.009 & 0.012 & 0.011 & 0.018 & 0.014 \\
\hline $\mathrm{Cl}$ & 0.044 & 0.014 & - & - & 0.017 & 0.038 & - & - \\
\hline Total & 8.41 & 8.24 & 8.34 & 8.39 & 8.47 & 8.27 & 8.49 & 8.46 \\
\hline
\end{tabular}

$\mathrm{FeO}^{*}=$ total iron as $\mathrm{Fe}^{2+} ;$ bdl $=$ below detection limit; $N=$ number of analyses averaged. $\mathrm{PbO}, \mathrm{SrO}=$ not analyzed. 

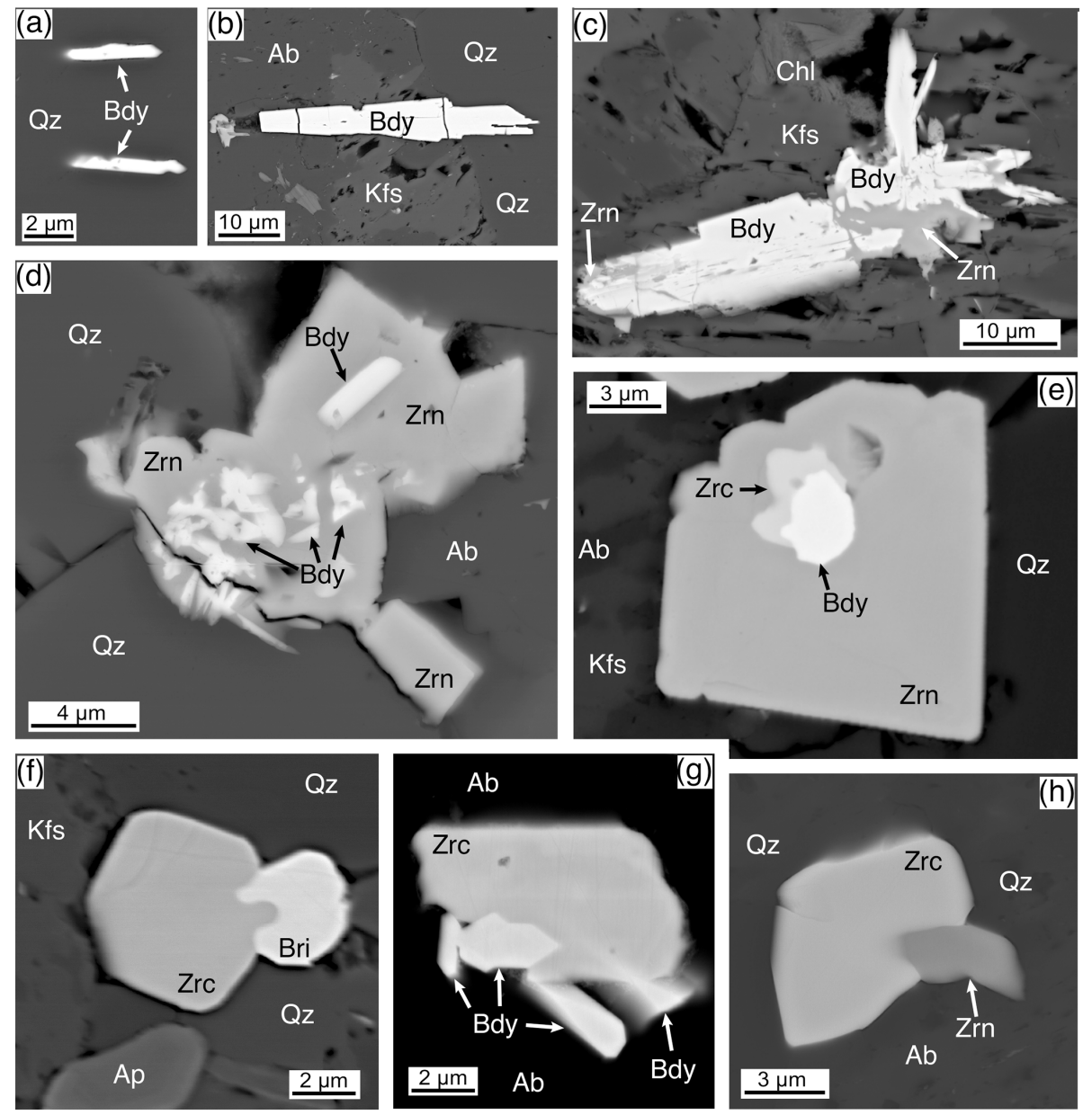

Figure 10. Baddeleyite and zirconolite, BSE images. (a) Two doubly terminated blades of baddeleyite (Bdy) enclosed in quartz (Qz). Rum, Western Granite, sample RUM. (b) A $50 \mu \mathrm{m}$ blade of baddeleyite (Bdy) imbedded in quartz (Qz), albite (Ab), and K-feldspar (Kfs). A small portion on the left side of the blade has been plucked out. Rum, Western Granite, sample RUM. (c) A $50 \mu \mathrm{m}$ baddeleyite (Bdy) blade, in part with radiating blades, in K-feldspar (Kfs) and chlorite (Chl). Zircon (Zrn) is replacing the baddeleyite on the lower-right and upper-left ends. Rum, Western Granite, sample RUM. (d) A residual mass of baddeleyite (Bdy) that has been replaced and overgrown by zircon (Zrn), enclosed by quartz (Qz) and albite (Ab). Rum, Western Granite, sample RUM. (e) Small $\sim 1 \mu \mathrm{m}$ crystals of zirconolite (Zrc) growing on a $3 \mu \mathrm{m}$ baddeleyite (Bdy), both enclosed by a $17 \mu \mathrm{m}$ euhedral zircon (Zrn) enclosed by quartz (Qz), albite (Ab), and Kfeldspar (Kfs). Ardnamurchan, Grigadale Granophyre, sample 13138. (f) A $6 \mu$ m euhedral zirconolite (Zrc) with a coeval, at least on the rim, britholite-(Ce)(Bri). Surrounded by quartz (Qz) and K-feldspar (Kfs) with a zoned apatite (Ap) to the lower left. Ardnamurchan, Grigadale Granophyre, sample 13138. (g) An $8 \mu \mathrm{m}$ subhedral zirconolite ( $\mathrm{Zrc}$ ) with adjacent and embedded baddeleyite (Bdy), enclosed by albite (Ab). Ardnamurchan, Granophyre, Centre 2, sample 14724. (h) A $10 \mu \mathrm{m}$ subhedral zirconolite (Zrc) that has partially grown over a $3 \mu \mathrm{m}$ zircon (Zrn), enclosed by quartz (Qz) and albite $(\mathrm{Ab})$. Ardnamurchan, Grigadale Granophyre, sample 13138.

zirconolite-3T, a three-layered trigonal structure; two other polytypes, $4 M$ and $6 T$, have been described as supercells of the $2 M$ and $3 T$ polytypes, respectively (for a detailed crystallographic discussion see Mazzi and Munno, 1983; White, 1984; Bayliss et al., 1989; Smith and Lumpkin, 1993; Coelho et al., 1997). We have no structural data and the crystal shapes do not suggest any particular polytype.

Although the nominal zirconolite formula is simple $\left(\mathrm{CaZrTi}_{2} \mathrm{O}_{7}\right)$, the composition in natural samples is complex and exhibits extensive element substitution as a function of both host rock and paragenesis (e.g., Williams and
Gieré, 1996; Gieré et al., 1998). In an attempt to classify and understand the various element substitution schemes, Gieré et al. (1998) defined five zirconolite end-members: $\mathrm{CaZrTi}_{2} \mathrm{O}_{7}, \quad \mathrm{CaZrMe}^{5+} \mathrm{Me}^{3+} \mathrm{O}_{7}, \quad$ REEZrTiMe $^{3+} \mathrm{O}_{7}$, REEZrMe ${ }^{5+} \mathrm{Me}^{2+} \mathrm{O}_{7}$, and $\mathrm{ACTZrTiMe}^{2+} \mathrm{O}_{7}$, where $\mathrm{Me}^{2+}=\mathrm{Mg}^{2+}+\mathrm{Fe}^{2+}+\mathrm{Mn}^{2+}+\mathrm{Zn}^{2+} ; \mathrm{Me}^{3+}=\mathrm{Al}^{3+}+$ $\mathrm{Fe}^{3+}+\mathrm{Cr}^{3+} ; \mathrm{Me}^{5+}=\mathrm{Nb}^{5+}+\mathrm{Ta}^{5+} ; \mathrm{REE}=\mathrm{Ln}^{3+}+\mathrm{Y}^{3+}$; and $\mathrm{ACT}=\mathrm{U}^{4+}+\mathrm{Th}^{4+}$. Three structural sites can show extensive substitution: $\mathrm{M} 8=\Sigma(\mathrm{REE}+\mathrm{Y})+\Sigma(\mathrm{U}+\mathrm{Th})+\mathrm{Ca}$; $\mathrm{M} 5,6=\Sigma \mathrm{Mg}+\mathrm{Fe}^{\text {total }}+\mathrm{Al}+\Sigma(\mathrm{Nb}+\mathrm{Ta})+\mathrm{W}+\mathrm{Ti} ;$ and $\mathrm{M} 7$ $=\Sigma(\mathrm{Zr}+\mathrm{Hf})$. However, Gieré et al. (1998) pointed out 
Table 10. Compositions of baddeleyite.

\begin{tabular}{|c|c|c|c|c|c|c|c|c|c|c|c|}
\hline \multirow{4}{*}{$\begin{array}{l}\text { Intrusion } \\
\text { Analysis } \\
N=\end{array}$} & \multicolumn{5}{|c|}{ Ardnamurchan } & \multicolumn{6}{|c|}{ Rum } \\
\hline & \multicolumn{4}{|c|}{ Grigadale Granophyre } & \multirow{2}{*}{$\begin{array}{r}\text { Grano. Cen. } 2 \\
\text { 14724_B4 }\end{array}$} & \multicolumn{6}{|c|}{ Western Granite } \\
\hline & 13138_B4 & 13138_B2a & 13138_B2b & 13138_B2c & & RUM_B2a & RUM_B2b & RUM_B2.2 & RUM_B1a & RUM_B7a & RUM_B7b \\
\hline & 1 & 1 & 1 & 1 & 1 & 2 & 4 & 1 & 1 & 1 & 1 \\
\hline $\mathrm{SiO}_{2}(\mathrm{wt} \%)$ & bdl & bdl & 0.04 & bdl & 1.02 & 0.40 & 0.31 & 0.39 & 0.33 & 0.93 & bdl \\
\hline $\mathrm{TiO}_{2}$ & 0.78 & 0.35 & 0.69 & 0.40 & 0.47 & 1.92 & 1.96 & 1.96 & 0.76 & 1.05 & 1.00 \\
\hline $\mathrm{Al}_{2} \mathrm{O}_{3}$ & bdl & bdl & bdl & bdl & 0.25 & 0.09 & 0.03 & 0.13 & 0.44 & 0.96 & 0.53 \\
\hline $\mathrm{FeO}^{*}$ & 0.51 & 0.12 & 0.20 & 0.17 & 3.07 & 0.84 & 0.79 & 0.95 & 0.36 & 3.65 & 2.33 \\
\hline $\mathrm{MgO}$ & bdl & bdl & bdl & bdl & bdl & bdl & bdl & bdl & bdl & 0.08 & bdl \\
\hline $\mathrm{CaO}$ & 0.02 & 0.02 & bdl & bdl & bdl & 0.04 & bdl & bdl & 0.16 & 0.04 & 0.05 \\
\hline $\mathrm{ZrO}_{2}$ & 95.84 & 95.13 & 97.34 & 96.66 & 85.74 & 91.38 & 90.51 & 90.42 & 92.45 & 88.41 & 90.02 \\
\hline $\mathrm{HfO}_{2}$ & 1.31 & 3.47 & 1.08 & 1.06 & 4.08 & 1.58 & 1.62 & 1.71 & 1.74 & 1.75 & 1.80 \\
\hline $\mathrm{ThO}_{2}$ & bdl & bdl & bdl & bdl & bdl & 0.09 & 0.17 & 0.09 & bdl & bdl & bdl \\
\hline $\mathrm{UO}_{2}$ & 0.06 & 0.12 & 0.14 & bdl & bdl & 0.23 & 0.34 & 0.25 & 0.41 & 0.28 & bdl \\
\hline $\mathrm{Nb}_{2} \mathrm{O}_{5}$ & 1.07 & 0.44 & 0.80 & 0.94 & 2.07 & 2.72 & 2.95 & 2.97 & 0.86 & 1.76 & 1.80 \\
\hline $\mathrm{Y}_{2} \mathrm{O}_{3}$ & 0.42 & bdl & 0.10 & 0.26 & 0.18 & 0.43 & 0.41 & 0.40 & 1.29 & 0.31 & 0.23 \\
\hline $\mathrm{La}_{2} \mathrm{O}_{3}$ & bdl & bdl & bdl & 0.12 & bdl & bdl & bdl & bdl & bdl & bdl & bdl \\
\hline $\mathrm{Ce}_{2} \mathrm{O}_{3}$ & 0.13 & bdl & bdl & bdl & bdl & bdl & bdl & bdl & bdl & bdl & bdl \\
\hline $\mathrm{Pr}_{2} \mathrm{O}_{3}$ & bdl & bdl & bdl & 0.24 & bdl & 0.12 & 0.10 & 0.25 & bdl & bdl & bdl \\
\hline $\mathrm{Nd}_{2} \mathrm{O}_{3}$ & 0.24 & bdl & bdl & bdl & bdl & 0.16 & 0.10 & 0.13 & 0.10 & bdl & bdl \\
\hline $\mathrm{Sm}_{2} \mathrm{O}_{3}$ & bdl & 0.17 & bdl & bdl & bdl & bdl & bdl & bdl & 0.23 & bdl & bdl \\
\hline $\mathrm{Dy}_{2} \mathrm{O}_{3}$ & bdl & 0.20 & bdl & 0.21 & 0.19 & bdl & 0.15 & bdl & 0.15 & bdl & bdl \\
\hline $\mathrm{Er}_{2} \mathrm{O}_{3}$ & bdl & bdl & bdl & bdl & 0.10 & 0.23 & 0.14 & 0.29 & 0.24 & bdl & bdl \\
\hline $\mathrm{Yb}_{2} \mathrm{O}_{3}$ & 0.15 & bdl & bdl & bdl & bdl & 0.17 & 0.22 & 0.11 & 0.17 & bdl & 0.35 \\
\hline Total & 100.52 & 100.02 & 100.38 & 100.04 & 97.17 & 100.40 & 99.79 & 100.05 & 99.69 & 99.22 & 98.11 \\
\hline \multicolumn{12}{|c|}{ Formulae on the basis of four oxygens } \\
\hline $\mathrm{Si}$ & - & - & 0.002 & - & 0.043 & 0.016 & 0.013 & 0.016 & 0.014 & 0.038 & - \\
\hline $\mathrm{Ti}$ & 0.024 & 0.011 & 0.021 & 0.012 & 0.015 & 0.058 & 0.060 & 0.060 & 0.024 & 0.032 & 0.031 \\
\hline $\mathrm{Al}$ & - & - & - & - & 0.013 & 0.004 & 0.002 & 0.006 & 0.021 & 0.046 & 0.026 \\
\hline $\mathrm{Fe}^{2+}$ & 0.017 & 0.004 & 0.007 & 0.006 & 0.109 & 0.028 & 0.027 & 0.032 & 0.012 & 0.124 & 0.081 \\
\hline $\mathrm{Mg}$ & - & - & - & - & - & - & - & - & - & 0.005 & - \\
\hline $\mathrm{Ca}$ & 0.001 & 0.001 & - & - & 0.001 & 0.002 & - & - & 0.007 & 0.002 & 0.002 \\
\hline $\mathrm{Zr}$ & 1.911 & 1.925 & 1.938 & 1.937 & 1.769 & 1.805 & 1.804 & 1.794 & 1.862 & 1.757 & 1.827 \\
\hline $\mathrm{Hf}$ & 0.015 & 0.041 & 0.013 & 0.012 & 0.049 & 0.018 & 0.019 & 0.020 & 0.021 & 0.020 & 0.021 \\
\hline $\mathrm{Th}$ & - & - & - & - & - & 0.001 & 0.002 & 0.001 & - & - & - \\
\hline $\mathrm{U}$ & 0.001 & 0.001 & 0.001 & - & - & 0.002 & 0.003 & 0.002 & 0.004 & 0.003 & - \\
\hline $\mathrm{Nb}$ & 0.020 & 0.008 & 0.015 & 0.017 & 0.040 & 0.050 & 0.055 & 0.055 & 0.016 & 0.032 & 0.034 \\
\hline $\mathrm{Y}$ & 0.009 & - & 0.002 & 0.006 & 0.004 & 0.009 & 0.009 & 0.009 & 0.028 & 0.007 & 0.005 \\
\hline $\mathrm{La}$ & - & - & - & 0.002 & - & - & - & - & - & - & - \\
\hline $\mathrm{Ce}$ & 0.002 & - & - & - & - & - & - & - & - & - & - \\
\hline $\operatorname{Pr}$ & - & - & - & 0.004 & - & 0.002 & 0.001 & 0.004 & - & - & - \\
\hline $\mathrm{Nd}$ & 0.003 & - & - & - & - & 0.002 & 0.001 & 0.002 & 0.001 & - & - \\
\hline $\mathrm{Sm}$ & - & 0.002 & - & - & - & - & - & - & 0.003 & - & - \\
\hline Dy & - & 0.003 & - & 0.003 & 0.003 & - & 0.002 & - & 0.002 & - & - \\
\hline $\mathrm{Er}$ & - & - & - & - & 0.001 & 0.003 & 0.002 & 0.004 & 0.003 & - & - \\
\hline $\mathrm{Yb}$ & 0.002 & - & - & - & - & 0.002 & 0.003 & 0.001 & 0.002 & - & 0.004 \\
\hline$\sum$ cations & 2.01 & 2.00 & 2.00 & 2.00 & 2.05 & 2.00 & 2.00 & 2.01 & 2.02 & 2.07 & 2.03 \\
\hline
\end{tabular}

$\mathrm{FeO}^{*}=$ total iron as $\mathrm{Fe}^{2+} ;$ bdl $=$ below detection limit; $N=$ number of analyses averaged. $\mathrm{PbO}, \mathrm{Eu}_{2} \mathrm{O}_{3}, \mathrm{Gd}_{2} \mathrm{O}_{3}=$ bdl.

that although only the $\mathrm{CaZrTi}_{2} \mathrm{O}_{7}$ and $\mathrm{CaZrMe}^{5+} \mathrm{Me}^{3+} \mathrm{O}_{7}$ end-members are found in nature, the others help define the various substitutions found in natural and synthetic zirconolites.

Given that most crystals in the granites are $\leq 5 \mu \mathrm{m}$ and/or intergrown with other phases, successful microprobe analysis was difficult. Zirconolites from both localities show extensive, but similar, substitutions, although our data set is limited. Furthermore, not all the REEs or all the elements suggested by Gieré et al. (1998) were determined. $\mathrm{CaO}$ in ideal $\mathrm{CaZrTi}_{2} \mathrm{O}_{7}$ is $16.5 \mathrm{wt} \%$, whereas in our study $\mathrm{CaO}$ varied from $2.90 \mathrm{wt} \%-5.34 \mathrm{wt} \%$ (Table 11). The deficiency in the M8 site is made up by REE $+\mathrm{Y}+\mathrm{U}+\mathrm{Th}$. Figure 11a shows a good negative correlation between $\mathrm{Ca}$ and REE+Y (apfu) for Ardnamurchan and Glamaig zirconolites. The new analyses are, in fact, notably (REE+Y)-rich, with $\mathrm{Y}$ being dominant. Zirconolites with such high $\mathrm{Y}_{2} \mathrm{O}_{3}$ values $(8.1 \mathrm{wt} \%$ $9.9 \mathrm{wt} \%$ ) are uncommon (Williams and Gieré, 1996) but have been recorded in a sapphirine granulite of the Vestfold Hills, East Antarctica (Harley, 1994). The Glamaig phase is also notably Nb-rich (0.190-0.245 apfu).

The Glamaig zirconolites are enriched in $\mathrm{U}$ and Th relative to the Ardnamurchan zirconolite, and the M8 site sum for both localities varies from 0.90-0.97 apfu. Except for one sample, Y dominates the M8 site; hence these are zirconolite(Y). Both the Ardnamurchan and Glamaig zirconolites have 

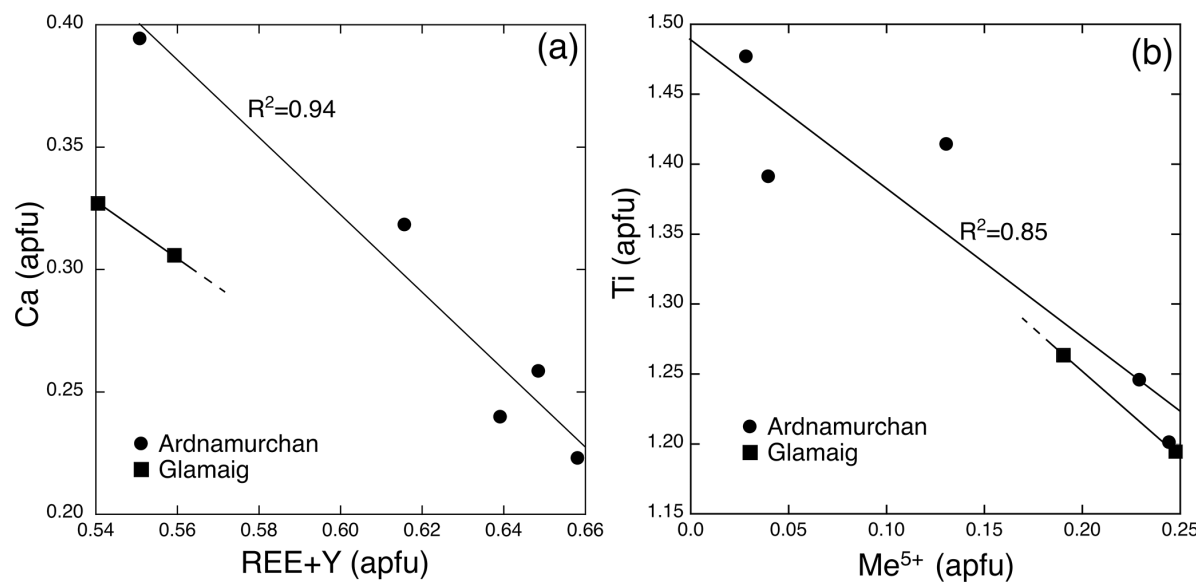

Figure 11. Chemical variation in zirconolite in atoms per formula unit, based on seven oxygens. (a) Variation in REE+Y versus Ca. A linear regression line for the Ardnamurchan data is shown. A line connecting the Glamaig data is also shown that suggests a similar slope to the Ardnamurchan data. (b) Variation in $\mathrm{Me}^{5+}$ versus Ti. A linear regression line for the Ardnamurchan data is shown. A line connecting the Glamaig data is also shown that suggests a similar slope to the Ardnamurchan data.

high total Fe and very low $\mathrm{Mg}$ and $\mathrm{Mn}$. There is a good negative correlation between $\mathrm{Me}^{5+}$ and $\mathrm{Ti}$ (Fig. 11b), although we only have one Ta determination (Table 11). This correlation suggests that the substitution $\mathrm{Me}^{5+}+\mathrm{Me}^{3+} \leftrightarrow 2 \mathrm{Ti}$ best describes the $\mathrm{Me}^{5+}$ relation and also suggests that most of the iron is ferric (Gieré et al. 1998).

The M8 site substitution for $\mathrm{Ca}$ is controlled by two factors: the ionic radius size and the abundance and diversity of potential cations in the environment of formation. A perusal of zirconolite databases such as Williams and Gieré (1996) shows the variability in REE $+Y$ values in terrestrial and lunar zirconolites. They have low values of $\mathrm{La}^{3+}$ and $\mathrm{Ce}^{3+}$ compared to common LREE-enriched phases such as monazite or chevkinite. The eight-coordinated M8 site does not readily accept cations larger than $\mathrm{Ca}^{2+}(r=0.112 \mathrm{~nm})$ (Smith and Lumpkin, 1993). The larger ionic radii of $\mathrm{La}^{3+}$ $(0.116 \mathrm{~nm})$ and $\mathrm{Ce}^{3+}(0.114 \mathrm{~nm})$ generally yield $\mathrm{La}-$ and $\mathrm{Ce}-$ poor zirconolite relative to the other REE suite. A marked exception are zirconolites from xenoliths in the pyroclastic formations outcropping near Niedermendig, Laacher See eruptive center, Eifel volcanic region, Germany (Della Ventura et al., 2000) where zirconolite, baddeleyite, and monazite(La) crystallized in voids from late-stage La-enriched metasomatic fluids.

Figure 12a shows chondrite-normalized REE patterns for the Ardnamurchan and Glamaig samples. The patterns reflect the low $\mathrm{La}$ and $\mathrm{Ce}$ substitution at the M8 site. All three samples are enriched in HREEs (Tb-Lu REE), and, when measured, the distribution shows a moderate $\mathrm{Eu}$ anomaly $\left(\mathrm{Eu} / \mathrm{Eu}^{*}=0.34\right)$. Figure $12 \mathrm{~b}$ plots four other HREE-enriched zirconolites: one from St. Kilda, Scotland, and three typical lunar zirconolites. Zirconolite, usually accompanied by baddeleyite, is a common accessory mineral in evolved lunar rocks (e.g., Wark et al., 1973; Roedder and
Weiblen, 1978; Seddio et al., 2011; Norman and Nemchin, 2014). All the lunar examples come from late-stage mesostasis or residual liquids. The mesostasis composition typically varies from $\sim 4 \mathrm{wt} \%-10 \mathrm{wt} \%$ alkalis and $\sim 68 \mathrm{wt} \%-$ $78 \mathrm{wt} \% \mathrm{SiO}_{2}$ (Potts et al., 2016). The lunar zirconolites also show strong HREE enrichment, with a large Eu anomaly.

The granite zirconolite analyses have low totals, $93.4 \mathrm{wt} \%-94.3 \mathrm{wt} \%$. Although we did not analyze all the REEs or $\mathrm{Ta}-\mathrm{Ba}$ in some analyses - and the iron may be mostly ferric, it is probable that part of the deficit is due to the presence of water, as previously reported in zirconolite by Zakrzewski et al. (1992).

\subsection{Dalyite}

Dalyite, the rare potassium zirconium silicate with only 14 known occurrences (Mindat, 2020), was identified only in the Ailsa Craig riebeckite microgranite where it is abundant; there are more than 25 crystals in the thin section. It occurs as a late-stage phase filling voids and cracks, although some appear to have crystal faces (Fig. 13a, b). It ranges in size from $\leq 5-30 \mu \mathrm{m}$, but most are $\leq 10 \mu \mathrm{m}$. Their small size precluded an optimal EPMA procedure, and some $\mathrm{Na}$ loss was noted. A common association is the occurrence of fluornatropyrochlore, a pyrochlore-group mineral (Atencio et al., 2010) that precipitated coevally with the dalyite (Fig. 13c, d). No other Zr-bearing phase is associated with dalyite formation, at least texturally. Dalyite is cathodoluminescent in blue, with very minor or no zoning.

The empirical formula of dalyite is $\mathrm{K}_{2} \mathrm{ZrSi}_{6} \mathrm{O}_{15}$ (Back, 2018), but it can show limited substitutions. Jeffery et al. (2016) have summarized the possible site substitutions from a wide variety of lithological occurrences. The major exchange is $\mathrm{Na} \leftrightarrow \mathrm{K}$, with limited substitution in the tetrahedral and octahedral sites. The Ailsa Craig dalyite has mi- 

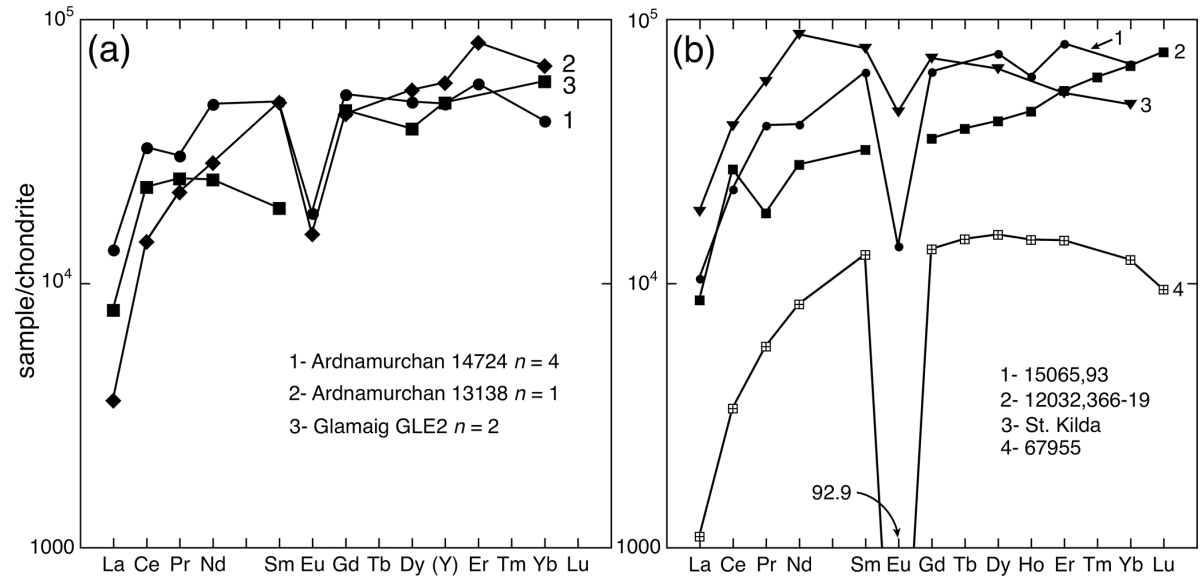

Figure 12. (a) Chondrite-normalized plot of zirconolite from Ardnamurchan (samples 14724, 13138) and Glamaig (sample GLE2). Yttrium plotted for Ho. (b) Chondrite-normalized plot of zirconolite from 15065,93 Apollo 15 basalt (Wark et al., 1973), 12032,366-19 Apollo 12 granite (Seddio et al., 2011), St. Kilda pegmatite (Fowler and Williams, 1986), and 67955 Apollo 16 melt rock (Norman and Nemchin, 2014). The normalized Eu value for 67955 is given but not plotted. Normalizing factors from McDonough and Sun (1995).
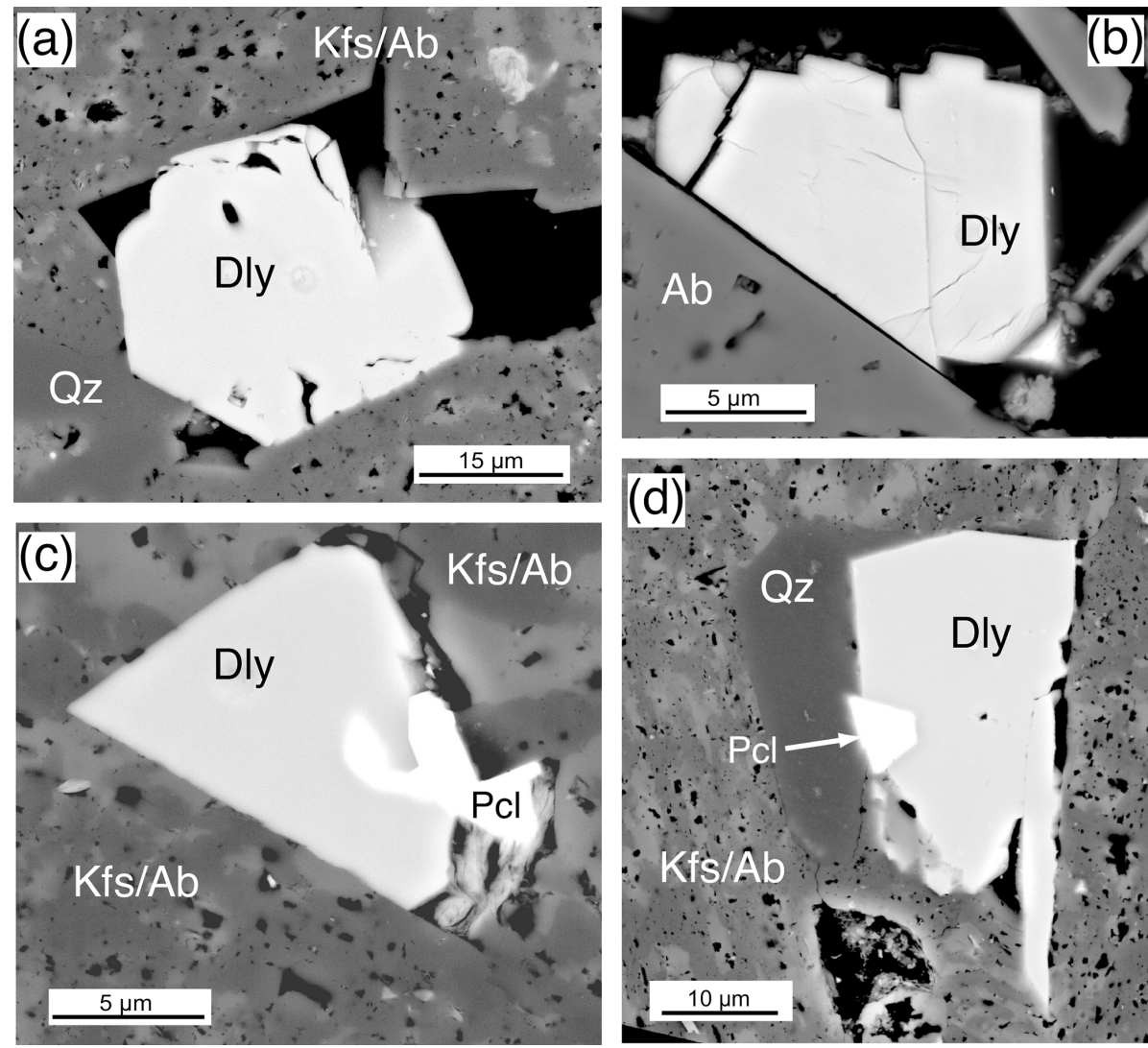

Figure 13. Dalyite, BSE images from sample DV24828, Ailsa Craig microgranite. (a) A $25 \mu \mathrm{m}$ dalyite (Dly) crystal precipitated in an open space formed by quartz (Qz) and inclusion-rich K-feldspar-albite (Kfs/Ab). (b) A euhedral, partially fractured, $15 \mu \mathrm{m}$ dalyite (Dly) that grew on albite $(\mathrm{Ab})$ in open space. (c) A $15 \mu \mathrm{m}$ dalyite (Dly) that filled an open space coeval with fluornatropyrochlore (Pcl). (d) A $15 \mu \mathrm{m}$ dalyite (Dly) filling an open space in K-feldspar and albite (Kfs/Ab) coeval with quartz (Qz) and fluornatropyrochlore (Pcl). 


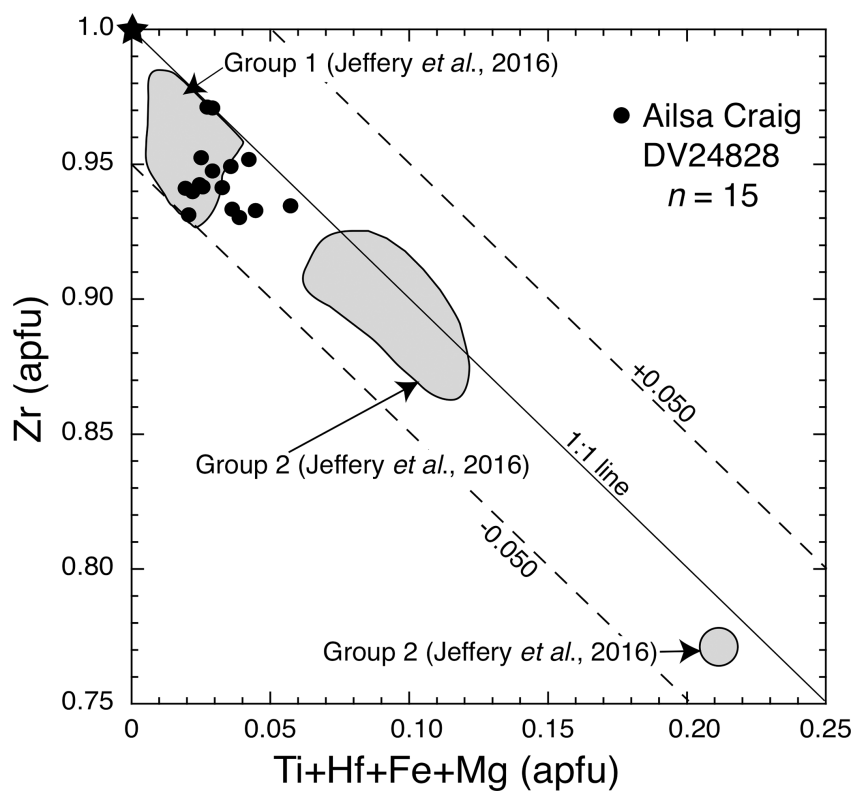

Figure 14. Variation diagram of $\mathrm{Zr}$ versus $(\mathrm{Ti}+\mathrm{Hf}+\mathrm{Fe}+\mathrm{Mg})$ apfu, showing substitution in the octahedral site in dalyite from sample DV24828, EPMA data, adapted from Jeffery et al. (2016). Also shown is the ideal dalyite composition (star) and dalyite compositional Group 1 (Terceira, Straumsvola, Ascension, Strange Lake) and Group 2 (Sunnfjord, Cancarix, Murun) from Jeffery et al. (2016).

nor substitution in both the $\mathrm{K} / \mathrm{Na}$ polyhedra and the octahedral site $((\mathrm{Ti}+\mathrm{Hf}+\mathrm{Fe}+\mathrm{Mn}+\mathrm{Al}) \leftrightarrow \mathrm{Zr})($ Table 12). Figure 14 shows the octahedral site substitution and a comparison with other dalyite occurrences. All data plot within 0.05 apfu of the one-to-one line, indicating a one-to-one cation exchange in the site, although, with the low degree of substitution, there is only a minor davanite $\left(\mathrm{K}_{2} \mathrm{TiSi}_{6} \mathrm{O}_{15}\right)$ component. The $\mathrm{K} / \mathrm{Na}$ site has a greater degree of substitution, with $\mathrm{K}+\mathrm{Na}+\mathrm{Ba}$ from 1.79-1.96 apfu. The lower values are the probable result of $\mathrm{Na}$ loss, with a concomitant increase in $\mathrm{Si}$. The range of apfu is as follows: $\mathrm{K} 1.71-1.88$, Na 0.028 0.200 , Ti 0.004-0.033, Hf 0.009-0.017, Al 0.003-0.101, and Fe 0.002-0.015; Mn (0.001-0.002 apfu) was detected in only $20 \%$ of the experiments, and $\mathrm{Mg}$ was below detection. Barium, $\mathrm{Ca}$, and $\mathrm{P}$ contents were minor or below detection. The dalyite analyses in the Ailsa Craig sample yield the average formula $\left(\mathrm{K}_{1.78} \mathrm{Na}_{0.13}\right)_{\Sigma 1.91}\left(\mathrm{Zr}_{0.94} \mathrm{Ti}_{0.011} \mathrm{Hf}_{0.013} \mathrm{Fe}_{0.008}\right.$ $\left.\mathrm{Al}_{0.019}\right)_{\Sigma 0.991} \mathrm{Si}_{6.04} \mathrm{O}_{15}$.

The Ailsa Craig dalyite composition is similar to those in Group 1 of Jeffery et al. (2016) - low octahedral (Fig. 14) but greater $\mathrm{K} \leftrightarrow \mathrm{Na}$ site substitution (Table 12) - which includes Terceira Island, Azores (Jeffery et al., 2016), Straumsvola Complex, Antarctica (Harris and Rickard, 1987), Strange Lake Complex, Canada (Birkett et al., 1992; Salvi and Williams-Jones, 1995), and the type locality, Ascension Island, South Atlantic Ocean (Van Tassel and Hey, 1952). Dalyite from these rocks reflects their low $\mathrm{TiO}_{2}$ content and sodic character. The Ailsa Craig microgranite has low $\mathrm{TiO}_{2}(0.11 \mathrm{wt} \%)$ and is sodic $(\mathrm{Na} / \mathrm{K} 2.2 \mathrm{~mol}$.) (Govindaraju, 1987; Table 2).

\subsection{Eudialyte-group minerals}

Eudialyte-group minerals (EGMs) are present in many forms in the Ailsa Craig microgranite, where it is abundant; there are more than 50 crystals in the thin section. EGMs are late phase and fill cracks and voids (Fig. 15a, b). They range in size up to $45 \mu \mathrm{m}$, but most are $\leq 15 \mu \mathrm{m}$. A euhedral crystal with two bladed offshoots and a partially rounded fluorite are enclosed in K-feldspar and albite (Fig. 15a). An aggregate of anhedral crystals is intergrown with quartz and feldspar in Fig. 15b with an intergrown britholite grain (Bri). The platy crystal in Fig. 15d has a dark core with a high $\mathrm{Z}$ mantle, and the prismatic crystal in Fig. 15e shows what may be sector zoning. A common association with EGMs is Zr-bearing aegirine and quartz (Fig. 15a, b, c, d). No intergrowths of dalyite, EGMs, or hydrothermal type 2 zircon were observed, although they are all late-stage phases. Zoning was observed in a few EGM crystals where a brighter BSE zone texturally follows a darker BSE zone separated by a sharp boundary (Fig. 15d, e).

Eudialyte-group minerals are a complex group of trigonal cyclosilicates with both three-fold $\left(\mathrm{Si}_{3} \mathrm{O}_{9}\right)_{6}$ and ninefold $\left(\mathrm{Si}_{9} \mathrm{O}_{27}\right)_{18}$ rings. A zeolite-like heteropolyhedral framework allows a considerable variety of elemental substitutions in different structural sites yielding a mineral group of structural complexity and chemical variability, with variable amounts of K, Sr, Fe, Mn, REEs, Y, Nb, Ti, and other elements (Johnsen and Gault, 1997; Johnsen and Grice, 1999; Johnsen et al., 2003; Bulakh and Petrov, 2004; Chukanov et al., 2004; Rastsvetaeva, 2007; Schilling et al., 2011; Rastsvetaeva et al., 2012; Borst et al., 2020). Chukanov et al. (2018) note that there are 28 members of the eudialyte group. The formula accepted by the International Mineralogical Association (IMA; Johnsen et al., 2003) for the group is $\left.N_{15-16}[M 1]_{6}[M 2]_{3}[M 3][M 4] Z_{3} \mathrm{Si}_{24} \mathrm{O}_{66-72}\right](\Theta)_{0-9} X_{2}$, where $N=\mathrm{Na}^{+}, \mathrm{Ca}^{2+}, \mathrm{K}^{+}, \mathrm{Sr}^{2+}, \mathrm{REE}^{3+}, \mathrm{Y}^{3+}, \square$ (vacancy), $\mathrm{Ba}^{2+}, \mathrm{Mn}^{2+}$, or $\mathrm{H}_{3} \mathrm{O}^{+} ; M 1=\mathrm{Ca}^{2+}, \mathrm{Mn}^{2+}, \mathrm{REE}^{3+}$, $\mathrm{Y}^{3+}, \mathrm{Na}^{+}, \mathrm{Sr}^{2+}$, or $\mathrm{Fe}^{2+} ; \mathrm{M}_{2}=\mathrm{Fe}^{2+}, \mathrm{Mn}^{2+}, \mathrm{Na}^{+}, \mathrm{Zr}^{4+}$, $\mathrm{Ta}^{5+}, \mathrm{Ti}^{4+}, \mathrm{K}^{+}, \mathrm{Ba}^{2+}, \square, \mathrm{H}_{3} \mathrm{O}^{+}$, or $\mathrm{Fe}^{3+} ; M 3 / 4=\mathrm{Si}^{4+}$, $\mathrm{Al}^{3+}, \mathrm{Nb}^{5+}, \mathrm{Ti}^{4+}, \mathrm{W}^{6+}$, or $\mathrm{Na}^{+} ; Z=\mathrm{Zr}^{4+}, \mathrm{Hf}^{4+}, \mathrm{Ti}^{4+}$, or $\mathrm{Nb}^{5+} ; \Theta=\mathrm{O}^{2-}, \mathrm{OH}^{-}, \mathrm{H}_{2} \mathrm{O}, \mathrm{CO}_{3}^{2-}, \mathrm{SO}_{4}^{2-}$, or $\mathrm{SiO}_{4}^{4-}$; and $X=\mathrm{Cl}^{-}, \mathrm{F}^{-}$, or $\mathrm{OH}^{-}$. Because of the site occupation complexity, the possible presence of different iron valences, vacancies, and hydrous species, the calculation of balanced mineral formulae is problematic, and this is especially true for EPMA data. The normalization scheme suggested by Johnsen and Grice (1999) is used here, in which the sum of $(\mathrm{Si}+\mathrm{Zr}+\mathrm{Ti}+\mathrm{Nb}+\mathrm{Al}+\mathrm{Hf}+\mathrm{Ta})$ cations was normalized to 29 cations per formula unit, and all other cation values result from this normalization (Table 13). 
Table 11. Compositions of zirconolite.

\begin{tabular}{|c|c|c|c|c|c|c|c|}
\hline \multirow{5}{*}{$\begin{array}{l}\text { Intrusion } \\
\text { Analysis } \\
N=\end{array}$} & \multirow{2}{*}{\multicolumn{5}{|c|}{ Ardnamurchan }} & \multirow{2}{*}{\multicolumn{2}{|c|}{$\begin{array}{c}\text { Skye } \\
\text { East. Red Hills Centre }\end{array}$}} \\
\hline & & & & & & & \\
\hline & \multirow{2}{*}{$\begin{array}{l}\text { Grig. Grano. } \\
\text { 13138_ZLa }\end{array}$} & \multicolumn{4}{|c|}{ Granophyre, Centre 2} & \multicolumn{2}{|c|}{ Glamaig Granite } \\
\hline & & 14724-ZL2 & 14724-ZL3 & 14724-ZL4 & 14724-ZL2b & GLE2a & GLE2b \\
\hline & 1 & 1 & 2 & 1 & 1 & 1 & 1 \\
\hline $\mathrm{SiO}_{2}($ wt $\%)$ & 1.98 & 0.60 & 1.37 & 0.44 & 2.38 & 0.10 & 0.08 \\
\hline $\mathrm{TiO}_{2}$ & 26.78 & 27.34 & 23.14 & 23.40 & 26.58 & 23.07 & 21.43 \\
\hline $\mathrm{Al}_{2} \mathrm{O}_{3}$ & 0.14 & 0.24 & 0.63 & 0.12 & 0.11 & 0.18 & 0.16 \\
\hline $\mathrm{FeO}^{*}$ & 10.82 & 10.52 & 8.58 & 10.17 & 9.67 & 9.77 & 10.04 \\
\hline $\mathrm{MnO}$ & na & na & na & na & na & 0.22 & 0.21 \\
\hline $\mathrm{MgO}$ & 0.24 & bdl & bdl & bdl & bdl & bdl & bdl \\
\hline $\mathrm{CaO}$ & 3.19 & 2.90 & 5.34 & 4.20 & 3.47 & 3.92 & 4.12 \\
\hline $\mathrm{BaO}$ & na & na & na & na & na & 0.09 & 0.10 \\
\hline $\mathrm{PbO}$ & 0.19 & bdl & 0.10 & bdl & bdl & na & na \\
\hline $\mathrm{ZrO}_{2}$ & 23.22 & 27.56 & 27.98 & 27.44 & 27.95 & 28.35 & 27.33 \\
\hline $\mathrm{HfO}_{2}$ & 0.79 & 0.95 & 1.19 & 0.90 & 0.84 & na & na \\
\hline $\mathrm{ThO}_{2}$ & 1.61 & 0.79 & 1.13 & 1.58 & 0.99 & 3.63 & 3.70 \\
\hline $\mathrm{UO}_{2}{ }^{2}$ & 0.99 & 0.33 & 0.58 & 0.78 & 0.30 & 2.18 & 2.55 \\
\hline $\mathrm{Nb}_{2} \mathrm{O}_{5}$ & 4.10 & 0.86 & 7.81 & 7.14 & 1.25 & 5.79 & 7.34 \\
\hline $\mathrm{Ta}_{2} \mathrm{O}_{5}$ & na & na & na & na & na & bdl & 0.12 \\
\hline $\mathrm{P}_{2} \mathrm{O}_{5}$ & 0.06 & 0.07 & 0.12 & 0.05 & 0.05 & bdl & bdl \\
\hline $\mathrm{Y}_{2} \mathrm{O}_{3}$ & 11.43 & 10.00 & 7.97 & 10.09 & 10.03 & 9.93 & 9.30 \\
\hline $\mathrm{La}_{2} \mathrm{O}_{3}$ & 0.10 & 0.12 & 0.46 & 0.45 & 0.46 & 0.17 & 0.27 \\
\hline $\mathrm{Ce}_{2} \mathrm{O}_{3}$ & 1.03 & 2.12 & 2.58 & 2.65 & 2.03 & 1.66 & 1.66 \\
\hline $\mathrm{Pr}_{2} \mathrm{O}_{3}$ & 0.24 & 0.40 & 0.40 & 0.11 & 0.41 & 0.27 & bdl \\
\hline $\mathrm{Nd}_{2} \mathrm{O}_{3}$ & 1.52 & 2.78 & 2.70 & 1.87 & 2.81 & 1.34 & 1.29 \\
\hline $\mathrm{Sm}_{2} \mathrm{O}_{3}$ & 0.83 & 0.81 & 0.96 & 0.50 & 1.07 & 0.34 & 0.32 \\
\hline $\mathrm{Eu}_{2} \mathrm{O}_{3}$ & 0.14 & bdl & bdl & 0.16 & 0.14 & bdl & bdl \\
\hline $\mathrm{Gd}_{2} \mathrm{O}_{3}$ & 1.00 & 1.56 & 0.97 & 1.12 & 1.11 & 0.96 & 1.11 \\
\hline $\mathrm{Tb}_{2} \mathrm{O}_{3}$ & na & na & na & na & na & bdl & bdl \\
\hline $\mathrm{Dy}_{2} \mathrm{O}_{3}$ & 1.52 & 1.49 & 1.29 & 0.85 & 1.86 & 1.00 & 1.17 \\
\hline $\mathrm{Ho}_{2} \mathrm{O}_{3}$ & na & na & na & na & na & 0.28 & bdl \\
\hline $\mathrm{Er}_{2} \mathrm{O}_{3}$ & 1.49 & 1.21 & 0.78 & 0.99 & 1.19 & na & na \\
\hline $\mathrm{Yb}_{2} \mathrm{O}_{3}$ & 1.22 & 0.76 & 0.69 & 1.01 & 0.56 & 1.03 & 1.10 \\
\hline Total & 94.64 & 93.41 & 96.76 & 96.03 & 95.27 & 94.28 & 93.40 \\
\hline$\Sigma \mathrm{REE}$ & 9.1 & 11.3 & 10.8 & 9.7 & 11.6 & 7.1 & 6.9 \\
\hline$\Sigma \mathrm{REE}+\mathrm{Y}$ & 20.5 & 21.3 & 18.8 & 19.8 & 21.7 & 17.0 & 16.2 \\
\hline \multicolumn{8}{|c|}{ Formulae on the basis of seven oxygens } \\
\hline $\mathrm{Si}$ & 0.139 & 0.043 & 0.095 & 0.031 & 0.166 & 0.007 & 0.006 \\
\hline $\mathrm{Ti}$ & 1.409 & 1.477 & 1.201 & 1.246 & 1.392 & 1.263 & 1.194 \\
\hline $\mathrm{Al}$ & 0.012 & 0.021 & 0.051 & 0.010 & 0.009 & 0.015 & 0.014 \\
\hline $\mathrm{Fe}^{2+}$ & 0.633 & 0.632 & 0.495 & 0.602 & 0.563 & 0.595 & 0.622 \\
\hline $\mathrm{Mn}$ & - & - & - & - & - & 0.014 & 0.013 \\
\hline $\mathrm{Mg}$ & 0.025 & - & 0.001 & - & - & - & - \\
\hline $\mathrm{Ca}$ & 0.239 & 0.223 & 0.394 & 0.319 & 0.259 & 0.306 & 0.327 \\
\hline $\mathrm{Ba}$ & - & - & - & - & - & 0.003 & 0.003 \\
\hline $\mathrm{Pb}$ & 0.004 & - & 0.002 & - & - & - & - \\
\hline $\mathrm{Zr}$ & 0.792 & 0.965 & 0.942 & 0.947 & 0.948 & 1.006 & 0.987 \\
\hline $\mathrm{Hf}$ & 0.016 & 0.020 & 0.023 & 0.018 & 0.017 & - & - \\
\hline Th & 0.026 & 0.013 & 0.018 & 0.025 & 0.016 & 0.060 & 0.062 \\
\hline $\mathrm{U}$ & 0.015 & 0.005 & 0.009 & 0.012 & 0.005 & 0.035 & 0.042 \\
\hline $\mathrm{Nb}$ & 0.130 & 0.028 & 0.244 & 0.229 & 0.039 & 0.191 & 0.246 \\
\hline $\mathrm{Ta}$ & - & - & - & - & - & - & 0.002 \\
\hline $\mathrm{P}$ & 0.004 & 0.004 & 0.007 & 0.003 & 0.003 & - & - \\
\hline $\mathrm{Y}$ & 0.425 & 0.382 & 0.292 & 0.380 & 0.371 & 0.384 & 0.366 \\
\hline $\mathrm{La}$ & 0.003 & 0.003 & 0.012 & 0.012 & 0.012 & 0.005 & 0.007 \\
\hline $\mathrm{Ce}$ & 0.026 & 0.056 & 0.065 & 0.069 & 0.052 & 0.044 & 0.045 \\
\hline $\operatorname{Pr}$ & 0.006 & 0.011 & 0.010 & 0.003 & 0.010 & 0.007 & - \\
\hline $\mathrm{Nd}$ & 0.038 & 0.071 & 0.066 & 0.047 & 0.070 & 0.035 & 0.034 \\
\hline $\mathrm{Sm}$ & 0.020 & 0.020 & 0.023 & 0.012 & 0.026 & 0.009 & 0.008 \\
\hline $\mathrm{Eu}$ & 0.003 & - & - & 0.004 & 0.003 & - & - \\
\hline Gd & 0.023 & 0.037 & 0.022 & 0.026 & 0.026 & 0.023 & 0.027 \\
\hline $\mathrm{Tb}$ & - & - & - & - & - & - & - \\
\hline Dy & 0.034 & 0.034 & 0.029 & 0.019 & 0.042 & 0.023 & 0.028 \\
\hline Ho & - & - & - & - & - & 0.006 & - \\
\hline $\mathrm{Er}$ & 0.033 & 0.027 & 0.017 & 0.022 & 0.026 & - & - \\
\hline $\mathrm{Yb}$ & 0.026 & 0.017 & 0.015 & 0.022 & 0.012 & 0.023 & 0.025 \\
\hline$\Sigma$ cations & 4.08 & 4.09 & 4.03 & 4.06 & 4.06 & 4.05 & 4.06 \\
\hline$\Sigma \mathrm{REE}$ & 0.213 & 0.276 & 0.258 & 0.236 & 0.277 & 0.175 & 0.175 \\
\hline$\Sigma \mathrm{REE}+\mathrm{Y}$ & 0.638 & 0.658 & 0.551 & 0.616 & 0.648 & 0.559 & 0.541 \\
\hline M8 & 0.92 & 0.90 & 0.97 & 0.97 & 0.93 & 0.96 & 0.97 \\
\hline
\end{tabular}

$+\mathrm{Ca}$ 
Table 12. Representative compositions of dalyite in Ailsa Craig granite DV24828.

\begin{tabular}{|c|c|c|c|c|c|c|c|c|}
\hline $\begin{array}{l}\text { Analysis } \\
N=\end{array}$ & $\begin{array}{r}\mathrm{D} 21.1-2 \\
2\end{array}$ & $\begin{array}{r}\text { D7.1 } \\
1\end{array}$ & $\begin{array}{r}\text { D20.1 } \\
1\end{array}$ & $\begin{array}{r}\text { D3.1 } \\
1\end{array}$ & $\begin{array}{r}\text { D17.1-2 } \\
2\end{array}$ & $\begin{array}{r}\mathrm{D} 23.1 \\
1\end{array}$ & $\begin{array}{r}\text { D14.1-2 } \\
2\end{array}$ & $\begin{array}{l}\text { Range } \\
n=15\end{array}$ \\
\hline $\mathrm{SiO}_{2}(\mathrm{wt} \%)$ & 63.24 & 64.19 & 63.54 & 63.03 & 62.95 & 63.12 & 63.37 & $62.95-63.89$ \\
\hline $\mathrm{TiO}_{2}$ & 0.27 & 0.25 & 0.34 & 0.06 & 0.46 & 0.06 & 0.07 & 0.05-0.46 \\
\hline $\mathrm{Al}_{2} \mathrm{O}_{3}$ & 0.04 & 0.06 & 0.05 & 0.70 & 0.04 & 0.50 & 0.05 & $0.03-0.90$ \\
\hline $\mathrm{FeO}^{*}$ & 0.06 & 0.09 & 0.07 & 0.10 & 0.14 & 0.11 & 0.07 & $0.02-0.19$ \\
\hline $\mathrm{MnO}$ & bdl & bdl & bdl & 0.02 & bdl & bdl & 0.02 & bdl-0.02 \\
\hline $\mathrm{MgO}$ & bdl & bdl & bdl & bdl & bdl & bdl & bdl & bdl \\
\hline $\mathrm{CaO}$ & bdl & 0.02 & bdl & bdl & bdl & 0.02 & bdl & bdl-0.02 \\
\hline $\mathrm{BaO}$ & bdl & 0.08 & 0.05 & bdl & 0.06 & bdl & bdl & bdl-0.08 \\
\hline $\mathrm{Na}_{2} \mathrm{O}$ & 0.79 & 0.41 & 0.82 & 0.59 & 0.58 & 0.59 & 0.95 & $0.15-1.09$ \\
\hline $\mathrm{K}_{2} \mathrm{O}$ & 14.40 & 14.26 & 14.06 & 15.13 & 14.26 & 14.67 & 14.64 & $14.06-15.52$ \\
\hline $\mathrm{ZrO}_{2}$ & 20.00 & 20.70 & 20.09 & 20.34 & 19.96 & 20.25 & 20.52 & 19.96-20.93 \\
\hline $\mathrm{HfO}_{2}$ & 0.45 & 0.64 & 0.53 & 0.40 & 0.46 & 0.47 & 0.49 & $0.35-0.64$ \\
\hline $\mathrm{P}_{2} \mathrm{O}_{5}$ & bdl & bdl & bdl & bdl & bdl & bdl & bdl & bdl-0.04 \\
\hline Total & 99.24 & 100.26 & 99.55 & 100.37 & 98.91 & 99.78 & 100.16 & 98.91-100.59 \\
\hline \multicolumn{9}{|c|}{ Formulae on the basis of 15 oxygens } \\
\hline $\mathrm{Si}$ & 6.053 & 6.046 & 6.055 & 5.993 & 6.046 & 6.020 & 6.034 & $5.990-6.055$ \\
\hline $\mathrm{Ti}$ & 0.019 & 0.018 & 0.024 & 0.004 & 0.033 & 0.004 & 0.005 & $0.004-0.033$ \\
\hline $\mathrm{Al}$ & 0.005 & 0.007 & 0.005 & 0.078 & 0.004 & 0.056 & 0.005 & $0.004-0.101$ \\
\hline $\mathrm{Fe}^{2+}$ & 0.005 & 0.007 & 0.005 & 0.008 & 0.011 & 0.009 & 0.005 & $0.002-0.015$ \\
\hline $\mathrm{Mn}$ & - & - & 0.001 & 0.001 & - & - & 0.002 & --0.002 \\
\hline $\mathrm{Mg}$ & - & - & - & - & - & - & - & - \\
\hline $\mathrm{Ca}$ & - & 0.002 & - & - & - & 0.002 & - & --0.002 \\
\hline $\mathrm{Ba}$ & - & 0.003 & 0.002 & - & 0.002 & - & - & --0.003 \\
\hline $\mathrm{Na}$ & 0.146 & 0.076 & 0.151 & 0.109 & 0.107 & 0.108 & 0.175 & $0.028-0.200$ \\
\hline $\mathrm{K}$ & 1.758 & 1.725 & 1.709 & 1.835 & 1.747 & 1.785 & 1.777 & $1.709-1.884$ \\
\hline $\mathrm{Zr}$ & 0.933 & 0.957 & 0.933 & 0.943 & 0.935 & 0.942 & 0.953 & $0.930-0.971$ \\
\hline $\mathrm{Hf}$ & 0.012 & 0.017 & 0.015 & 0.011 & 0.013 & 0.013 & 0.013 & $0.009-0.017$ \\
\hline $\mathrm{P}$ & - & - & - & - & - & - & - & --0.003 \\
\hline$\Sigma$ cations & 8.93 & 8.86 & 8.90 & 8.98 & 8.90 & 8.94 & 8.97 & $8.86-8.98$ \\
\hline$\Sigma(\mathrm{K}+\mathrm{Na}+\mathrm{Ba})$ & 1.90 & 1.80 & 1.86 & 1.94 & 1.86 & 1.89 & 1.95 & $1.80-1.96$ \\
\hline$\Sigma(\mathrm{Zr}+\mathrm{Hf}+\mathrm{Ti}+\mathrm{Fe}+\mathrm{Mn})$ & 0.97 & 1.00 & 0.98 & 0.97 & 0.99 & 0.97 & 0.98 & $0.95-1.00$ \\
\hline
\end{tabular}

$\mathrm{FeO}^{*}=$ total iron as $\mathrm{Fe}^{2+} ;$ bdl $=$ below detection limit; $N=$ number of analyses averaged

Electron beam analysis was challenging because in most cases, a recommended $20 \times 20 \mu \mathrm{m}$ defocused beam could not be used (Atanasova et al., 2015). The EGM in sample DV24828 was beam sensitive; $\mathrm{Na}$ and $\mathrm{Cl}$ were analyzed first, but $\mathrm{Na}$ loss and/or dehydration cannot be precluded. However, a comparison of the major element ranges (Table 13), $\mathrm{Fe}, \mathrm{Mn}, \mathrm{Na}, \mathrm{Ca}, \mathrm{Sr}, \mathrm{Si}, \mathrm{Nb}, \mathrm{Ti}, \mathrm{Zr}$, and $\mathrm{Cl}$, with the element ranges from a variety of EGM localities (e.g., Schilling et al., 2011; Table 3) shows that the Ailsa Craig EGMs are well within typical compositional ranges, except for Ca. In typical EGMs there are six $\mathrm{Ca}$ atoms per chemical formula, and these atoms are involved in a six-membered octahedral ring (e.g., Johnsen and Grice, 1999). The typical CaO content of IMA-accepted EGM species varies from $7 \mathrm{wt} \%-12 \mathrm{wt} \%$ (e.g., Bulakh and Petrov, 2004; Schilling et al., 2011). In oneillite, however, there are only three $\mathrm{Ca}$ atoms per formula unit (Johnsen et al., 1999), yielding a typical oneillite
$\mathrm{CaO}$ content of $2.90 \mathrm{wt} \%-3.13 \mathrm{wt} \%$. The $\mathrm{CaO}$ content of the Ailsa Craig EGM varies from $0.06 \mathrm{wt} \%-1.93 \mathrm{wt} \%$ (Table 13 ) with most $<0.50 \mathrm{wt} \%$ and only two grains $>1 \mathrm{wt} \%$ $\mathrm{CaO}$. This measurement yields apfu that vary from $0.03-1.03$ based on the recommended normalization. The EGM $M 1$ site is usually filled by $\mathrm{Ca}$ but can accommodate other cations as per the substitution $\mathrm{Ca} \leftrightarrow(\mathrm{Mn}, \mathrm{REEs}, \mathrm{Y}, \mathrm{Na}, \mathrm{Sr}, \mathrm{Fe}$ ).

We observed only a few zoned eudialyte grains, and only one was amenable to EPMA, although we obtained qualitative EDS data on others. The dark zone is richer in $\mathrm{Na}$ and $\mathrm{Zr}$ but poorer in $\Sigma$ REE, with the lighter zone having the opposite relative abundance (Table 13). Harris et al. (1982) describe similar zoning in late-stage eudialyte in a dalyitebearing granite.

Ailsa Craig EGM is highly enriched in $\mathrm{Y}$ and REEs with some of the highest weight percentage values reported; $\mathrm{Y}_{2} \mathrm{O}_{3}$ ranges from $2.62 \mathrm{wt} \%-5.04 \mathrm{wt} \%$, and $\Sigma$ REE ranges from 
Table 13. Representative compositions of probable eudialyte-group minerals in Ailsa Craig granite DV24828.

\begin{tabular}{|c|c|c|c|c|c|c|c|c|c|c|c|}
\hline $\begin{array}{l}\text { Analysis } \\
N=\end{array}$ & $\begin{array}{r}\text { E9.1-2 } \\
2\end{array}$ & $\begin{array}{r}\text { E17.1 } \\
1\end{array}$ & $\begin{array}{r}\text { E18.1 } \\
1\end{array}$ & $\begin{array}{r}\text { E21.1 } \\
1\end{array}$ & $\begin{array}{r}\text { E23.1 } \\
1\end{array}$ & $\begin{array}{r}\text { E26. } 1 \\
1\end{array}$ & $\begin{array}{r}\text { E32.1 } \\
1\end{array}$ & $\begin{array}{r}\text { E33.1 } \\
1\end{array}$ & $\begin{array}{l}\text { E14.1 } \\
\text { dark } 1\end{array}$ & $\begin{array}{l}\text { E14.2 } \\
\text { light } 1\end{array}$ & $\begin{array}{l}\text { Range } \\
n=21\end{array}$ \\
\hline $\mathrm{SiO}_{2}(\mathrm{wt} \%)$ & 50.38 & 50.60 & 50.35 & 47.79 & 49.79 & 49.49 & 50.69 & 49.25 & 52.01 & 52.77 & $47.79-52.77$ \\
\hline $\mathrm{TiO}_{2}$ & 0.40 & 0.42 & 0.30 & 0.68 & 0.66 & 0.38 & 0.50 & 0.55 & 0.28 & 0.38 & $0.28-0.68$ \\
\hline $\mathrm{Al}_{2} \mathrm{O}_{3}$ & bdl & bdl & bdl & bdl & bdl & bdl & bdl & bdl & 0.03 & 0.03 & bdl-0.03 \\
\hline $\mathrm{FeO}^{*}$ & 5.18 & 4.91 & 3.87 & 5.37 & 4.79 & 4.80 & 5.28 & 5.21 & 3.94 & 5.10 & $3.69-6.07$ \\
\hline $\mathrm{MnO}$ & 1.13 & 2.07 & 1.13 & 1.59 & 0.87 & 1.87 & 1.69 & 1.58 & 1.08 & 1.12 & $0.87-2.11$ \\
\hline $\mathrm{CaO}$ & 0.24 & 0.46 & 0.32 & 0.89 & 0.18 & 1.93 & 0.42 & 0.41 & 0.13 & 0.14 & $0.06-1.93$ \\
\hline $\mathrm{SrO}$ & 0.05 & 0.06 & bdl & bdl & bdl & bdl & 0.08 & 0.16 & bdl & 0.08 & bdl-0.16 \\
\hline $\mathrm{Na}_{2} \mathrm{O}$ & 13.88 & 11.77 & 13.35 & 14.15 & 14.06 & 11.32 & 13.38 & 14.11 & 13.83 & 11.74 & $10.53-14.66$ \\
\hline $\mathrm{K}_{2} \mathrm{O}$ & 0.48 & 0.40 & 0.47 & 0.39 & 0.40 & 0.37 & 0.34 & 0.36 & 0.16 & 0.28 & 016-0.55 \\
\hline $\mathrm{ZrO}_{2}$ & 14.69 & 11.24 & 13.17 & 12.54 & 15.29 & 9.15 & 12.22 & 12.22 & 16.04 & 12.88 & $9.15-16.17$ \\
\hline $\mathrm{HfO}_{2}$ & 0.12 & 0.25 & bdl & 0.19 & 0.22 & bdl & 0.24 & 0.38 & 0.15 & 0.34 & bdl- -0.43 \\
\hline $\mathrm{Nb}_{2} \mathrm{O}_{5}$ & 1.17 & 2.11 & 2.05 & 1.07 & 1.13 & 2.31 & 1.89 & 1.40 & 1.80 & 2.08 & $0.93-2.31$ \\
\hline $\mathrm{Ta}_{2} \mathrm{O}_{5}$ & 0.10 & bdl & 0.32 & 0.12 & bdl & 0.19 & 0.10 & bdl & bdl & bdl & bdl- -0.32 \\
\hline $\mathrm{P}_{2} \mathrm{O}_{5}$ & bdl & 0.07 & bdl & bdl & 0.07 & 0.07 & bdl & bdl & bdl & bdl & bdl-0.14 \\
\hline $\mathrm{Y}_{2} \mathrm{O}_{3}$ & 2.93 & 4.25 & 4.73 & 3.55 & 3.04 & 3.93 & 4.04 & 3.46 & 3.92 & 3.83 & $2.62-5.04$ \\
\hline $\mathrm{La}_{2} \mathrm{O}_{3}$ & 0.73 & 1.12 & 0.90 & 1.01 & 0.80 & 0.98 & 1.22 & 0.81 & 0.58 & 1.17 & $0.58-1.22$ \\
\hline $\mathrm{Ce}_{2} \mathrm{O}_{3}$ & 2.02 & 2.79 & 2.45 & 2.56 & 2.22 & 3.21 & 3.07 & 2.63 & 1.62 & 2.89 & $1.62-3.21$ \\
\hline $\mathrm{Pr}_{2} \mathrm{O}_{3}$ & 0.26 & 0.20 & 0.16 & 0.16 & 0.41 & 0.39 & 0.41 & 0.91 & bdl & 0.39 & bdl- -0.91 \\
\hline $\mathrm{Nd}_{2} \mathrm{O}_{3}$ & 1.03 & 1.86 & 1.34 & 1.83 & 1.02 & 2.15 & 1.60 & 1.39 & 1.08 & 1.37 & $0.60-2.15$ \\
\hline $\mathrm{Sm}_{2} \mathrm{O}_{3}$ & 0.12 & 0.64 & 0.53 & 0.44 & 0.22 & 0.42 & bdl & bdl & bdl & bdl & bdl- -0.68 \\
\hline $\mathrm{Gd}_{2} \mathrm{O}_{3}$ & 0.30 & 0.74 & 0.63 & 0.47 & 0.51 & 0.38 & 0.44 & 0.37 & 0.53 & 0.17 & bdl-0.94 \\
\hline $\mathrm{Dy}_{2} \mathrm{O}_{3}$ & 0.48 & 0.80 & 0.55 & 0.15 & 0.35 & 0.98 & 0.67 & 0.88 & 0.48 & 0.78 & $0.15-0.98$ \\
\hline $\mathrm{Er}_{2} \mathrm{O}_{3}$ & 0.47 & 0.54 & 0.43 & 0.69 & 0.35 & 0.31 & 0.27 & 0.36 & 0.51 & 0.47 & $0.18-0.69$ \\
\hline $\mathrm{Yb}_{2} \mathrm{O}_{3}$ & 0.23 & 0.45 & 0.48 & 0.25 & 0.13 & 0.39 & 0.33 & 0.10 & 0.14 & 0.21 & $0.10-0.53$ \\
\hline $\mathrm{Cl}$ & 1.95 & 1.99 & 2.02 & 2.00 & 2.11 & 2.07 & 1.93 & 1.97 & 2.02 & 2.19 & $1.92-2.19$ \\
\hline$-\mathrm{O} \equiv \mathrm{Cl}$ & 0.44 & 0.45 & 0.46 & 0.45 & 0.48 & 0.47 & 0.44 & 0.44 & 0.46 & 0.50 & \\
\hline Total & 97.89 & 99.29 & 99.08 & 97.44 & 98.12 & 96.60 & 100.36 & 98.07 & 99.87 & 99.91 & 95.9-100.4 \\
\hline$\Sigma$ REE & 5.57 & 9.14 & 7.46 & 7.55 & 6.00 & 9.19 & 8.00 & 7.46 & 4.94 & 7.44 & 4.94-9.19 \\
\hline$\Sigma \mathrm{REE}+\mathrm{Y}$ & 8.49 & 13.39 & 12.19 & 11.10 & 9.04 & 13.12 & 12.04 & 10.92 & 8.86 & 11.27 & $7.91-13.39$ \\
\hline \multicolumn{12}{|c|}{ Cations on the basis of $(\mathrm{Si}+\mathrm{Ti}+\mathrm{Al}+\mathrm{Zr}+\mathrm{Hf}+\mathrm{Nb}+\mathrm{Ta})=29$} \\
\hline $\mathrm{Si}$ & 25.001 & 25.557 & 25.171 & 25.204 & 24.761 & 25.939 & 25.355 & 25.339 & 24.754 & 25.332 & $24.67-25.94$ \\
\hline $\mathrm{Ti}$ & 0.151 & 0.158 & 0.111 & 0.269 & 0.247 & 0.148 & 0.188 & 0.214 & 0.099 & 0.137 & $0.10-0.27$ \\
\hline $\mathrm{Al}$ & - & - & - & - & - & - & - & - & 0.017 & 0.018 & --0.02 \\
\hline $\mathrm{Fe}$ & 2.150 & 2.074 & 1.618 & 2.368 & 1.992 & 2.104 & 2.209 & 2.242 & 1.568 & 2.047 & $1.55-2.58$ \\
\hline $\mathrm{Mn}$ & 0.475 & 0.886 & 0.480 & 0.710 & 0.365 & 0.830 & 0.716 & 0.689 & 0.435 & 0.454 & $0.36-0.94$ \\
\hline $\mathrm{Ca}$ & 0.125 & 0.251 & 0.173 & 0.505 & 0.096 & 1.084 & 0.222 & 0.225 & 0.067 & 0.070 & $0.03-1.08$ \\
\hline $\mathrm{Sr}$ & 0.013 & 0.018 & - & - & - & - & 0.022 & 0.049 & - & 0.023 & --0.05 \\
\hline $\mathrm{Na}$ & 13.356 & 11.526 & 12.940 & 14.469 & 13.558 & 11.504 & 12.977 & 14.076 & 12.763 & 10.927 & $10.37-14.47$ \\
\hline K & 0.305 & 0.258 & 0.297 & 0.260 & 0.251 & 0.247 & 0.214 & 0.236 & 0.100 & 0.168 & $0.10-0.35$ \\
\hline $\mathrm{Zr}$ & 3.555 & 2.768 & 3.211 & 3.225 & 3.708 & 2.339 & 2.981 & 3.066 & 3.723 & 3.015 & $2.34-3.86$ \\
\hline $\mathrm{Hf}$ & 0.017 & 0.035 & - & 0.028 & 0.031 & - & 0.035 & 0.055 & 0.020 & 0.047 & --0.06 \\
\hline $\mathrm{Nb}$ & 0.263 & 0.482 & 0.463 & 0.256 & 0.254 & 0.547 & 0.427 & 0.325 & 0.387 & 0.451 & $0.21-0.55$ \\
\hline Тa & 0.013 & - & 0.044 & 0.018 & - & 0.027 & 0.013 & - & - & - & --0.04 \\
\hline $\mathrm{P}$ & - & 0.030 & - & - & 0.029 & 0.029 & - & - & - & - & --0.06 \\
\hline Y & 0.772 & 1.141 & 1.257 & 0.995 & 0.804 & 1.095 & 1.074 & 0.946 & 0.992 & 0.977 & $0.68-1.35$ \\
\hline $\mathrm{La}$ & 0.133 & 0.208 & 0.166 & 0.196 & 0.147 & 0.189 & 0.225 & 0.154 & 0.102 & 0.207 & $0.10-0.23$ \\
\hline $\mathrm{Ce}$ & 0.366 & 0.515 & 0.448 & 0.494 & 0.404 & 0.615 & 0.562 & 0.495 & 0.282 & 0.507 & $0.28-0.62$ \\
\hline $\operatorname{Pr}$ & 0.047 & 0.038 & 0.029 & 0.031 & 0.075 & 0.074 & 0.075 & 0.171 & - & 0.068 & --0.17 \\
\hline $\mathrm{Nd}$ & 0.182 & 0.335 & 0.239 & 0.344 & 0.181 & 0.402 & 0.286 & 0.255 & 0.183 & 0.235 & $0.10-0.40$ \\
\hline $\mathrm{Sm}$ & 0.020 & 0.110 & 0.091 & 0.080 & 0.037 & 0.075 & - & - & - & - & --0.11 \\
\hline $\mathrm{Gd}$ & 0.050 & 0.124 & 0.103 & 0.081 & 0.083 & 0.066 & 0.073 & 0.063 & 0.083 & 0.026 & --0.15 \\
\hline Dy & 0.077 & 0.130 & 0.088 & 0.025 & 0.057 & 0.164 & 0.107 & 0.145 & 0.074 & 0.120 & $0.03-0.16$ \\
\hline $\mathrm{Er}$ & 0.073 & 0.086 & 0.068 & 0.114 & 0.054 & 0.051 & 0.042 & 0.059 & 0.076 & 0.071 & $0.03-0.11$ \\
\hline $\mathrm{Yb}$ & 0.035 & 0.070 & 0.072 & 0.041 & 0.019 & 0.061 & 0.050 & 0.016 & 0.021 & 0.030 & $0.02-0.08$ \\
\hline $\mathrm{Cl}$ & 1.640 & 1.704 & 1.708 & 1.787 & 1.781 & 1.841 & 1.639 & 1.715 & 1.626 & 1.786 & $1.56-1.86$ \\
\hline Total & 48.82 & 48.50 & 48.78 & 51.50 & 48.93 & 49.43 & 49.49 & 50.53 & 47.37 & 46.72 & $46.7-51.5$ \\
\hline$\Sigma$ REE & 0.98 & 1.62 & 1.31 & 1.41 & 1.06 & 1.70 & 1.42 & 1.36 & 0.32 & 1.27 & $0.82-1.70$ \\
\hline$\Sigma \mathrm{REE}+\mathrm{Y}$ & 1.75 & 2.76 & 2.56 & 2.41 & 1.86 & 2.79 & 2.49 & 2.30 & 1.81 & 2.24 & $1.59-2.83$ \\
\hline
\end{tabular}

$\mathrm{FeO}^{*}=$ total iron as $\mathrm{Fe}^{2+} ;$ bdl $=$ below detection limit; $N=$ number of analyses averaged. 

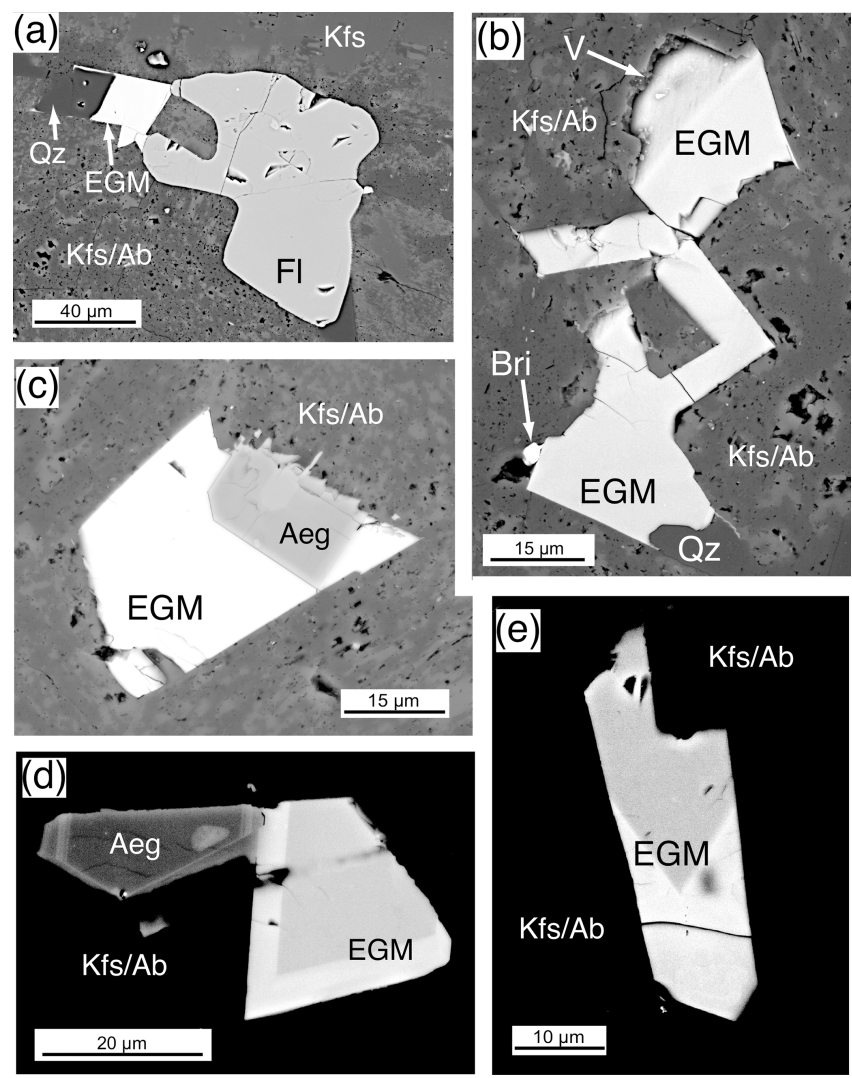

Figure 15. Eudialyte-group mineral (EGM), BSE images from sample DV24828 Ailsa Craig microgranite. (a) A $20 \mu \mathrm{m}$ EGM adjacent to fluorite $(\mathrm{Fl})$ that filled an open space with quartz (Qz) enclosed by $\mathrm{K}$-feldspar and albite (Kfs/Ab). (b) A $75 \mu \mathrm{m}$ group of EGM filling a large open space in K-feldspar and albite (Kfs/Ab). The EGM appears coeval with quartz $(\mathrm{Qz})$ and was followed by britholite (Bri). The sample preparation has exposed a vug (V). (c) A $22 \mu \mathrm{m}$ EGM that has grown over a euhedral Zr-bearing aegirine (Aeg) enclosed by K-feldspar and albite (Kfs/Ab). (d) A $23 \mu \mathrm{m}$ zoned EGM adjacent to a $\mathrm{Zr}$-bearing aegirine (Aeg) enclosed by $\mathrm{K}$-feldspar and albite (Kfs/Ab). The contrast in this image and in (e) has been adjusted to show the zoning. The bright rim has high REEs and lower $\mathrm{Na}_{2} \mathrm{O}$ than the darker portion. (e) A $45 \mu \mathrm{m}$ zoned EGM filling an open space enclosed by K-feldspar and albite (Kfs/Ab). The composition of the bright and dark portions is given in Table 13; the bright part has high REEs and lower $\mathrm{Na}_{2} \mathrm{O}$ than the darker portion.

$4.94 \mathrm{wt} \%-9.19 \mathrm{wt} \%$. These values yield $\Sigma \mathrm{REE}+\mathrm{Y}$ that vary from $7.91 \mathrm{wt} \%-13.13 \mathrm{wt} \%$, with Y dominant. Ailsa Craig microgranite EGMs, along with britholite-(Ce) (Macdonald et al., 2013b), monazite-(Ce), hydrothermal zircon, and a pyrochlore-group mineral, are the main REE carriers. Figure 16 shows the chondrite-normalized plot of the Ailsa Craig microgranite compared to EGMs. The microgranite is enriched slightly in LREEs with a flat HREE distribution, with $[\mathrm{La} / \mathrm{Yb}]_{\mathrm{CN}}$ in the range of 2.2-4.1. Although the REEs in EGM show variability, the overall patterns are similar to the bulk rock.

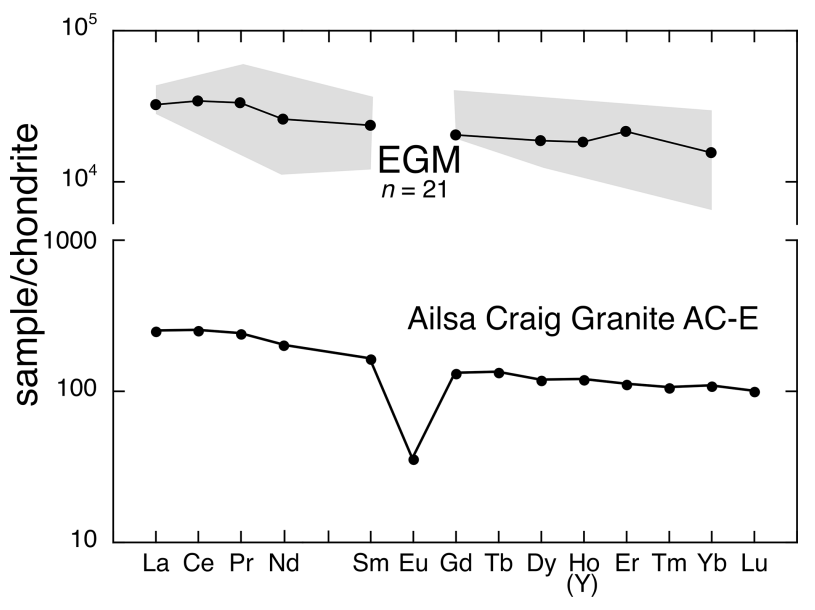

Figure 16. Chondrite-normalized plot comparing the REE pattern from Ailsa Craig granite AC-E (Govindaraju, 1987; Table 2) with measured range and average REEs from EGMs in this study (sample DV24828). Ho plotted in granite and Y plotted for Ho in EGMs. Normalizing factors from McDonough and Sun (1995).

EGMs are particularly prone to being partly to completely replaced by secondary phases during magmatic to hydrothermal stages (Mitchell and Liferovich, 2006; Sheard et al., 2012; Karup-Møller and Rose-Hansen, 2013; Wu et al., 2016; Estrade et al., 2014, 2018). In the Ailsa Craig microgranite, a positive correlation between analytical totals and $\mathrm{Na}_{2} \mathrm{O}$ contents may indicate the slight loss of $\mathrm{Na}$ during secondary hydration. Such hydration might also explain low EPMA totals; otherwise, the EGMs seem not to have suffered significant replacement.

\subsection{Zr-bearing fibrous mineral}

Sheaflike bundles of Zr-bearing fibers occur in cracks and crevices in earlier formed minerals in the Ailsa Craig microgranite (Fig. 17). Individual fibers are generally $<1 \mu \mathrm{m}$ thick and a few micrometers long. The mode of occurrence suggests late-stage formation, and the texture indicates that it is not an alteration phase of its adjacent hosts.

The fiber surface was poorly polished and/or the fiber bundles were slightly recessed, making EPMA experiments questionable. Furthermore, the intrinsically high EPMA probe current produced some damage. We used EDS to attempt to determine composition. Concentrations were calculated from the count data using the factory standardization and the PeBaZAF quantification scheme recommended for samples with rough surfaces. The EDAX PeBaZAF correction scheme does not normalize to $100 \%$; thus it is helpful in identifying hydrous phases. The mean fiber composition is $(N=4) \mathrm{SiO}_{2} 52.8, \mathrm{TiO}_{2} 0.4, \mathrm{Al}_{2} \mathrm{O}_{3} 5.3, \mathrm{FeO}^{\text {total }} 5.6, \mathrm{MnO}$ 0.8, $\mathrm{MgO} 0.4, \mathrm{CaO} 4.8, \mathrm{Na}_{2} \mathrm{O} 4.3, \mathrm{~K}_{2} \mathrm{O} 0.9, \mathrm{ZrO}_{2} 20.1, \mathrm{HfO}_{2}$ 2.4 , and total 97.8 (wt \%). All totals are low, suggesting a hydrous phase. 

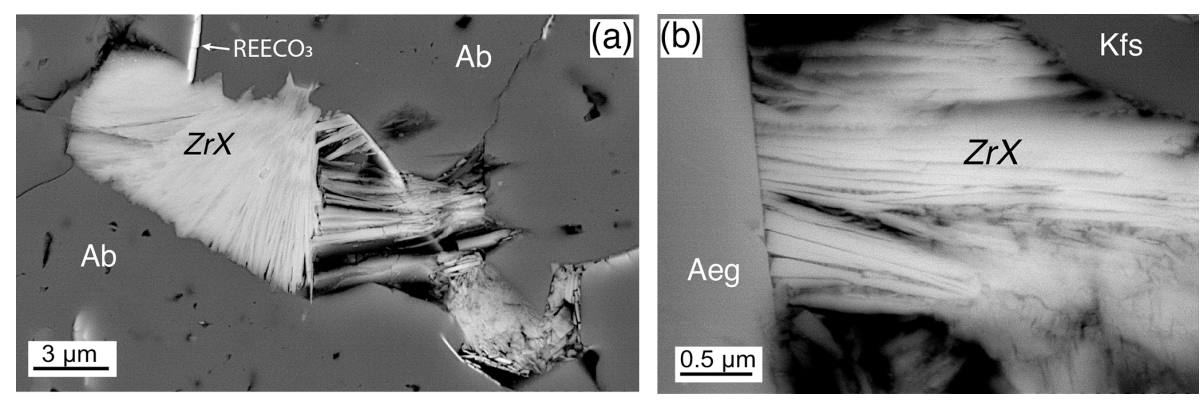

Figure 17. BSE images, Ailsa Craig microgranite, sample DV24828. (a) Typical texture of Zr-bearing fibrous phase ( $Z r X)$ in a vug in albite. (b) Zr-bearing fibers $(\mathrm{ZrX}), \sim 100-200 \mathrm{~nm}$ in width, in an open space between aegirine (Aeg) and K-feldspar (Kfs).

In the Ailsa Craig microgranite, Harding (1983) described fibrous glauconitic minerals of interstitial crystallization whose composition is typical for that mineral group with essentially nil $\mathrm{ZrO}_{2}$. Piilonen et al. (1998) described fibrous aegirine, whose composition is depleted of $\mathrm{ZrO}_{2}$ and $\mathrm{TiO}_{2}$ and enriched in the aegirine component, unlike the Ailsa Craig $\mathrm{Zr}$-bearing fibers. The literature description of the sheaflike habit of lemoynite $\left((\mathrm{Na}, \mathrm{K})_{2} \mathrm{CaZr}_{2} \mathrm{Si}_{10} \mathrm{O}_{26} 5-6 \mathrm{H}_{2} \mathrm{O}\right)$ (Perrault et al., 1969; Anthony et al., 1995) and other members of the lemoynite group (McDonald and Chao, 2001; McDonald et al., 2015) fits the morphology of the Ailsa Craig Zr-bearing fibers. Additionally, the $\mathrm{SiO}_{2}, \mathrm{ZrO}_{2}, \mathrm{CaO}$, and $\mathrm{Na}_{2} \mathrm{O}$ abundances of lemoynite are similar to those in the Ailsa Craig fibers. However, further work is needed to identify this $\mathrm{Zr}$ bearing fibrous silicate.

\subsection{Zr-bearing aegirine}

The Ailsa Craig microgranite has both late-stage Zr-bearing clinopyroxene and riebeckite-arfvedsonite. The $\mathrm{Zr}$ abundance in the amphibole is low, $0.62 \mathrm{wt} \% \mathrm{ZrO}_{2}$ (Harrison et al., 1987, their Table 2, mean of 48 analyses), and that concentration was confirmed with EDS. However, Harding (1983) reported that the clinopyroxene has up to 3.15 $\mathrm{ZrO}_{2} \mathrm{wt} \%$. Furthermore, the $\mathrm{Zr}$-bearing clinopyroxene is frequently associated with EGM precipitation (Fig. 15c, d); thus, a reconnaissance study of the clinopyroxene was made. Many clinopyroxene grains were in cracks or poorly polished, limiting the EPMA study.

In Ailsa Craig sample DV24828, the clinopyroxene occurs as euhedral, subhedral, and interstitial grains; although texturally related to EGM, it is not associated with dalyite, at least not in our sample. Harding (1983) and Harrison et al. (1987) report a range of aegirine-hedenbergite compositions in various parts of the Ailsa Craig microgranite. Our analyses yielded aegirine compositions (Table 14). The compositions have a limited range and are intermediate between the low and high $\mathrm{CaO}$ clinopyroxenes reported by Harding (1983) in the microgranite. The $T$ site shows almost complete occupancy by Si and varies from 1.98-1.99 apfu, and the $\mathrm{Al}$ content is very low. Low $\mathrm{Al}$ clinopyroxene, usually
Zr-bearing, has been described from peralkaline rocks such as fenite (Ranløv and Dymek, 1981), peralkaline nepheline syenite (Shearer and Larsen, 1994; Preston et al., 1998; Murad, 2006), K-Na agpaitic syenite (Arzamastsev et al., 2000), peralkaline trachyte and comendite (Duggan, 1988), and trachyphonolite (Melluso et al., 2012). The M2 site has limited $\mathrm{Na} \leftrightarrow \mathrm{Ca}$ substitution; Na varies from 0.91-0.96 apfu, and $\mathrm{Ca}$ varies from $0.10-0.13$ apfu. The $\mathrm{Fe}^{3+} / \mathrm{Fe}^{2+}$ ratio was adjusted to compensate for charge balance considerations related to $\mathrm{Na} \leftrightarrow \mathrm{Ca}$ substitution. $\mathrm{MgO}$ was consistently below detection; thus the aegirine composition varies between Ae and $\mathrm{Hd}$. The $\mathrm{ZrO}_{2}$ content varies from $2.2 \mathrm{wt} \%-3.1 \mathrm{wt} \%$, yielding apfu from 0.041-0.057. Jones and Peckett (1980) suggested that $\mathrm{Zr}$ is incorporated in the pyroxene structure only when no other Zr-bearing phase, such as eudialyte, is formed. In contrast, we find a common textural association between $\mathrm{Zr}$-aegirine and a $\mathrm{Zr}$-bearing EGM in the Ailsa Craig sample, indicating that they are both late-stage phases forming during the same time. The aegirine analyses showed scattered REE contents at or just above the detection limit (Table 14). A worthwhile study would be to analyze the Ailsa Craig $\mathrm{Zr}$-aegirine with LA-ICP-MS for a complete picture of the REE content.

\section{Discussion}

\subsection{Crystallization sequence}

Judging from the examples shown in the BSE images in Figs. 2, 7, 8, 9, and 10 the order of crystallization in the granites, excepting Ailsa Craig, was baddeleyite $\rightarrow$ zirconolite $\rightarrow$ zircon $\rightarrow$ hydrothermal zircon. Crystals of baddeleyite, zirconolite, and zircon are clearly magmatic; they are euhedral and enclosed in early-crystallizing phases, and some may show magmatic zoning. The late-magmatic zircons mainly fill spaces between crystals and vugs, although there is still some magmatic zoning. In the Ailsa Craig granite, all Zr-bearing phases, dalyite, EGM, zircon, $\mathrm{Zr}$-aegirine, and probable lemoynite are late-stage with no obvious textures that would suggest a definitive sequence. Hydrothermal 
Table 14. Compositions of $\mathrm{Zr}$-bearing aegirine.

\begin{tabular}{|c|c|c|c|c|}
\hline \multirow{3}{*}{$\begin{array}{l}\text { Analysis } \\
N=\end{array}$} & \multicolumn{4}{|c|}{ Ailsa Craig granite } \\
\hline & E7.2 & E12.1 & E12.2 & E13.1 \\
\hline & 1 & 1 & 1 & 1 \\
\hline $\mathrm{SiO}_{2}(\mathrm{wt} \%)$ & 52.06 & 52.22 & 51.83 & 52.31 \\
\hline $\mathrm{TiO}_{2}$ & 1.51 & 1.68 & 0.84 & 0.87 \\
\hline $\mathrm{Al}_{2} \mathrm{O}_{3}$ & 0.21 & 0.26 & 0.20 & 0.19 \\
\hline $\mathrm{Fe}_{2} \mathrm{O}_{3} *$ & 28.13 & 28.16 & 28.55 & 28.83 \\
\hline $\mathrm{MnO}$ & 0.49 & 0.50 & 0.39 & 0.38 \\
\hline $\mathrm{MgO}$ & bdl & bdl & bdl & bdl \\
\hline $\mathrm{CaO}$ & 3.14 & 2.68 & 2.49 & 2.56 \\
\hline $\mathrm{SrO}$ & bdl & bdl & bdl & 0.07 \\
\hline $\mathrm{Na}_{2} \mathrm{O}$ & 12.26 & 13.09 & 12.80 & 12.76 \\
\hline $\mathrm{K}_{2} \mathrm{O}$ & 0.02 & bdl & bdl & bdl \\
\hline $\mathrm{ZrO}_{2}$ & 2.19 & 2.50 & 2.66 & 3.07 \\
\hline $\mathrm{HfO}_{2}$ & 0.20 & 0.21 & 0.16 & 0.29 \\
\hline $\mathrm{Nb}_{2} \mathrm{O}_{5}$ & 0.22 & 0.27 & bdl & bdl \\
\hline $\mathrm{Y}_{2} \mathrm{O}_{3}$ & 0.12 & bdl & bdl & bdl \\
\hline $\mathrm{La}_{2} \mathrm{O}_{3}$ & bdl & bdl & bdl & 0.10 \\
\hline $\mathrm{Pr}_{2} \mathrm{O}_{3}$ & bdl & bdl & 0.14 & bdl \\
\hline $\mathrm{Nd}_{2} \mathrm{O}_{3}$ & 0.23 & bdl & bdl & 0.31 \\
\hline $\mathrm{Sm}_{2} \mathrm{O}_{3}$ & bdl & 0.16 & bdl & bdl \\
\hline $\mathrm{Gd}_{2} \mathrm{O}_{3}$ & bdl & bdl & 0.24 & bdl \\
\hline $\mathrm{Yb}_{2} \mathrm{O}_{3}$ & bdl & bdl & bdl & 0.14 \\
\hline Total & 100.78 & 101.73 & 100.30 & 101.89 \\
\hline \multicolumn{5}{|c|}{ Formulae on the basis of six oxygens and four cations } \\
\hline $\mathrm{Si}$ & 1.991 & 1.981 & 1.996 & 1.990 \\
\hline $\mathrm{Ti}$ & 0.044 & 0.048 & 0.024 & 0.025 \\
\hline $\mathrm{Al}$ & 0.009 & 0.011 & 0.009 & 0.009 \\
\hline $\mathrm{Fe}^{3+}$ & 0.732 & 0.721 & 0.756 & 0.762 \\
\hline $\mathrm{Fe}^{2+}$ & 0.113 & 0.093 & 0.090 & 0.092 \\
\hline $\mathrm{Mn}$ & 0.016 & 0.016 & 0.013 & 0.012 \\
\hline $\mathrm{Mg}$ & - & - & - & - \\
\hline $\mathrm{Ca}$ & 0.129 & 0.109 & 0.103 & 0.104 \\
\hline $\mathrm{Sr}$ & - & - & - & 0.002 \\
\hline $\mathrm{Na}$ & 0.909 & 0.963 & 0.956 & 0.941 \\
\hline $\mathrm{K}$ & 0.001 & - & - & - \\
\hline $\mathrm{Zr}$ & 0.041 & 0.046 & 0.050 & 0.057 \\
\hline Hf & 0.002 & 0.002 & 0.002 & 0.003 \\
\hline $\mathrm{Nb}$ & 0.004 & 0.005 & - & - \\
\hline $\mathrm{Y}$ & 0.002 & - & - & - \\
\hline $\mathrm{La}$ & - & - & - & 0.001 \\
\hline $\operatorname{Pr}$ & - & - & 0.002 & - \\
\hline $\mathrm{Nd}$ & 0.003 & - & - & 0.004 \\
\hline $\mathrm{Sm}$ & - & 0.002 & - & - \\
\hline Gd & - & - & 0.003 & - \\
\hline $\mathrm{Yb}$ & - & - & 0.000 & 0.002 \\
\hline$\Sigma$ cations & 4.00 & 4.00 & 4.00 & 4.00 \\
\hline$\% \mathrm{Ae}^{* *}$ & 87 & 89 & 89 & 89 \\
\hline
\end{tabular}

$\mathrm{Fe}_{2} \mathrm{O}_{3}^{*}=$ all $\mathrm{Fe}$ as $\mathrm{Fe}^{3+} ;$ bdl $=$ below detection limit. $\mathrm{Fe}^{3+} / \mathrm{Fe}^{2+}$ based on stoichiometry. $N=$ number of analyses averaged. $\mathrm{Ta}_{2} \mathrm{O}_{5}, \mathrm{Ce}_{2} \mathrm{O}_{3}$, $\mathrm{Dy}_{2} \mathrm{O}_{3}, \mathrm{Er}_{2} \mathrm{O}_{3}=$ bdl. $* *$ method of Morimoto (1989). zircon is present in several forms, and a major feature is the high concentration of incompatible elements and the abundance of inclusions. We observed no texture that suggested that early formed magmatic zircon was altered by late-stage solutions to yield either hydrothermal type 1 or type 2 .

\subsection{Mineral parageneses}

Zirconolite and baddeleyite occur in a wide range of terrestrial rocks, including carbonatites, kimberlites, mafic and ultramafic intrusions, dolerite dikes, alkaline intrusions, pegmatites, potassic lavas, skarns, metacarbonates, and granulites. The textural relationships between them and with zircon are highly variable. Barkov et al. (1995) found zircon replacing baddeleyite in the Imandrovsky mafic intrusion, Kola Peninsula, Russia. Baddeleyite and zirconolite have been reported as coexisting, although not necessarily in equilibrium, in, inter alia, intercumulus areas in the Rhum (Rum) layered intrusion, Scotland (Williams, 1978). Williams (1996) showed that zirconolite crystallized later than, and sometimes replaced, baddeleyite in phoscorite of the Kovdor carbonatite complex, Kola Peninsula, Russia. In potassic rocks of the Lewotolo volcano, Indonesia, the three phases apparently crystallized in the sequence zircon $\rightarrow$ zirconolite $\rightarrow$ baddeleyite (de Hoog and van Bergen, 2000). Most sills and dikes emplaced during the Franklin episode in northern Canada contain zircon, baddeleyite, and zirconolite; some zirconolite grains apparently precipitated with, or later than, baddeleyite (Heaman et al., 1992). In carbonatite veins of the Jacupiranga complex, southern Brazil, baddeleyite occurs as tabular crystals containing zirconolite (Salvioli-Mariani et al., 2012). Zhao et al. (2016) reported baddeleyite and zircon precipitated from hydrothermal fluids during skarnization at the Tengtie iron deposit, South China.

In the UK granites of this study, baddeleyite and zirconolite crystallized in the type 1 (biotite \pm amphibole) and type 2 (hedenbergite-fayalitic olivine) granites, and the order of crystallization, as noted above, was baddeleyite $\rightarrow$ zirconolite $\rightarrow$ zircon. The textural relationships of the zirconolite (also baddeleyite) in the Ardnamurchan samples are similar to those described for St. Kilda and lunar zirconolite, i.e., precipitation from late-stage liquids in which HREE concentration is high and silica activity is low enough to form $\mathrm{Zr}$ oxides and not zircon.

Various factors have been invoked to explain the stability relationships of the three phases:

i. Silica activity. In reversible, anhydrous, relatively hightemperature experiments, the equilibrium reaction is $\mathrm{ZrO}_{2}+\mathrm{SiO}_{2} \leftrightarrow \mathrm{ZrSiO}_{4}$. Yet, in both the Rum and Ardnamurchan samples, baddeleyite is commonly hosted by quartz (e.g., Fig. 10a), and at high magnification using FE-SEM, no incipient reaction on the baddeleyitequartz interface was observed. While $a \mathrm{SiO}_{2}$ in the UK granites may have varied from the adamellites to the alkali feldspar granites, the ubiquitous presence of quartz 
may have meant that the activity was always close to unity. Perhaps the crystallization of baddeleyite was a result of local metastability.

ii. Calcium activity. In a study of zircon-bearing veins in a harzburgite xenolith from a kimberlite, Dawson et al. (2001) proposed that zircon was an early precipitate from the melt but, after a desilication reaction, was replaced by baddeleyite. The magma was then $\mathrm{Ca}-\mathrm{Ti}$ metasomatized, and zirconolite formed. Carlier and Lorand (2008) noted in lamprophyric melts of the south Peruvian potassic province the crystallization sequence $\mathrm{Zr}$-rich titanite $\rightarrow$ perrierite $\rightarrow$ zirconolite + baddeleyite and ascribed the changes to decreasing Ca activity. In a series of experiments, Lewerentz et al. (2019) reacted unaltered zircon with $\mathrm{H}_{2} \mathrm{O}-\mathrm{CaCl}_{2}$ and $\mathrm{H}_{2} \mathrm{O}$ $\mathrm{Ca}(\mathrm{OH})_{2}$ fluids. They found that baddeleyite replaced the zircon only when Ca saturated the system, lowering the $a \mathrm{SiO}_{2}$ to $<1$. However, they noted that in natural rocks, baddeleyite can form in the interiors of zircon in contact with quartz, which they attributed to local, small-scale metastability. The average $\mathrm{CaO}$ abundances in the granites are type $1=1.78 \mathrm{wt} \%$; type $2=$ $1.23 \mathrm{wt} \%$; and type $3=0.43 \mathrm{wt} \%$. If the concentrations can be taken as reasonable estimates of Ca activity, this could explain the presence of zirconolite in types 1 and 2 but its absence in type 3, peralkaline granites.

Dalyite has been recorded as an accessory mineral in a range of rocks, including peralkaline granites and syenites and highly potassic rocks such as lamproites and lamprophyres. Harris et al. (1982) reported dalyite in a peralkaline granite block from Ascension Island. In the Strange Lake peralkaline granite complex, Quebec-Labrador, dalyite nucleated heterogeneously on older zircon crystals (Salvi and Williams-Jones, 1995). Jeffery et al. (2016) reported dalyite in syenitic ejecta of the Caldeira-Castelinho Ignimbrite Formation of Terceira, Azores, where it is interstitial, (partly) filling void spaces, as shown by some of the Ailsa Craig crystals (Fig. 13). Dalyite crystallization is thus favored in peralkaline silica-oversaturated conditions, as in the Ailsa Craig sample, and probably in melts with a high chemical potential of $\mathrm{K}_{2} \mathrm{O}\left(\mu \mathrm{K}_{2} \mathrm{O}\right.$; Marks et al., 2011; Jeffery et al., 2016). In the Ailsa Craig sample studied, there is no obvious crystallization sequence or transition among eudialyte, dalyite, or zircon based on texture; all appear as late-stage.

Eudialyte-group minerals are recorded most frequently in strongly silica-undersaturated alkaline rocks, such as agpaitic nepheline syenites and urtites. However, it is also known from alkaline granites and associated pegmatites; Estrade et al. (2018) list eight occurrences worldwide. Eudialyte was reported, for example, in a granite block from Ascension Island, where it occurs adjacent to dalyite with no evidence of reaction (Harris et al., 1982). Like dalyite, an unspecified eudialyte-group mineral totally or partially infills interstitial pore spaces in the Terceira syenites, but the two are not seen in contact (Jeffery et al., 2016). Among the UK Paleogene granites, eudialyte sensu lato was recorded in quartz syenites of the Carlingford complex, Northern Ireland, by Nockolds (1950), occurring in segregation areas with quartz, aegirine augite, and titanite. It was also found in crushes of the Rockall peralkaline granite (Sabine, 1960).

According to Sørensen (1997), the main factors controlling the crystallization of eudialyte-group minerals in a melt are its peralkalinity and high $\mathrm{Zr}$ and volatile contents, mainly $\mathrm{F}, \mathrm{Cl}$, and $\mathrm{H}_{2} \mathrm{O}$. Noting the high $\mathrm{Cl}$ abundances in eudialytegroup minerals, Estrade et al. (2018) specified that high $\mathrm{Cl}$ contents in the melt are a critical parameter for the crystallization of eudialyte in peralkaline granites.

\section{Summary}

This study documents the zirconium mineral sequence in UK Paleogene granites, types 1,2 , and 3, from early magmatic (baddeleyite $\rightarrow$ zirconolite $\rightarrow$ zircon) through latemagmatic to hydrothermal zircon. In the Ailsa Craig granite, all the Zr-bearing phases, dalyite, eudialyte, hydrothermal zircon, probable lemoynite, and $\mathrm{Zr}$-aegirine, are late-stage phases with no textural evidence for a definitive sequence.

The more strongly peralkaline Ailsa Craig microgranite contains a REE+Y-rich, Ca-poor eudialyte-group mineral and dalyite, the first documented occurrence in the United Kingdom. A late-stage incompatible-element-enriched hydrous zircon and a Zr-bearing fibrous mineral, probable lemoynite, were identified.

Zirconolite in the Grigadale Granophyre and Granophyre Centre 2 from Ardnamurchan and the Glamaig Granite from Skye Western Red Hills Centre are exceptionally REE+Yrich with $\mathrm{Y}$ dominant.

Data availability. All data are provided in the tables and in the Supplement.

Supplement. The supplement related to this article is available online at: https://doi.org/10.5194/ejm-33-537-2021-supplement.

Author contributions. RM obtained the samples. HEB examined and described petrographically the samples with SEM and analyzed the phases with electron microprobe. Both RM and HEB contributed to the text.

Competing interests. The contact author has declared that neither they nor their co-author has any competing interests.

Disclaimer. Any use of trade, product, or firm names is for descriptive purposes only and does not imply endorsement by the 
United States government.

Publisher's note: Copernicus Publications remains neutral with regard to jurisdictional claims in published maps and institutional affiliations.

Acknowledgements. We warmly thank Ian Meighan and Chris Wheatley (British Geological Survey) for provision of samples. Marc D. Norman (Australian National University) and Reto Gieré (University of Pennsylvania) graciously supplied needed references. We thank reviewers Nora K. Foley, Chris Harris, Ryan J. McAleer, Silvio R. F. Vlach, and Leone Melluso for their helpful and constructive comments on an earlier version of this paper. We also thank Mingqian Wu and an anonymous reviewer for their very helpful and insightful comments and Rucheng Wang for editorial handling.

Review statement. This paper was edited by Rucheng Wang and reviewed by Mingqian $\mathrm{Wu}$ and one anonymous referee.

\section{References}

Aleinikoff, J. N., Schenck, W. S., Plank, M. O., Srogi, L., Fanning, C. M., Kamo, S. L., and Bosbyshell, H.: Deciphering igneous and metamorphic events in high-grade rocks of the Wilmington Complex, Delaware: Morphology, cathodoluminescence and backscattered electron zoning, and SHRIMP U-Pb geochronology of zircon and monazite, Geol. Soc. Am. Bull., 118, 39-64, https://doi.10.1130/B25659.1, 2006.

Andersen, T., Erambert, M., Larsen, A. O., and Selbekk, R. S.: Petrology of nepheline syenite pegmatites in the Oslo Rift, Norway: $\mathrm{Zr}$ and $\mathrm{Ti}$ mineral assemblages in miaskitic and agpaitic pegmatites in the Larvik Plutonic Complex, Mineralogia, 44, 6198, https://doi.org/10.2478/mipo-2013-0007, 2013.

Anthony, J. W., Bideaux, R. A., Bladh, K. W., and Nichols, M. C.: Handbook of Mineralogy, Silica, Silicates Volume II, available at: http://www.handbookofmineralogy.org/pdfs/lemoynite. pdf (last access: 10 April 2020), 1995.

Armstrong, J. T.: CITZAF: A package of correction programs for the quantitative electron microbeam X-ray analysis of thick polished materials, thin films, and particles, Microb. Anal., 4, 177200, 1995

Arzamastsev, A. A., Belyatsky, B. V., and Arzamastseva, L. V.: Agpaitic magmatism in the northeastern Baltic Shield: a study of the Niva intrusion, Kola Peninsula, Russia, Lithos, 51, 27-46, https://doi.org/10.1016/S0024-4937(99)00073-0, 2000.

Atanasova, P., Krause, J., Möckel, R., Osbahr, I., and Gutzmer, J.: Electron probe microanalysis of REE in eudialyte group minerals: challenges and solutions, Microsc. Microanal., 21, 10961113, https://doi.10.1017/S1431927615000720, 2015.

Atencio, D., Andrade, M. B., Christy, A. G., Gieré, R., and Kartashov, P. M.: The pyrochlore supergroup of minerals: nomenclature, Can. Mineral., 48, 673-698, https://doi.org/10.3749/canmin.48.3.673, 2010.

Back, M. E.: Fleischer's Glossary of Mineral Species 2018, Mineralogical Record, Tucson, AZ, USA, 410 pp., 2018.
Barkov, A. Y., Pakhomovskii, Y. A., and Menshikov, Y.P.: Baddeleyite: new occurrences from two mafic-ultramafic layered intrusions, Russia, Mineral. Mag., 59, 349-353, https://doi.org/10.1180/minmag.1995.059.395.18, 1995.

Bayliss, P., Mazzi, F., Munno, R., and White, T. J.: Mineral nomenclature: zirconolite, Mineral. Mag., 53, 565-569, https://doi.org/10.1180/minmag.1989.053.373.07, 1989.

Bell, J. D.: Granites and associated rocks of the eastern part of the Western Redhills Complex, Isle of Skye, T. RSE Earth, 66, 307343, https://doi.org/10.1017/S0080456800023632, 1966.

Bell, J. D.: Acid intrusions, in: Igneous Rocks of the British Isles, edited by: Sutherland, D. S., J. Wiley and Sons, Ltd., Chichester, West Sussex, UK, 427-440, 1982.

Birkett, T. C., Miller, R. R., Roberts, A. C., and Mariano, A. N.: Zirconium-bearing minerals of the Strange Lake Intrusive Complex, Quebec-Labrador, Can. Mineral., 30, 191-205, 1992.

Borst, A. M., Finch, A. A., Friis, H., Horsburgh, N.J., Gamaletsos, P. N., Goettlicher, J., Steininger, R., and Geraki, K.: Structural state of rare earth elements in eudialyte-group minerals, Mineral. Mag., 84, 19-34, https://doi.org/10.1180/mgm.2019.50, 2020.

Bulakh, A. G. and Petrov, T. G.: Chemical variability of eudialytegroup minerals and their sorting, Neues Jb. Miner. Monat., 2004, 127-144, https://doi.10.1127/0028-3649/2004/2004-0127, 2004.

Carlier, G. and Lorand, J.-P.: Zr-rich accessory minerals (titanite, perrierite, zirconolite, baddeleyite) record strong oxidation associated with magma mixing in the south Peruvian potassic province, Lithos, 104, 54-70, https://doi.org/10.1016/j.lithos.2007.11.008, 2008.

Chukanov, N. V., Pekov, I. V., and Rastsvetaeva, R. K.: Crystal chemistry, properties and synthesis of microporous silicates containing transition elements, Russ. Chem. Rev., 73, 205-223, https://doi.org/10.1070/RC2004v073n03ABEH000825, 2004.

Chukanov, N. V., Rastsvetaeva, R. K., Kruszewski, Ł., Aksenov, S. M., Rusakov, V. S., Britvin and S. N., and Vozchikova, S A.: Siudaite, $\mathrm{Na}_{8}\left(\mathrm{Mn}_{2}+2 \mathrm{Na}\right) \mathrm{Ca}_{6} \mathrm{Fe}_{3}^{3+} \mathrm{Zr}_{3} \mathrm{NbSi}_{25} \mathrm{O}_{74}(\mathrm{OH})_{2} \mathrm{Cl}$. $5 \mathrm{H}_{2} \mathrm{O}$ : a new eudialyte-group mineral from the Khibiny alkaline massif, Kola Peninsula, Phys. Chem. Miner., 45, 745-758, https://doi.org/10.1007/s00269-018-0959-9, 2018.

Coelho, A. A., Cheary, R. W., and Smith, K. L.: Analysis and structural determination of Nd-substituted zirconolite-4M, J. Solid State Chem., 129, 346-359, https://doi.org/10.1006/jssc.1996.7263, 1997.

Dawson, J. B., Hill, P. G., and Kinny, P. D.: Mineral chemistry of a zircon-bearing, composite, veined and metasomatised uppermantle peridotite xenolith from kimberlite, Contrib. Mineral Petr., 140, 720-733, https://doi.10.1007/s004000000216, 2001.

Deer, W. A., Howie, R. A., and Zussman, J.: Orthosilicates, Rockforming minerals, second edition, volume 1A, Longman, London, UK, 936 pp., https://doi.org/10.1002/gj.3350180308, 1982.

de Hoog, J. C. M. and van Bergen M. J.: Volatile-induced transport of HFSE, REE, Th and $U$ in arc magmas: evidence from zirconolite-bearing vesicles in potassic lavas of Lewotolo volcano (Indonesia), Contrib. Mineral. Petr., 139, 485-502, https://doi.org/10.1007/s004100000146, 2000.

Della Ventura, G., Bellatreccia, F., and Williams, C. T.: Zirconolite with significant $R E E Z \mathrm{ZNb}(\mathrm{Mn}, \mathrm{Fe}) \mathrm{O}_{7}$ from a xenolith of the Laacher See eruptive center, Eifel volcanic region, Germany, Can. Mineral., 38, 57-65, https://doi.org/10.2113/gscanmin.38.1.57, 2000. 
Duggan, M. B.: Zirconium-rich sodic pyroxenes in felsic volcanics from the Warrumbungle Volcano, Central New South Wales, Australia, Mineral. Mag., 52, 491-496, https://doi.10.1180/minmag.1988.052.367.07, 1988.

Emeleus, C. H. and Bell, B. R.: British regional geology: the Palaeogene volcanic districts of Scotland, 4th Edn, British Geological Survey, Keyworth, Nottingham, UK, 214 pp., 2005.

Estrade, G., Salvi, S., Béziat, D., Rakotovao, S., and Rakotondrazafy, R.: REE and HFSE mineralization in peralkaline granites of the Ambohimirahavavy alkaline complex, Ampasindava peninsula, Madagascar, J. Afr. Earth Sci., 94, 141-155, https://doi.org/10.1016/j.jafrearsci.2013.06.008, 2014.

Estrade, G., Salvi, S., and Béziat, D.: Crystallization and destabilization of eudialyte-group minerals in peralkaline granite and pegmatite: a case study from the Ambohimirahavavy complex, Madagascar, Mineral. Mag., 82, 375-399, https://doi.org/10.1180/minmag.2017.081.053, 2018.

Ferry, J. M.: Hydrothermal alteration of Tertiary igneous rocks from the Isle of Skye, northwest Scotland II. Granites, Contrib. Mineral. Petr., 91, 283-304, https://doi.org/10.1007/BF00413353, 1985.

Finch, R. J. and Hanchar, J. M.: Structure and chemistry of zircon and zircon-group minerals, in: Zircon, edited by: Hanchar, J. M. and Hoskin, P. W. O., Reviews in Mineralogy and Geochemistry, 53. Mineralogical Society of America, Washington DC, 1-25, https://doi.org/10.2113/0530001, 2003.

Fowler, M. B. and Williams, C. T.: Zirconolite from the Glen Dessarry syenite; a comparison with other Scottish zirconolites, Mineral. Mag., 50, 326-328, https://doi.org/10.1180/minmag.1986.050.356.21, 1986.

Gamble, J. A., Meighan, I. G., and McCormick, A. G.: The petrogenesis of Tertiary microgranites and granophyres from the Slieve Gullion Central Complex, NE Ireland, J. Geol. Soc. London, 149, 93-106, https://doi.org/10.1144/gsjgs.149.1.0093, 1992.

Gamble, J. A., Wysoczanski, R. J., and Meighan, I. G.: Constraints on the age of the British Tertiary Volcanic Province from ion microprobe U-Pb (SHRIMP) ages for acid igneous rocks from NE Ireland, J. Geol. Soc. London, 156, 291-299, https://doi.org/10.1144/gsjgs.156.2.0291, 1999.

Gieré, R., Williams, C. T., and Lumpkin, G. R.: Chemical characteristics of natural zirconolite, Schweiz. Miner. Petrogr., 78, 433459, 1998.

Govindaraju, K.: 1987 compilation report on Ailsa Craig granite AC-E with the participation of 128 GIT-IWG laboratories, Geostandard. Newslett., 11, 203-240, https://doi.org/10.1111/j.1751908X.1987.tb00029.x, 1987.

Harding, R. R.: Zr-rich pyroxenes and glauconitic minerals in the Tertiary alkali granite of Ailsa Craig, Scott. J. Geol., 19, 219227, https://doi.org/10.1144/sjg19020219, 1983.

Harding, R. R., Merriman, R. J., and Nancarrow, P. H. A.: A note on the occurrence of chevkinite, allanite, and zirkelite on St Kilda, Scotland, Mineral. Mag., 46, 445-448, https://doi.org/10.1180/minmag.1982.046.341.06, 1982.

Harley, S. L.: Mg-Al ytrrian zirconolite in a partially melted sapphirine granulite, Vestfold Hills, East Antarctica, Mineral. Mag., 58, 259-269, https://doi.org/10.1180/minmag.1994.058.391.08, 1994.

Harley, S. L. and Kelly, N. M.: Zircon tiny but timely, Elements, 3, 13-18, https://doi.org/10.2113/gselements.3.1.13, 2007.
Harris, C. and Rickard, R. S.: Rare-earth rich eudialyte and dalyite from a peralkaline granite dyke at Straumsvola, Dronning Maud Land, Antarctica, Can. Mineral., 25, 755-762, 1987.

Harris, C., Cresseym G., Bell, J. D., Atkins, F. B., and Beswetherick, S.: An occurrence of rare-earth-rich eudialyte from Ascension Island, South Atlantic, Mineral. Mag., 46, 421-425, https://doi.org/10.1180/minmag.1982.046.341.02, 1982.

Harrison, R. K., Stone, P., Cameron, I. B., Elliot, R. W., and Harding, R. R.: Geology, petrology and geochemistry of Ailsa Craig, Ayrshire, British Geological Survey Report, 16, 29 pp., 1987.

Harrison, T. M. and Watson, E. B.: The behavior of apatite during crustal anatexis: equilibrium and kinetic considerations, Geochim. Cosmochim. Ac., 48, 1467-1477, https://doi.org/10.1016/0016-7037(84)90403-4, 1984.

Hawkes, J. R., Merriman, R. J., Harding, R. R., and Darbyshire, D. B. F.: Rockall Island: new geological, petrological, chemical, and $\mathrm{Rb}-\mathrm{Sr}$ age data, Report of the Institute of Geological Sciences, 75/1, 11-52, 1975.

Heaman, I. M., LeCheminant, A. N., and Rainbird, R. H.: Nature and timing of Franklin igneous events, Canada: Implications for a Late Proterozoic mantle plume and the breakup of Laurentia, Earth Planet. Sc. Lett., 109, 117-131, https://doi.org/10.1016/0012-821X(92)90078-A, 1992.

Hoskin, P. W. O. and Schaltegger, U.: The composition of zircon and igneous and metamorphic petrogenesis, in: Zircon, edited by: Hanchar, J. M and Hoskin, P. W. O., Reviews in Mineralogy and Geochemistry, Mineralogical Society of America, Washington DC, 53, 27-62, https://doi.org/10.2113/0530027, 2003.

Huebner, J. S. and Woodruff, M. E.: Chemical compositions and critical evaluation of microprobe standards available from the Reston microprobe facility, U.S. Geological Survey Open File Report 85-718, 45 pp., https://doi.org/10.3133/ofr85718, 1985.

Huraiová, M., Hurai, V., and Konečný, P.: Finding of baddeleyite $\left(\mathrm{ZrO}_{2}\right)$ in basalt maar near Hajnáčka (southern Slovakia), Mineralia Slovaca, 43, 255-262, 2011 [in Slovak with English abstract].

Ibañez-Mejia, M. and Tissot, F. L.: Extreme Zr stable isotope fractionation during magmatic fractional crystallization, Sci. Adv., 5, eaax8648, https://doi.org/10.1126/sciadv.aax8648, 2019.

Jeffery, A. J., Gertisser, R., Jackson, R. A., O'Driscoll, B. O., and Kronz, A.: On the compositional variability of dalyite, $\mathrm{K}_{2} \mathrm{ZrSi}_{6} \mathrm{O}_{15}$ : a new occurrence from Terceira, Azores, Mineral. Mag., 80, 547-565, https://doi.org/10.1180/minmag.2016.080.018, 2016.

Johnsen, O. and Gault, R. A.: Chemical variation in eudialyte, Neues Jb. Miner. Abh., 171, 215-237, 1997.

Johnsen, O. and Grice, J. D.: The crystal chemistry of the eudialyte group, Can. Mineral., 37, 865-891, 1999.

Johnsen, O., Grice, J. D., and Gault, R. A.: Oneillite; a new Cadeficient and $R E E$-rich member of the eudialyte group from Mont Saint-Hilaire, Quebec, Canada, Can. Mineral., 37, 1295-1301, 1999.

Johnsen, O., Ferraris, G., Gault, R. A., Grice, J. D., Kampf, A. R., and Pekov, I. V.: The nomenclature of eudialyte-group minerals, Can. Mineral., 41, 785-794, https://doi.org/10.2113/gscanmin.41.3.785, 2003.

Jones, A. P. and Peckett, A.: Zirconium-bearing aegirines from Motzfeldt, south Greenland, Contrib. Mineral. Petr., 75, 251255, 1980. 
Karup-Møller, S. and Rose-Hansen, J.: New data on eudialyte decomposition minerals from kakortokites and associated pegmatites of the Ilíimaussaq complex, South Greenland, Bulletin of the Geological Society of Greenland, 61, 47-70, 2013.

Kynicky J., Chakmouradian A. R., Xu C., Krmicek L., and Galiova M.: Distribution and evolution of zirconium mineralization in peralkaline granites and associated pegmatites of the Khan Bogd complex, southern Mongolia, Can. Mineral., 49, 947-965, https://doi.org/10.3749/canmin.49.4.947, 2011.

Lewerentz, A., Harlov, D. E., Scherstén, A., and Whitehouse, M. J.: Baddeleyite formation in zircon by Ca-bearing fluids in silica-saturated systems in nature and experiment: resetting of the U-Pb geochronometer, Contrib. Mineral. Petr., 174, 1-25, https://doi.org/10.1007/s00410-019-1600-8, 2019.

Liu, F., Gerdes, A., Liou, J., and Liu, P.: Unique coesitebearing zircon from allanite-bearing gneisses: $\mathrm{U}-\mathrm{Pb}, \mathrm{REE}$ and Lu-Hf properties and implications for the evolution of the Sulu UHP terrane, China, Eur. J. Mineral., 21, 1225-1250, https://doi.org/10.1127/0935-1221/2009/0021-1965, 2009.

Lumpkin, G. R.: Physical and chemical characteristics of baddeleyite (monoclinic zirconia) in natural environments: an overview and case study, J. Nucl. Mater., 274, 206-217, 1999.

Macdonald, R., Bagiński, B., Dzierżanowski, P., Fettes, D. J., and Upton, B. G. J.: Chevkinite-group minerals in UK Palaeogene granites: underestimated REE-bearing accessory phases, Can. Mineral., 51, 333-347, https://doi.org/10.3749/canmin.51.2.333, 2013a.

Macdonald, R., Bagiński, B., Dzierżanowski, P., and Jokubauskas, P.: Apatite supergroup minerals in UK Palaeogene granites: composition and relationship to host-rock composition, Eur. J. Mineral., 25, 461-471, https://doi.org/10.1127/09351221/2013/0025-2291, 2013 b.

Marks, M. A. W., Hettmann, K., Schilling, J., Frost, R. R., and Markl, G.: The mineralogical diversity of alkaline igneous rocks: critical factors for the transition from $\mathrm{mi}-$ askitic to agpaitic assemblages, J. Petrol., 52, 439-455, https://doi.org/10.1093/petrology/egq086, 2011.

Mazzi, F. and Munno, R.: Calciobetafite (new mineral of the pyrochlore group) and related minerals from Campi Flegrei, Italy; crystal structures of polymignyte and zirkelite; comparison with pyrochlore and zirconolite, Am. Mineral., 68, 262-276, 1983.

McDonald, A. M. and Chao, G. Y.: Natrolemoynite, a new hydrated sodium zirconosilicate from Mont Saint-Hilaire, Quebec: Description and structure determination, Can. Mineral., 39, 12951306, 2001.

McDonald, A. M., Tarassoff, P., and Chao, G. Y.: Hogarthite,(Na, $\mathrm{K})_{2} \mathrm{CaTi}_{2} \mathrm{Si}_{10} \mathrm{O}_{26} \cdot 8 \mathrm{H}_{2} \mathrm{O}$, a new member of the lemoynite group from Mont Saint-Hilaire, Quebec: Characterization, crystalstructure determination, and origin, Can. Mineral., 53, 13-30, https://doi.org/10.3749/canmin.1400079, 2015.

McDonough, W. F. and Sun, S. S.: The composition of the Earth, Chem. Geol., 120, 223-253, 1995.

Melluso, L., De'Gennaro, R., Fedele, L., Franciosi, L., and Morra, V.: Evidence of crystallization in residual, Cl-Frich, agpaitic, trachyphonolitic magmas and primitive $\mathrm{Mg}$ rich basalt-trachyphonolite interaction in the lava domes of the Phlegrean Fields (Italy), Geol. Mag., 149, 532-550, https://doi.org/10.1017/S0016756811000902, 2012.
Mindat: Dalyite locality list, available at: https://www.mindat.org/ min-1214.html, last access: 20 May 2020.

Mitchell, R. H. and Liferovich, R. P.: Subsolidus deuteric/hydrothermal alteration of eudialyte in lujavrite from the Pilansberg alkaline complex, South Africa, Lithos, 91, 352-372, https://doi.org/10.1016/j.lithos.2006.03.025, 2006.

Morimoto, N.: Nomenclature of pyroxenes, Can. Mineral., 27, 143$156,1989$.

Murad, E.: Mineralogy of aegirine from Låven Island, Langesundfjorden, southern Norway, Norw. J. Geol., 86, 435-438, 2006.

Nockolds, S. R.: On the occurrence of neptunite and eudialyte in quartz-bearing syenites from Barnavave, Carlingford, Ireland, Mineral. Mag., 29, 27-33, 1950.

Norman, M. D. and Nemchin, A. A.: A 4.2 billion year old impact basin on the Moon: $\mathrm{U}-\mathrm{Pb}$ dating of zirconolite and apatite in lunar melt rock 67955, Earth Planet. Sc. Lett., 388, 387-398, https://doi.org/10.1016/j.epsl.2013.11.040, 2014.

Paterson, B. A., Stephens, W. E., Rogers, G., Williams, I. S., Hinton, R. W., and Herd, D. A.: The nature of zircon inheritance in two granite plutons, T. RSE Earth, 83, 459-471, 1992.

Perrault, G., Semenov, E. I., Bikova, A. V., and Capitonova, T. A.: La lemoynite, un nouveau silicate hydrate de zirconium et de sodium de St. Hilaire, Québec, Can. Mineral., 9, 585-596, 1969 [in French with English abstract].

Piccoli, P. M. and Candela, P. A.: Apatite in igneous systems, in: Phosphates-Geochemical, Geobiological, and Materials Importance, edited by: Kohn, M. J., Rakovan, J., and Hughes, J. M., Reviews of Mineralogy and Geochemistry 48, Mineralogical Society of America, Washington, DC, 255-292, 2002.

Piilonen, P. C., McDonald, A. M., and Lalonde, A. E.: The crystal chemistry of aegirine from Mont Saint-Hilaire, Quebec, Can. Mineral., 36, 779-791, 1998.

Potts, N. J., Tartèse, R., Anand, M., van Westrenen, W., Griffiths, A. A., Barrett, T. J., and Franchi, I. A.: Characterization of mesostasis regions in lunar basalts: Understanding late-stage melt evolution and its influence on apatite formation, Meteorit. Planet. Sci., 51, 1555-1575, https://doi.org/10.1111/maps.12681, 2016.

Preston, J., Hole, M., Bouch, J., and Still, J.: The occurrence of zirconian aegirine and calcic catapleiite $\left(\mathrm{CaZrSi}_{3} \mathrm{O}_{9} .2 \mathrm{H}_{2} \mathrm{O}\right)$ within a nepheline syenite, British Tertiary Igneous Province, Scott. J. Geol., 34, 173-180, 1998.

Rajesh, V. J., Yokoyama, K., Santosh, M., Arai, S., Oh, C. W., and Kim, S. W.: Zirconolite and baddeleyite in an ultramafic suite from southern India: Early Ordovician carbonatite-type melts associated with extensional collapse of the Gondwana crust, J. Geol., 114, 171-188, 2006.

Ramakrishnan, S. S., Gokhale, K. V. G. K., and Subbarao, E. C.: Solid solubility in the system zircon-hafnon, Mater. Res. Bull., 4, 323-327, 1969.

Ranløv, J. and Dymek, R. F.: Compositional zoning in hydrothermal aegirine from fenites in the Proterozoic Gardar Province, South Greenland, Eur. J. Mineral., 3, 837-854, https://doi.org/10.1127/ejm/3/5/0837, 1981.

Rastsvetaeva, R. K.: Structural mineralogy of the eudialyte group: A review, Crystallogr. Rep., 52, 47-64, https://doi.org/10.1134/S1063774507010063, 2007.

Rastsvetaeva, R. K., Chukanov, N. V., and Aksenov, S. M.: Eudialyte-Group Minerals: Crystal Chemistry, Properties, and 
Genesis, Lobachevsky State University of Nizhny Novgorod, Nizhny Novgorod, Russia, 229 pp., 2012 [in Russian].

Roedder, E.: Fluid inclusions, Mineralogical Society of America, Washington, DC, Rev. Mineral., 12, 644 pp., 1984.

Roedder, E. and Weiblen, P. W.: Petrology of some lithic fragments from Luna 20, Geochim. Cosmochim. Ac., 37, 1031-1052, 1973.

Sabine, P. A.: The geology of Rockall, North Atlantic, Bulletin of the Geological Survey of Great Britain, 16, 156-178, 1960.

Salvi, S. and Williams-Jones, A. E.: Zirconosilicate phase relations in the Strange Lake (Lac Brisson) pluton, Quebec-Labrador, Canada, Am. Mineral., 80, 1031-1040, 1995.

Salvioli-Mariani, E., Toscani, L., Bersani, D., Oddone, M., and Cancelliere, R.: Late veins of C3 carbonatite intrusion from Jacupiranga complex (Southern Brazil): fluid and melt inclusions and mineralogy, Mineral. Petrol., 104, 95-114, https://doi.org/10.1007/s00710-011-0179-1, 2012.

Sarangua, N., Watanabe, Y., Echigo, T., and Hoshino, M.: Chemical characteristics of zircon from Khaldzan Burgedei peralkaline complex, Western Mongolia, Minerals, 9, 1-20, https://doi.org/10.3390/min9010010, 2019.

Schärer, U., Berndt, J., and Deutsch, A.: The genesis of deep-mantle xenocrystic zircon and baddeleyite megacrysts (Mbuji-Mayi kimberlite): trace-element patterns, Eur. J. Mineral., 23, 241255, https://doi.org/10.1127/0935-1221/2011/0023-2088, 2011.

Schilling, J., Wu, F. -Y., McCammon, C., Wenzel, T., Marks, M. A. W., Pfaff, K., Jacob, D. E., and Markl, G.: The compositional variability of eudialyte-group minerals, Mineral. Mag., 75, 87115, https://doi.org/10.1180/minmag.2011.075.1.87, 2011.

Seddio, S., Jolliff, B., Korotev, R., and Carpenter, P.: Back-scattered Electron Tomography and X-Ray Microanalysis of Zirconolite in Lunar Granite 12032, 366-19, Microsc. Microanal., 17, 570-571, https://doi.org/10.1017/S1431927611003722, 2011.

Sheard, E. R., Williams-Jones, A. E., Heiligmann, M., Pederson, C., and Trueman, D. I.: Controls on the concentration of zirconium, niobium, and the rare-earth-elements in the Thor Lake Rare Metal Deposit, Northwest Territories, Canada, Econ. Geol., 107, 81-104, https://doi.org/10.2113/econgeo.107.1.81, 2012.

Shearer, C. K. and Larsen, L. M.: Sector-zoned aegirine from the Ilimaussaq alkaline intrusion, South Greenland: Implications for trace-element behavior in pyroxene, Am. Mineral., 79, 340-352, 1994.

Smith, K. L. and Lumpkin, G. R.: Structural features of zirconolite, hollandite and perovskite, the major wastebearing phases in Synroc, in: Defects and Processes in the Solid State: Geosciences Applications, edited by: Boland, J. N. and Fitz-Gerald, J. D., Elsevier, NY, 401-422, 1993.

Sørensen, H.: The agpaitic rocks - an overview, Mineral. Mag., 61, 417-427, 1997.

Speer, J. A.: Zircon, in: Orthosilicates Reviews in Mineralogy, 2nd Edn., edited by: Ribbe, P. H., Mineralogical Society of America, Washington, DC, 67-112, 1982.

Speer, J. A. and Cooper, B. J.: Crystal structure of synthetic hafnon, $\mathrm{HfSiO}_{4}$, comparison with zircon and the actinide orthosilicates, Am. Mineral., 67, 804-808, 1982.

Thompson, R. N.: Tertiary granites and associated rocks of the Marsco area, Isle of Skye, Q. J. Geol. Soc. London, 124, 349385, 1969.
Thompson, R. N.: Thermal aspects of the origin of Hebridean Tertiary acid magmas. II. Experimental melting behaviour of granites at 1 kbar $P_{\mathrm{H} 2 \mathrm{O}}$, Mineral. Mag., 47, 111-121, 1983.

Tropper, P., Harlov, D., Krenn, E., Finger, F., Rhede, D., and Bernhard, F.: Zr-bearing minerals as indicators for the polymetamorphic evolution of the eastern, lower Austroalpine nappes (Stubenberg Granite contact aureole, Styria, Eastern Alps, Austria), Lithos, 95, 72-86, https://doi.org/10.1016/j.lithos.2006.07.008, 2007.

Valley, P. M., Fisher, C. M., Hanchar, J. M., Lam, R., and Tubrett, M.: Hafnium isotopes in zircon: A tracer of fluid-rock interaction during magnetite-apatite ("Kiruna-type") mineralization, Chem. Geol., 275, 208-220, 2010.

Van Tassel, R. and Hey, M. H.: Dalyite, a new potassium zirconium silicate, from Ascension Island, Atlantic, Mineral. Mag., 29, 850-857, 1952.

Wark, D. A., Reid, A. F., Lovering, J. F., and El Goresy, A.: Zirconolite (versus zirkelite) in lunar rocks, in: Proceedings of the 4th Lunar Science Conference, Lunar Science Institute, Houston, TX, 5-8 March 1973, 764-766, 1973.

White, T. J.: The microstructure and microchemistry of synthetic zirconolite, zirkelite and related phases, Am. Mineral., 69, 1156$1172,1984$.

Williams, C. T.: Uranium-enriched minerals in mesostasis areas of the Rhum layered pluton, Contrib. Mineral. Petr., 66, 29-39, 1978.

Williams, C. T.: The occurrence of niobian zirconolite, pyrochlore and baddeleyite in the Kovdor carbonatite complex, Kola Peninsula, Russia, Mineral. Mag., 60, 639-646, 1996.

Williams, C. T. and Gieré, R.: Zirconolite: a review of localities worldwide, and a compilation of its chemical compositions, Bulletin of the Natural History Museum London (Geology), 52, 124, 1996.

Wu, B., Wang, R. C., Yang, J. H., Wu, F. Y., Zhang, W. L., Gu, X. P., and Zhang, A. C.: Wadeite $\left(\mathrm{K}_{2} \mathrm{ZrSi}_{3} \mathrm{O}_{9}\right)$, an alkali-zirconosilicate from the Saima agpaitic rocks in northeastern China: Its origin and response to multistage activities of alkaline fluids, Lithos, 224, 126-142, https://doi.org/10.1016/j.lithos.2015.02.008, 2015.

Wu, B., Wang, R. C., Yang, J. H., Wu, F. Y., Zhang, W. L., Gu, X. P., and Zhang, A. C.: Zr and REE mineralization in sodic lujavrite from the Saima alkaline complex, northeastern China: A mineralogical study and comparison with potassic rocks, Lithos, 262, 232-246, https://doi.org/10.1016/j.lithos.2016.07.013, 2016.

Young, S. R., Hawkes, J. R., Merriman, R. J., and Styler, M. T.: Bazirite, $\mathrm{BaZrSi}_{3} \mathrm{O}_{9}$, a new mineral from Rockall Island, Inverness-shire, Scotland, Mineral. Mag., 42, 35-40, 1978.

Zakrzewski, M. A., Lustenhouwer, W. J., Nugteren, H. J., and Williams, C. T.: Rare-earth minerals yttrian zirconolite and allanite-(Ce) and associated minerals from Koberg mine, Bergslagen, Sweden, Mineral. Mag., 56, 27-35, 1992.

Zhang, S. H., Zhao, Y., Li, Q. L., Hu, Z. C., and Chen, Z. Y.: First identification of baddeleyite related/linked to contact metamorphism from carbonatites in the world's largest REE deposit, Bayan Obo in North China Craton, Lithos, 284, 654-665, 2017.

Zhao, W. W., Zhou, M. F., and Chen, W. T.: Growth of hydrothermal baddeleyite and zircon in different stages of skarnization, Am. Mineral., 101, 2689-2700, 2016. 